\title{
ON THE SYSTEMATICS AND ORIGIN OF THE GENERIC GROUP OXYPTILUS ZELLER (LeP. AluCitidae)
}

BY

STANISEAW ADAMCZEWSKI

Polish Museum of Zoology, Warsaw

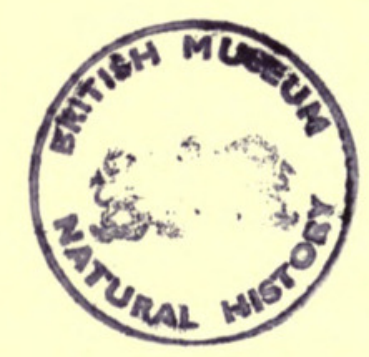

Pp. 30I-388; Pls. 9-20

BULLETIN OF

THE BRITISH MUSEUM (NATURAL HISTORY) ENTOMOLOGY Vol. I No. 5

LONDON : I95I 
THE BULlEtiN OF THE BRItish MUSEUM (NATURAL HISTORY), instituted in 1949 , is to be issued in five series, corresponding to the Departments of the Museum.

Parts will appear at irregular intervals as they become ready. Volumes will contain about three or four hundred pages, and will not necessarily be completed within one calendar year.

This paper is Vol. I, No. 5, of the Entomological series.

PRINTED BY ORDER OF THE TRUSTEES OF THE BRITISH MUSEUM 


\section{ON THE SYSTEMATICS AND ORIGIN OF THE GENERIC GROUP OXYPTILUS ZELLER (LEP., ALUCITIDAE)}

By STANISEAW ADÄMCZEWSKI

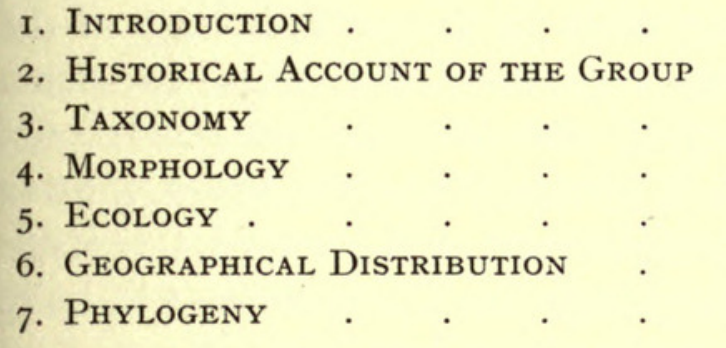

\section{CONTENTS}

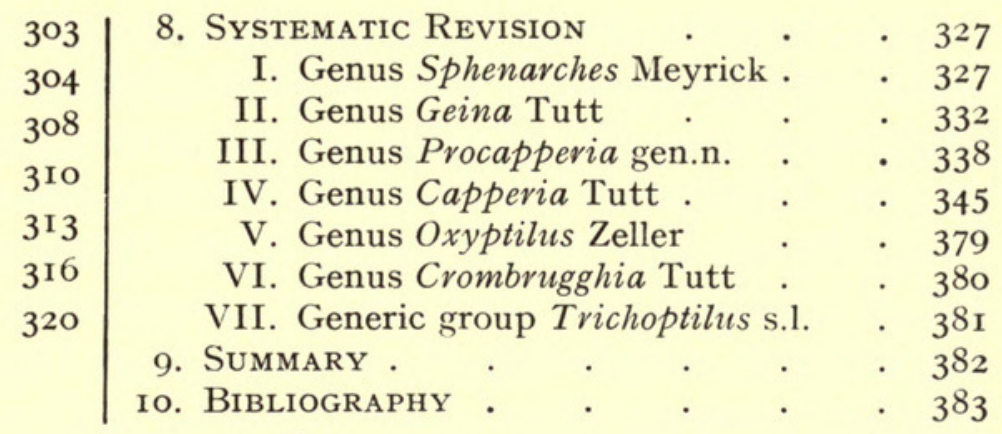

\section{INTRODUCTION}

THIS work was originally submitted for publication in the Annales Musei Zoologici Polonici in Warsaw, and was actually being printed in I939 when a German raid destroyed the printing-house and with it my manuscript and the proofs. Fortunately drawings and notes escaped destruction, and I have therefore been able to reconstruct my work, though in a somewhat altered form. I have deliberately retained therein for documentary reasons data relating to material no longer in existence, particularly the information relating to the location of some type specimens in the Polish Museum of Zoology. The entomological collections of that institution were completely destroyed by the Germans a few years later (I944), including all the types mentioned below. Other material, including type specimens, was located in the museums of Bremen and Budapest, and I have no information as to whether this has survived the ravages of war.

The results have been amplified as a consequence of the examination of supplementary material during my stay in London in I947. Thus I have added two species-Capperia tamsi sp.n. and Procapperia linariae Chrétien-which were not previously included. Many new data concerning the geographical distribution of other species have been added. The value of the results achieved has been greatly enhanced through my having the opportunity of reviewing all the available types in the British Museum (Natural History).

The section dealing with the phylogeny of the group, formerly based mainly on analyses of morphology, geographical distribution, and ecological data, has been modified as a result of increased knowledge gained from a close study of the works of Wegener, Du Toit, Zeuner, and Jeannel. However, the main aim of these investigations has remained the systematic revision of the group. The phylogenetic studies are only provisionally sketched to supplement the taxonomic part of the work. 
Much more material than that at present available to me, and more biological as well as genetic investigations, are necessary before an adequate phylogenetic treatment of the group can be attempted as a separate subject.

The systematic part of this work is based mainly on the arranged material of the generic group in various European museums, but also on material of my own collecting.

The systematics of the group have been entirely revised, including the taxonomic values of the generic and trivial names, and in the course of the work it has been found necessary to resurrect some synonyms and to distinguish some new genera and species.

The classification of the group has been based mainly on the morphology of the copulatory apparatus. The whole Oxyptilus complex (sensu Zeller, I84I) has been disposed within the compass of ten genera, including one new and six resurrected genera. Of these it has been possible to work out in detail only part, viz. Capperia Tutt, Procapperia gen.n., Geina Tutt, Sphenarches Meyrick, and in part Oxyptilus Zeller and Crombrugghia Tutt. The remainder (generic group Trichoptilus s.l.) have not yet been adequately examined, though they are recognized as forming a part of this particular complex, and will, it is hoped, be worked out in detail later.

A novelty in this particular study is the attempt to test the value of the classification based on morphology by taking into account the biosystematic features of the systematic units drawn from their ecology, geographical distribution, and phylogeny. Unfortunately I have so far had no opportunity to verify my conclusions by a study of the ontogeny and genetics of the species examined.

Here I would like to express my thanks to the Trustees of the British Museum and to Mr. N. D. Riley, the Keeper of the Department of Entomology in the British Museum (Natural History), for allowing me the opportunity of completing this work in that institution, and for their help in the matter of publication. I am very grateful to Mr. W. H. T. Tams, who has charge of the Heterocera in the British Museum, and to Mr. T. Bainbrigge Fletcher, of Stroud, a recognized authority on the Alucitidae, who by their great help enabled me to complete my manuscript, removing from my path all the difficulties I encountered in this work. The photographs on Plates X, XI, and XII were made by Mr. W. H. T. Tams.

\section{HISTORICAL ACCOUNT OF THE GROUP}

The group of species which is the subject of this work has always been a fascinating field of study for the systematic worker. It was established by Zeller in I84I, and he described the majority of the central European species belonging here. However, the group has not been thoroughly revised during the past hundred years.

Before Zeller's publications the names of no more than three species were involved:

I. Alucita didactyla Linnaeus, I758.

2. Alucita chrysodactyla Denis et Schiffermüller, I775.

3. Alucita trichodactyla Denis et Schiffermüller, I775.

These three species are the representatives in our present classification of the three genera: Geina Tutt, Oxyptilus Zeller, and Capperia Tutt. Linnaeus in I76r recorded 
his didactyla as feeding 'Geo rivali'. De Geer in I77I described the biology of the same species, living on Geum rivale. Hübner ${ }^{1}$ in his Beiträge (I790) published some remarks on the name 'trichodactyla des Syst. Verz.' and a few years later in the Sammlung $(\mathrm{I} 800-\mathrm{I} 9)^{\mathrm{I}}$ he published the coloured figures of two forms under the same name trichodactyla. However, we now can see that his figure I8 only is trichodactyla, figure 9 being chrysodactyla. The figures of the caterpillar and pupa of trichodactyla, together with the food-plant Leonurus cardiaca showing the characteristic damage, published by Hübner in his Geschichte (I8I8-22) confirm us in the conclusion that Hübner was figuring the species described later by Stange (I882) as leonuri. Laspeyres in I805 expressed doubt whether 'didactyla Linn.' and 'didactyla Schiff.' were the same species. Charpentier, after comparing the original specimens in Schiffermüller's collection, stated in I82I that 'chrysodactyla Schiff.' and 'didactyla Schiff.' were identical and that they were very similar to 'trichodactyla Schiff.', and that those forms were figured by Hübner as trichodactyla (figs. 9 and I8). It is true that Hübner thought that the three forms belonged to the same species and clearly synonymized them in the Verzeichniss (I826) under the name trichodactyla. So far as we can judge from the data recorded in the literature, the true didactyla L. did not exist in Schiffermüller's collection, but only a species of Oxyptilus similar to chrysodactyla, pilosellae, or ericetorum, which at that time was undescribed and was later distinguished by Zeller. Treitschke (I833), in describing the species living on Leonurus, chose from the so-called synonyms the oldest name 'didactyla L.', overlooking the fact that Linnaeus had defined that species as living on Geum rivale and not on Leonurus. Also Duponchel in 1838 used the name didactylus for the only species of the group under review known to him. Later (I845) Duponchel excluded from didactylus as a different species 'chrysodactylus W.V.', giving quite correctly the following synonymy: 'hieracii Zell. = trichodactyla $\mathrm{Hb}$. fig. $9=$ chrysodactyla W.V.' In I839 Zeller for the first time became interested in this group and distinguished three species: (I) Without a spot on the hind wings (Pterophorus paludum), (2) with a spot in the middle of the third feather of the secondaries (Pterophorus tristis), and (3) Pterophorus didactylus Linn. Under the last name Zeller mixed three species: (a) genuine didactylus L. bred by De Geer on Geum, (b) trichodactylus Denis et Schiffermüller living on Leonurus (data taken from Treitschke), and (c) his own specimens bred on Hieracium umbellatum, and later described by him as Oxyptilus hieracii. In I84I Zeller divided the genus Pterophorus into groups. One of them is the Oxyptilus group, which contains five species: tristis Zeller, pilosellae Zeller, obscurus Zeller (afterwards synonymized with parvidactylus Haworth), hieracii Zeller, and trichodactylus Hübner. Zeller was very careful not to continue Treitschke's (I833) and Duponchel's (I838) synonymy: 'trichodactylus $\mathrm{Hbn}$. = didactylus L.' Therefore, not knowing (on his own showing) didactyla Linn., to which he did not allow separate status, he only stressed the similarity of the description of didactyla and his hieracii; at the same time he mentioned that De Geer's description of the caterpillar showed the differences between hieracii and didactyla. Unfortunately, under the name 'trichodactylus Hb.' Zeller put the true didactyla L., as we can clearly see from his description, not knowing that in Schiffermüller's collection didactyla was not properly determined, and that both

I For dates of Hübner's publications vide Hemming, I937. 
Hübner's and Treitschke's synonymy of that species were also wrong. In the same publication Zeller discussed Schiffermüller's species, basing his views on specimens which have been recognized as identical with Schiffermüller's types in the Vienna collection. Zeller's studies resulted in the discovery that chrysodactyla D. \& Schiff. is the same as hieracii Zeller, and that trichodactyla D. \& Schiff. is synonymous with Oxyptilus obscurus Zeller var. $b$. As a pioneer expert Zeller showed himself to be remarkably competent and his opinions and notes are of the greatest value in helping us to arrive at a proper synonymy. In I847 Zeller gave descriptions of three new species from southern Europe: Oxyptilus distans, O. laetus, and O. marginellus. Zeller's most complete elaboration of that group was published in 1852 . There Zeller included in the genus Oxyptilus twelve species: kollari Stainton, tristis Zeller, distans Zeller, laetus Zeller, wahlbergi Zeller, caffer Zeller, pilosellae Zeller, hievacii Zeller, ericetorum Zeller, trichodactylus Hübner, obscurus Zeller, and marginellus Zeller. At the same time he included in the genus Aciptilia two species, paludum Zeller and siceliota Zeller, wrongly associated by later systematists with the genus Trichoptilus, together with Zeller's Oxyptilus wahlbergi. Although in Zeller's genus Oxyptilus we see species belonging to six genera (see Systematic Revision, pp. 327 et seq.), we must credit Zeller with correctly separating his own species paludum and siceliota from wahlbergi. From the species included by Zeller in Oxyptilus only wahlbergi and caffer were removed by later authors to the newly described genera Trichoptilus and Sphenarches, and once again trichodactylus Hübner was wrongly treated as a synonym of didactyla L. The genus Trichoptilus was described by Walsingham in I880 for the North American species pygmaeus Walsingham. Later the species siceliota Zeller and paludum Zeller (vide Meyrick, I886), of completely different morphology, were wrongly added to this genus. The genus Sphenarches was described by Meyrick (I886) for Zeller's caffer. Walsingham (I887) wrongly stated that the North American species periscelidactylus Fitch also belonged here (vide genus Geina Tutt). This systematic arrangement has been maintained right up to the present day. Zeller's systematics, which made a great step forward a hundred years ago, are far from perfect. Zeller united in one genus various forms very far apart from each other. To-day species known to Zeller as Oxyptilus are classified in six different genera, and this position would have been attained long ago had not the recognized authorities on the so-called Microlepidoptera-Staudinger and Rebel on the Continent, and Meyrick in England, with the majority of their colleagues and most of the collectors, remained so conservative and adverse to any deeper investigation into the systematics of this group. I must, however, draw particular attention to the work of one student of the Lepidoptera, namely, J. W. Tutt. In volume v of his remarkable work A Natural History of the British Lepidoptera (I907) Tutt elaborated a reformed classification of the British Alucitidae, based not only on the external morphology of the imagines, but on the synthesis of all the available features of the imagines, together with the morphological and ecological characteristics of the early stages. One may lay particular stress on Tutt's profound grasp of the taxonomy of this group, because other students, working on much richer material from a terrain far wider than Britain, have failed to appreciate the systematics of this group in their proper proportions. Tutt divided the species at that time included in Oxyptilus Zeller into the following genera: Oxyptilus 
Zeller, Crombrugghia Tutt, Geina Tutt, and Capperia Tutt. He created also a genus Buckleria Tutt for paludum Zeller, formerly wrongly placed in Trichoptilus Walsingham. For the same reasons Tutt created another new genus Stangeia for the south European species siceliota Zeller. Unfortunately Tutt did not describe some of his new genera and through lack of such descriptions they may be considered by some systematists as nomina nuda. On the other hand, when Tutt proposed a new genus for a particular species, he proposed a monotypic genus with a type and this is accepted by the majority of taxonomists. Tutt classified the European species known to him, then grouped in the two genera Oxyptilus Zeller and Trichoptilus Walsingham, in six genera, excluding Walsingham's genus Trichoptilus from the European fauna. Unfortunately Tutt's classification was not only rejected, but it met with criticism and disapproval. Meyrick (I9I3) synonymized all Tutt's genera. Barnes and Lindsey (I92I), in their Monograph of North American Plumes, criticized Tutt's systematics in a way that merely reflects discredit on themselves. Quite apart from that, they wrote: 'We follow Meyrick's synonymy. Geina Tutt is, of course, a synonym of Pterophorus. We are not familiar with the types of Capperia and Crombrugghia in nature but from Tutt's remarks we judge these genera to be of the same character as others of his, and therefore happily suppressed. We regard a genus as a systematic unit and not a biological division and feel that when it loses its value for classification it has lost the right to exist.' The scientist of to-day aims at a natural classification of living organisms, based on all the available data; the too-slavish adherence to the artificial systematics of the past century has brought taxonomy down to a level very low in the estimation of the scientific world. In fact, taxonomy should be the most important science, being the synthesis of all biological sciences. Barnes and Lindsey, as followers of the out-of-date systematic school of Rebel and Meyrick, fell into many errors. Their synonymy of families and genera is full of mistakes (compare with Fletcher's synonymy of Plumes, Fletcher, I93I). That same systematic outlook, based on a superficial review of the morphology of the imagines, resulted in the faulty interpretation of some of the data available in the American literature. McDunnough (I923, I927, I933) was able to make some satisfactory correstions of Barnes and Lindsey's mistakes owing to his more comprehensive knowledge of ecology. The synonymy of the North American Plumes proposed by Barnes and Lindsey seems to be so unnatural that a complete revision of that material is required, especially in connexion with the geographical distribution of the species. The failure of some museum systematists to appreciate the importance of biological data has led to many errors, particularly with regard to the geographical distribution of species, and, in consequence, further research based mainly on statements in literature has led to further mistakes.

To return to the group under discussion, its division into the three genera Oxyptilus Zeller, Trichoptilus Walsingham, and Sphenarches Meyrick, has undergone little change right up to the present day. The number of species recognized reached II2, nearly half of them described by Meyrick ( 47 species exclusive of synonyms), from all parts of the world. The new genus and species Megalorrhipida palaestinensis described by Amsel in I935 was synonymized as Trichoptilus defectalis Walker (Amsel, I940). However, as we shall see, the generic name Megalorrhipida will have to be reinstated. In my note (I939) I showed the necessity of keeping the generic name Capperia Tutt, 
and I described the differences between this genus and Oxyptilus Zeller. But it was not correct to synonymize the genera Capperia Tutt and Geina Tutt, which differ in every respect.

\section{TAXONOMY}

The generic group Oxyptilus (sensu lato) has been divided into three genera, Sphenarches Meyrick, Trichoptilus Walsingham, and Oxyptilus Zeller, but a further analysis of the whole group shows that these really comprise two entirely different groups. One is represented by the two genera Sphenarches Meyrick and Oxyptilus Zeller, and the other by Trichoptilus Walsingham.

A part of the first group is worked out in detail in this paper. This part, except for some newly described species, contains the species formerly reckoned as belonging to the genera Sphenarches Meyrick and Oxyptilus Zeller, and distributed below between the following six genera: Sphenarches Meyrick, Capperia Tutt, Procapperia gen.n., Geina Tutt, Oxyptilus Zeller, and Crombrugghia Tutt. The species belonging to Oxyptilus Zeller and Crombrugghia Tutt have been taken into account in a general way only because all my notes and drawings relating to these species were destroyed during the war. They will be especially revised in a separate publication. Further, the species belonging to the second group (Trichoptilus, sensu lato) are taken into account only as material for comparison, and will also need to be worked out in detail. For the time being I have divided the second group into four genera:-Megalorrhipida Amsel, Trichoptilus Walsingham, Stangeia Tutt, and Buckleria Tutt. The North American species of the second group probably belong not only to Trichoptilus Walsingham and Megalorrhipida Amsel, but also to genera not yet separately established. The detailed working out of these species is a matter for further investigations. In the present paper I use the generic and specific names in accordance with the following arrangement:

I, Genus Sphenarches Meyrick.

I. caffer Zeller-typus generis (= walkeri Walsingham).

2. anisodactylus Walker (= diffusalis Walker = synophrys Meyrick = ? chroesus Strand).

3. ontario McDunnough.

4. zanclistes Meyrick.

II. Genus Geina Tutt.

I. didactyla Linnaeus-typus generis (= brunneodactyla Millière).

2. kuldschaensis Rebel.

3. periscelidactyla Fitch.

4. tenuidactyla Fitch (= nigrociliatus Zeller = cygnus Barnes et Lindsey).

5. ,buscki McDunnough.

III. Genus Procapperia gen.n.

I. maculata Constant-typus generis.

2. linariae Chrétien.
3. anatolica Caradja.

4. croatica sp.n.

5. pelecyntes Meyrick.

IV. Genus Capperia Tutt.

I. britanniodactyla Gregson - typus generis (= heterodactyla Haworth; Tutt, Meyrick, nec Müller, Villers; = teucrii Jordan).

2. celeusi Frey (= intercisus Meyrick).

3. washbourni sp.n.

4. ningoris Walsingham.

5. evansi McDunnough.

6. trichodactyla Denis et Schiffermüller (= leonuri Stange $=$ affinis MüllerRutz).

7. fusca Hofmann.

8. fusca Hofmann n. forma marrubii.

9. tamsi sp.n.

Io. raptor Meyrick.

II. hellenica sp.n. 
12. lorana Fuchs.

13. marginella Zeller.

I4. zelleri sp.n.

I5. polonica sp.n.

16. maratonica sp.n.

I 7. fletcheri sp.n.

18. geodactyla Fuchs.

V. Genus Crombrugghia Tutt.

I. distans Zeller-typus generis.

2. laetus Zeller.

3. lantoscanus Millière.

4. tristis Zeller.
5. kollari Stainton.

VI. Genus Oxyptilus Zeller.

I. pilosellae Zeller-typus generis.

2. ericetorum Stainton (= ericetorum Zeller).

3. chrysodactylus Denis et Schiffermüller (= hievacii Zeller).

4. parvidactylus Haworth (= obscurus Zeller).

5. bohemanni Wallengren.

6. delavaricus Zeller.

7. hoffmannseggi Möschler.

Of the above-mentioned species I have not seen three, namely, geodactyla Fuchs, anatolica Caradja, and kuldschaensis Rebel. Until I have been able to obtain material of these species I cannot with certainty give them their proper systematic position, but judging from the available information I have provisionally given them places in my scheme. For example, judging from Fuchs's description (I903) I believe that geodactyla belongs to Capperia. It is possible that geodactyla is a synonym of Oxyptilus hoffmannseggi, a very little known species recorded also from the same locality in Armenia (Caradja, I920). Fuchs, in his description of geodactyla, says that this species is very similar to celeusi and we know how often celeusi is confused with hoffmannseggi. However, acting only on supposition, we cannot put geodactyla into the synonymy, the more so as Fuchs was a competent specialist in the Plumemoths.

Similarly, Rebel's description (I9I4) of Oxyptilus kuldschaensis indicates a close similarity to the very characteristic and distinct species Geina didactyla Linnaeus. For that reason I have put kuldschaensis in the genus Geina Tutt.

The easiest to settle was the question of anatolica. Amongst material from Asia Minor I found a species previously unknown to me belonging to the genus Procapperia. The origin of the specimens, and their agreement in some important features with Caradja's description, have induced me provisionally to determine them as anatolica. I have based my description on these specimens, and I hope that Caradja's type belongs to the same species.

The second part of the group Oxyptilus (sensu lato) is an evolutionary line closely related to the first part, which is the main theme of the present paper. This second part needs further and detailed working out, but provisionally I have arranged it in the following order:

I. Genus Megalorrhipida Amsel.

I. defectalis Walker-typus generis.

II. Generic group Trichoptilus Walsingham.

I. pygmaeus Walsingham-typus generis.

2. californicus Walsingham.

3. lobidactylus Fitch.

4. parvulus Barnes and Lindsey.

ENTOM. I, 5 .
III. Genus Buckleria Tutt.

I. paludum Zeller-typus generis.

2. paludicola Fletcher.

IV. Genus Stangeia Tutt.

I. siceliota Zeller-typus generis.

2. xerodes Meyrick. 
V. Mixed generic group.

This group contains species whose exact generic position has not yet been determined. Amongst tropical species described as Oxyptilus or Trichoptilus there are some belonging to the genera enumerated above (except exclusively holarctic, like Capperia, Geina, Oxyptilus, and Crombrugghia), but some belong to new genera not yet described. Probably here should be placed Meyrick's causodes and some other Indo-Malayan and neotropical forms differing very much in their external appearance from the abovementioned genera.

I have adopted the generic names Sphenarches Meyrick and Megalorrhipida Amsel (here revived by me) as according to the Rules of Zoological Nomenclature they are available and valid, but both the genera to which I have assigned these names need redefining, as their creators had not the slightest idea of their proper scope, or of the synonymy or geographical distribution of the species belonging to them.

In connexion with the systematic review given above, attention may be drawn to the number of species in each genus. The first group, being better known, particularly in respect of the old world fauna, gives us, perhaps, figures more nearly approximated to those actually occurring in nature. It appears that older genera are more simple in morphological structure and the differences between their species are less pronounced. According to those criteria we may regard the genera Megalorrhipida and Sphenarches as the oldest, and Capperia and Oxyptilus as the youngest in the group under discussion.

\section{MORPHOLOGY}

The very delicate structure of the Alucitidae makes them difficult to preserve in good, undamaged condition, and the material in the several collections which I used for my work was in great part more or less worn, and sometimes even too bad for determination by external appearance only. The species with which we are here concerned are so similar to one another that external appearance is often insufficient for accurate determination. Some of them, as, for example, Capperia celeusi Frey or Oxyptilus parvidactylus Haworth, appear in various forms, sometimes resembling other species. These forms are not sufficiently differentiated to be considered as separate species. Lack of material prevented me from deciding if they were geographical or ecological forms and I found myself quite unable to work out a key for the determination of the species by external appearance. Such work would he possible if we could collect long series of unblemished bred specimens from various localities for the purpose of studying the mutability of species and their sexual and seasonal dimorphism. In view of the difficulties with which I was confronted I was compelled to take into account in my descriptions the external appearance of species to a limited extent only. My classification is therefore based mainly on the morphology of the copulatory apparatus, supported in addition by ecological data. External appearance in the present group is very misleading, and I found myself obliged to describe several new forms, in spite of the existence of many old synonyms. For documentary reasons I have cited old published determinations based on external appearance only. The great number of the mistakes in determination is characteristic of this difficult group. 
During my examination of the copulatory apparatus I have especially taken note of the degree of sclerotization as well as the degree of specialization of its structure as a whole or in its parts. The following types of structure in the male copulatory apparatus are distinguishable:

Ninth segment.

I. Slightly differentiated into parts. Tergum clearly joined with sternum by the pleurae (Megalorrhipida).

2. Distinctly differentiated into separate parts. Tergum not specialized, sternum slightly specialized (Sphenarches, Procapperia).

3. Distinctly differentiated. Tergum not specialized, sternum strongly specialized (Capperia, Geina).

4. Distinctly differentiated. Tergum strongly specialized, sternum very weakly developed (Oxyptilus, Crombrugghia).

Valva.

I. Not specialized, flap-like, unarmed (Sphenarches, Megalorrhipida).

2. Little specialized, differentiated into basal and distal parts, unarmed (Procapperia, Geina).

3. Very specialized, weakly sclerotized, armed (Oxyptilus, Crombrugghia).

4. Very specialized, strongly sclerotized, elaborately armed (Capperia).

Aedeagus.

I. Not specialized, tube-like, faintly sclerotized, slightly curved, not armed (Megalorrhipida, Sphenarches).

2. Little specialized, basal part more developed, tube-like, slightly curved, not armed (Geina, Oxyptilus).

3. More specialized, strongly curved, strongly sclerotized, not armed (Procapperia).

4. Very specialized, very strongly curved, very strongly sclerotized, armed (sometimes asymmetrically) (Capperia).

Analysing the results we can arrange the above-mentioned genera according to the specialization of their genitalia in the following order: Megalorrhipida, Sphenarches, Procapperia, Geina, Crombrugghia, Oxyptilus, Capperia (putting Sphenarches in the second place because it has a more strongly developed uncus than Megalorrhipida). Similarly, as in the preceding paragraph I place Megalorrhipida and Sphenarches at the beginning of the scale, and at the end Oxyptilus and Capperia.

A study of the wing colour and pattern gives us the following grouping:

I. Weak pigmentation, wings coloured yellow or light brown (Sphenarches, Megalorrhipida).

2. Pigmentation a little stronger, wings coloured dark yellow with transitions to rusty, brownish, or greyish tints (Procapperia, Crombrugghia).

3. Pigmentation very strong, wings coloured light brown, rusty to dark brown, with reddish, greyish, or blackish tints (Oxyptilus, Capperia).

Ranging the genera in accordance with their degree of pigmentation one arrives at the same order as before.

The American entomologist Braun (I9I4) studied the phylogeny of the genus Lithocolletis (Lepidoptera) and drew a phylogenetic tree of this genus composed of five branches representing differently coloured species. According to the plates given by her the oldest, ancestral form was coloured light yellow, but the oldest recent 
forms are dark yellow. Young recent forms vary from yellow to dark brown and grey, younger forms are dark yellow or light brown, and the youngest are brown only.

The result of my own studies on the Alucitidae are similar, i.e. the older evolutionary lines exhibit faint pigmentation, and during their evolution they become more and more pigmented and the wing-colour gradually changes from yellow, through rusty, reddish, greyish, to dark brown.

I have not made an exhaustive study of the wing-venation in the Oxyptilus group, but I have compared the drawings given by Amsel (I935) of Megalorrhipida and by Barnes and Lindsey (I92I) of Trichoptilus. According to these authors Trichoptilus has a more complex venation than Megalorrhipida, which has fewer nervures. I do not feel that the drawings are quite accurate. The structure exhibited by Megalorrhipida is very primitive and ancestral compared with that displayed in Trichoptilus, a state of affairs to be seen similarly in the genus Sphenarches, which is ancestral to Capperia. The evolutionary tendency towards reduction of wing-surface in the Plume-moths is familiar, and it is clear that there is at the same time a reduction in the number of veins. As the derived form cannot have more veins than the ancestral, I conclude that the drawings I have mentioned above leave room for some doubt as to their correctness.

The reduction of wing-surface is also to be observed in the group Oxyptilus (sensu lato) if one compares the hind angle of the primaries of the different genera. The evolutionary older forms like Sphenarches or Geina have this hind angle very distinct, but in the younger genera it is gradually disappearing, e.g. very slight in Oxyptilus, scarcely visible in Capperia.

The analysis of pattern and maculation of the wings would also probably show the trend of evolutionary lines in the group Oxyptilus (sensu lato). Unfortunately I had not before me sufficiently fresh specimens to make adequate studies of these features.

The degree of specialization of several external morphological features ranges the genera of the group in an order similar to that arrived at by a study of the male genitalia; the majority of the primitive features characterize the genera Sphenarches and Megalorrhipida. In consequence these two genera are very closely related. Most probably they are both derived from a not too distant common ancestor. However, in spite of their close relationship, these two genera belong to two distinct evolutionary lines. One of them leads to Procapperia, Geina, Capperia, Oxyptilus, and Crombrugghia, the other one (i.e. Megalorrhipida) to Trichoptilus, Buckleria, and Stangeia. It is interesting to see in both lines parallel directions of evolution, and a certain amount of similarity exists not only in the simplest but in the more specialized forms. For example, representatives of both the lines mentioned, Buckleria and Oxyptilus, have similar segmentation of the valva (vide plates of Hofmann, I896). Also the genera Capperia and Stangeia have the aedeagus transformed into a very strongly sclerotized organ, armed with asymmetrical processes. In connexion with these remarks on evolution one must take into consideration that they concern the relationship of the structures of recent living forms belonging to different genera, and the occurrence of similarity between two genera cannot be taken as proof of the derivation of these genera from one another. Nevertheless I think it happens sometimes. 
I realize that it would be easy to call in question my evaluation of the grade of evolution based on a simple macroscopic review of morphological features. Doubtless it would be very useful to have genetically known material for investigation of the histology and the last stadium of development in the pupa. With such material it should be easy (in accordance with biogenetic laws) to find evidence in support of my ideas of the phylogenesis of the group under discussion. Without ontogenetic investigations it is really difficult sometimes to decide whether a particular feature is retrogressive or progressive, and which form is more specialized or more primitive. However, as I have no opportunities for such investigations, I shall do my best in the following sections to adduce further evidence in support of my ideas about evolutionary trends in the group Oxyptilus.

\section{ECOLOGY}

We have few ecological particulars relating to this interesting group. On the basis of my own observations on the ecology of certain palaearctic species I am able to interpret certain other published ecological data relating to the Oxyptilus group. I have found, further, some interesting observations published under wrongly used names, and many that need to be verified by field observations. Some biological particulars have been published by American entomologists. Barnes and Lindsey (I92I) revised the North American Alucitidae (under the name Pterophoridae), basing their work on the morphology of the imagines. They failed to take care to relate the synonymy to the available ecological data, scanty as the valid information on nearctic plumes unfortunately is. Tropical species are the least known from the ecological point of view, for we know so few life-histories.

In the group under review there exist very dissimilar grades of specialization of species and genera in the selection of food-plants. Our knowledge in this matter is as follows:

The genus Capperia is the most specialized. All the known food-plants of the species belong solely to the Labiatae, which is one of the most highly developed groups of plants (Hutchinson, I926). Separate species of the genus Capperia often feed on different but closely related species of plants, as, for example, C. britanniodactyla on Teucrium scorodonia, C. celeusi on T. chamaedrys, and C. polonica on a so far undetermined species of Teucrium of the chamaedrys group. Monophagy is a prominent feature of this genus. I carried out some experiments with larvae of C. fusca feeding on Stachys alpina. I gave them the very similar plant Stachys sylvatica, but they all died of starvation, refusing to touch it. Similarly, larvae of C. trichodactyla transferred from their food-plant Leonurus cardiaca to Ballota nigra refused to touch it.

The genera Oxyptilus and Crombrugghia are limited to the Compositae, but at least some of the species belonging to these genera are oligophagous. Crombrugghia distans has been recorded from Crepis tectorum, C. virens, and Picris hieracioides, all Compositae closely related to each other. Oxyptilus parvidactylus has been recorded as feeding on Hieracium pilosellae and H. laevigatum (Tutt, I907). Other plants such as Marrubium, Stachys, and Thymus have been erroneously recorded for O. parvidactylus. 
The Compositae are an intensively developed group high on the phylogenetic tree. of plants (Hutchinson, I926), and contain many poorly differentiated and often intercrossing forms, as, for example, species of Hieracium. There is some correlation in the wide variability of Compositae-feeding Plume-moths of the genera mentioned above. For example, the species parvidactylus and distans are both very variable in size and colour.

The genus Geina is less specialized in the selection of food. Species of this genus feed on plants belonging to Rosaceae and Ampelideae like Geum, Potentilla, Rubus, and Vitis. According to Hutchinson (I926) both these families are less developed than the Labiatae. The Geina species are not monophagous and they can thrive on some nearly related species of plants belonging to Rosaceae or Ampelideae. I discovered larvae of Geina didactyla on Geum rivale, Geum urbanum, and Potentilla rupestris. When I changed the larvae from any one of the three mentioned plants to another, they survived the change very well. Hofmann (I896) and Schütze (I93I) cited also Leonurus cardiaca and Veronica officinalis as food-plants of didactyla, but these are manifestly incorrect data. I tried these plants as food for larvae of didactyla, but they would not touch them and they died of starvation.

We know only three species of food-plants for the genus Procapperia. These are Scutellaria demnatensis for the African Procapperia linariae (Powell, I922), Scutellaria discolor for the Indian P. pelecyntes (Fletcher, I92I), and Scutellaria alpina for the European P. maculata (Chrétien, I922). As far as we at present know the larvae of Procapperia species live only on Labiatae, but data relating to this genus are few and incomplete.

The genus Sphenarches is perhaps the least specialized as regards the selection of food-plants, the larvae being markedly polyphagous. The following food-plants have been recorded for Sphenarches anisodactylus (but under the name Sphenarches caffersee Systematic Revision): Lagenaria vulgaris (calabash), Luffa sp. (Cucurbitaceae), Dolichos lablab, Cajanus indicus, Mimosa pudica (Leguminosae), Averrhoa bilimbi, Biophytum sensitivum (Geraniaceae), Hibiscus mutabilis (Malvaceae). (see Fletcher, I920, I92I). Hori (I93I) cited also Phaseolus vulgaris (Leguminosae). Thus S. anisodactylus is a polyphagous insect feeding on at least nine species of plants belonging to four different families, none of which is a top group in the evolutionary tree given by Hutchinson (1926); in fact Cucurbitaceae and Leguminosae belong among the more primitive flowering plants. As for food-plants belonging to other genera, the data are not sufficient to make comparisons possible.

Analysing the above-mentioned families, we are able to distinguish among them the three following groups:

I. Primitively organized flowering plants (Cucurbitaceae).

2. More highly organized plants, groups comparatively young with many not very distinct species (Rosaceae, Compositae).

3. Very highly organized older forms having specific features very distinct (Labiatae).

Having regard to their food-plants, we can divide the species discussed above as follows:

I. Polyphagous, feeding on many different species of plants not necessarily even related to each other. 
2. Oligophagous, feeding on a few species of nearly related plants.

3. Monophagous, feeding exclusively on one single species of plant.

Analogically we can divide the genera of the insects. For example, the genus Capperia, living only on one family Labiatae, we can call a 'monophagous genus'.

Summarizing the data discussed above we characterize the genera included in Oxyptilus (sensu lato) as belonging to four groups:

I. The most primitive, containing the polyphagous species (Sphenarches).

2. A little more specialized, containing the oligophagous species, living on a few families of plants (Geina).

3. Yet more specialized, containing the oligophagous species living on one tamily of plants only (Oxyptilus, Crombrugghia).

4. The most specialized, containing the monophagous species (Capperia and probably Procapperia).

From this division the following points emerge. The genus Sphenarches, which we regard as the least specialized morphologically, possesses also the most primitive habit of polyphagy. With increasing morphological specialization this primitive habit became more and more restricted, until ultimately the most morphologically specialized 'monophagous' genus Capperia contains the monophagous species only, all living on closely related species of plants of one family.

As a result of this study another significant fact emerges. The forms of the group under discussion, while passing from polyphagy to monophagy (and becoming more and more phylogenetically old), at the same time change primitive food-plants for more and more specialized (phylogenetically older) forms of food-plants.

The number of generations produced during the season provides also a very important indication of the extent of the phylogenetic evolution of the group. There is little useful information on this subject. From my own observations and judging from the verifiable data extracted from the literature, I am able to state that the species belonging to Capperia produce two generations a year (fusca, celeusi, trichodactyla, britanniodactyla, lorana). In the genus Crombrugghia two generations are produced (distans, tristis), and I think it is also probable that two generations are produced in the genus Procapperia (judging from the appearance of fresh specimens of maculata and linariae taken in August). The species of Oxyptilus appear in one generation (pilosellae, parvidactylus, ericetorum, chrysodactylus). Likewise in the genus Geina, the only European species, didactyla, appears in a single generation. All these data relate to forms living in a temperate climate. The length of the period of development of a single generation and the number of generations during a season appear to be correlated with the degree of specialization of the forms in question. In the case of an increased number of generations greater efficiency and a speeding up of the ontogenetic process is indicated. In other words, the more specialized forms multiply more efficiently and at a greater rate. From the data I have given relating to the above-mentioned genera I conclude that Capperia and Procapperia are further advanced in their evolution than Geina, and Crombrugghia should be regarded as a more specialized evolutionary line than Oxyptilus.

It is commonly recognized that the number of generations depends upon the climatic conditions. Of this there is no doubt, but that does not explain the whole question. 
In warmer countries as the season of vegetation becomes longer, the number of generations increases; but the number of generations is not the most important thing. More important is the length of time taken in the development of one generation-the speed of its development.

The two generations of Capperia and Crombrugghia, in Europe, are not to be explained by their geographical distribution extending farther to the south than that of Oxyptilus and Geina, which have one generation only. On the contrary, in some cases these double-brooded genera live in a much colder climate than single-brooded genera, but they do not lose their bivoltine characteristics. For example, Capperia fusca, even when living in very high and cold places in the Alps or in the Tatra mountains, produces the same two generations that it does in much lower warmer spots. Capperia trichodactyla in north Poland has two generations as in south Poland. Geina didactyla is unable to produce a second generation because it occurs on Geum rivale grown in shady humid alder woods, but even when it occurs in very sunny warm places on Potentilla rupestris and emerges a few weeks sooner, it still fails to produce more than one generation. Oxyptilus chrysodactylus, like other species of this genus, produces one generation in July-August even in south Europe (the numerous data in the literature concerning this species under the name hieracii are sometimes erroneous). It seems that the number of generations depends rather more on specialization of a species and on its phylogenetic development than on climatic conditions.

\section{GEOGRAPHICAL DISTRIBUTION}

The first group of genera is much better known systematically and one can thus fairly accurately define its geographical distribution. It is very characteristic for each genus. In the genus Sphenarches there are known four species only: South African, S. caffer (Natal, Caffraria); North American, S. ontario (Canada); Burmese, S. zanclistes (mountains in Central Burma, $2 \mathrm{I}^{\circ} \mathrm{N}$. lat.) ; and S. anisodactylus with an extremely interesting distribution. This species lives only in tropical countries, from which it has been recorded under various names. It has a very wide distribution. Following careful studies of the genitalia I have been able to verify the occurrence of anisodactylus in the following countries: Peru, West Indies, West Africa, Madagascar, India, Ceylon, eastern Australia, New Hebrides. In addition, I have very little doubt that many of the records made under the name Sphenarches caffer refer to S. anisodactylus, particularly those from the following countries: Brazil, French Guiana, Central Africa, East Africa, Mauritius, Maldive Is., Burma, Sumatra, Java, Philippines, Japan, China, New Guinea, Tenimber, Tonga, Samoa. The same widely distributed species known formerly under the name caffer was also recorded from extratropical countries like Palestine and South Africa, but these records do not refer to anisodactylus but to other species (true caffer and Capperia maratonica). A revision is required of the records from China $\left(30^{\circ} \mathrm{N}\right.$.) and Japan (Hering, $32^{\circ} \mathrm{N}$. ; Hori, $3 \mathrm{I}^{\circ}-$ $46^{\circ}$ N.) given by Hering (I903), Hori (I93I), and Caradja and Meyrick (I935). The drawings of male genitalia given by Hori (I93I) under the name caffer confirm the occurrence of anisodactylus in Japan; at the same time, however, his records from north Japan $\left(46^{\circ} \mathrm{N}\right.$.) are very doubtful. According to Meyrick (I927) this species 
(termed by him caffer) is probably distributed throughout all the tropical countries of the world. Its presence on very isolated Pacific islands is explained by Meyrick as the result of human activity, i.e. as a species introduced with cultivated plants. Even if this happened on some Pacific islands, it is not a sufficient explanation for the presence of this species in many other tropical countries very isolated from each other. Probably further physiographical investigations will disclose the presence of anisodactylus on quite isolated spots having no imported cultivated plants at all. It is very interesting that this very common polyphagous species is at present unknown in Hawaii and in New Zealand where the fauna has been carefully studied. Both are fairly large countries which have been intensively cultivated for a long time, and into which numerous species of animals and plants have been especially introduced for acclimatization; however, anisodactylus does not occur in either.

There are known five species in the holarctic genus Geina. Three of them are North American, one European reaching western Asiatic countries, and one known only from Asia (Tian-Shan Mts.). This genus is widely distributed northwards in both hemispheres, alike in Europe and in the United States and Canada. Geina didactyla is a commonly distributed species in middle and north European countries. Westwards it reaches France and eastwards the Balkan states (Bulgaria) and Asia Minor. It is very peculiar that didactyla does not occur in the British Isles although its food-plants commonly grow there. G. didactyla should be much more widely distributed eastwards in north-west Asia, but we have as yet no data from there.

The genus Procapperia is represented by Mediterranean and Indo-Malayan species. Four Mediterranean species are known from Morocco (linariae), southern France (maculata), Croatia (croatica), and Asia Minor (anatolica). One species lives in Ceylon (pelecyntes). Most probably some other Indo-Malayan species of Oxyptilus (sensu lato) belong also to Procapperia.

The genus Capperia is holarctic like Geina, but is distributed more to the south than Geina. Out of seventeen known species only two are American, viz. ningoris from the middle and south of the United States and evansi from south Canada. The remaining fifteen species are distributed in western and middle Europe and in the European and Asiatic parts of the Mediterranean area. In this area the species of Capperia live very locally and only a few are more widely distributed. No species are known from North Africa. The northern limit of distribution of the genus Capperia in the eastern hemisphere approximately coincides with the southern limits of the Pleistocene glaciation. This line is crossed here and there by Capperia trichodactyla wandering along the rivers Vistula and Oder from southern Poland northwards. In North America C. ningoris shows a similar distribution in the south and middle United States southwards from the limit of glaciation. Along the warm shores of the Pacific only does this species extend farther northwards and reach British Columbia (Blackmore, I922). Quite an exception in the genus is the second American species, evansi, which has wandered as far as southern Canada. Capperia britanniodactyla is distributed in England, Belgium, and in the Rhine valley. The northern and middle parts of the British Isles were glaciated, leaving south and parts of central England only free of glaciation (Zeuner, I945). The distribution of Capperia britanniodactyla in England ENTOM. I, 5 . 
accords almost exactly with these limits. The European and Asiatic species of the genus Capperia are distributed as follows:

I. West European group, containing two species: britanniodactyla (England, Belgium, Rhineland) and lorana (Rhineland).

2. Central European group, containing three species: celeusi (Hungary, Croatia, Serbia, south Poland, Alps, Bavaria, Thuringia, French Pyrenees); trichodactyla (Poland, Germany, Austria, Switzerland) ; fusca (south Poland, Switzerland, north-east France, Croatia, Greece).

3. Euro-Asiatic group, containing three species: hellenica (south France, Italy, Yugoslavia, Greece, Asia Minor) ; tamsi (Spain, Asia Minor, Syria) ; maratonica (Yugoslavia, Greece, Palestine).

4. Mediterranean, insular group, containing three species: polonica (Sardinia, Prince Is.); zelleri (Sicily); marginella (Sicily).

5. Asiatic group, containing three species: washbourni (Asia Minor, Syria, Palestine); fletcheri (Palestine); geodactyla (Armenia).

Thus two species only live in the northern part of west Europe, in middle Europe three, in south Europe six, and in east Mediterranean countries seven. The number of species of Capperia increases towards the south-east; southwards the distribution area of this genus ends on to the Mediterranean islands, but no species is found or recorded from African shores. There are no records from countries lying farther eastwards in Asia like Persia or Turkestan.

The genus Oxyptilus is holarctic like the preceding. It contains seven species. The only North American species (delawaricus) is very widely distributed in the United States and Canada. The other six species live mostly in colder climates in central and north Europe, but some are more widely distributed and reach the Mediterranean countries (chrysodactylus, hoffmannseggi). One living only in northern colder countries is the Scandinavian bohemanni. Of those widely distributed in Europe two are absent from the British Isles, chrysodactylus and ericetorum. The absence of these two species is very interesting. It is not a matter of climate or food-plants; the riddle must be solved in another way. The genus is distributed farther eastwards than the last. According to Meyrick's data (I9I3), not verified by me, some species reach Transcaspia (pilosellae), Caucasus (ericetorum), west Siberia, and Persia (parvidactylus).

The genus Crombrugghia is exclusively palaearctic, but its distribution is more southerly than that of Oxyptilus. In this genus there is no species confined to the northern countries. The most northern species is the middle European tristis. But there is one purely alpine species (kollari). Two species are Mediterranean only, lantoscanus (south France) and laetus (south Europe, Asia Minor, north Africa, Canary Is.). The third south European species, distans, is distributed more widely northward. It reaches the southern parts of central Europe and the British Isles. This is the only British species in this genus.

Insufficient systematic work has been done on the second group of genera to produce more than an outline.

The genus Megalorrhipida represents a group analogous to Sphenarches because it is very widely distributed in the tropics, but, corresponding with its somewhat more 
primitive morphological structure, its geographical distribution is also wider than the distribution of Sphenarches. The genus Megalorrhipida reaches eastwards to Hawaii. It is also more widely distributed northwards in Asia (China, Palestine). In North America Megalorrhipida reaches to the south of the United States. In New Zealand it is absent, like Sphenarches. The generic type is defectalis, which has several synonyms (Fletcher, I93I), having been described under various names from many countries. All these synonyms should be verified by comparison of the genitalia; however, one can say that defectalis is very widely distributed all over the world. Drawings of the male genitalia of this species were published by Amsel (I935) and Barnes and Lindsey (I92I). Although the drawings show different aspects it seems they are of the same species, living alike in the United States and in Palestine. On the basis of ascertained synonymy one can provisionally call this species defectalis Walker, supposing it to be the same species as that described by Walker from the African tropics.

Two representatives of the genus Stangeia are known, the Mediterranean siceliota and xerodes, living in India and Ceylon. S. xerodes is also recorded from New Guinea, Australia, Africa, and Palestine. I cannot distinguish from siceliota the Palestine specimen named xerodes by Meyrick. The Australian specimens of xerodes I saw in the British Museum seem to be a species different from the Indian xerodes. This genus should be carefully revised.

The genus Buckleria differs strongly in the structure of the genitalia from Stangeia, but its distribution is very similar. Two species are known, a central European one occurring also in Great Britain (paludum), and paludicola distributed in India and Ceylon. In the British Museum paludicola has been considered as a synonym of paludum.

The generic group Trichoptilus contains exclusively North American species. They belong probably to several distinct genera, not yet separated. It seems that these North American species represent evolutionary lines quite distinct from those of the European species. They differ morphologically too, and cannot be put together in the same genus Trichoptilus with the Old World's lines Stangeia and Buckleria.

This review of geographical distribution shows that the genera can be placed in the same succession as was obtained from a comparison of their morphology or ecology. The order depends upon such characters of distribution as space and climate as follows:

I. Genera and species most widely distributed all over the world are also the most primitive in their structure and ecological features (Sphenarches, Megalorrhipida).

2. Less widely distributed forms are more specialized (Geina, Procapperia, Oxyptilus).

3. Units most limited in distribution are most specialized (Crombrugghia, Capperia).

There are also some connexions with climate:

I. Most constant characters, not changing over very wide areas, exist in tropical genera. They contain very few species and seem to be arrested in their evolution (Sphenarches, Megalorrhipida).

2. More often differentiating characters are found in genera passing northwards to a colder climate. These genera contain more species (Procapperia).

3. The greatest variability of characters changing over small areas and therefore genera richest 
in species are seen in the most far northward countries (Capperia, Oxyptilus). In these genera there are the biggest tendencies for the formation of new species (vide the variability of celeusi and parvidactylus), and it indicates the bigger expansion of life in cooler climates independently of the phylogenetical lifetime of the forms in question.

The above-mentioned connexions can be seen by comparing genera standing very close to each other such as Capperia and Procapperia or Oxyptilus and Crombrugghia. Besides, it is known that some genera are more common and numerous in species in the north (Geina, Oxyptilus), and on the contrary other genera are more common in the south (Capperia, Crombrugghia). In connexion with this fact one can observe the northern limit of distribution for southern genera (i.e. southern limit of Pleistocene glaciations), but there does not exist any southern limit for northern genera. These northern genera are only more and more rare southwards, but they are distributed as far to the south as the southern genera, and both groups of genera reach the same geographical barriers in the south.

A general glance at the geographical distribution of the group discussed shows where the evolutionary lines are most frequent. Thus, in the northern hemisphere there exist more genera and species than in the southern hemisphere. Similarly more forms are known from the eastern hemisphere than from the western. Thus it appears that in the northern and eastern neighbourhood of the Mediterranean basin several evolutionary lines are the most frequent. Unfortunately there is not sufficient material from western Asiatic countries to determine the position of the centre of this concentration of evolutionary lines. However, one assumes this centre to be in the area of the countries of the Middle East.

\section{PHYLOGENY}

In the preceding sections data concerning the morphology, ecology, and geographical distribution of the group Oxyptilus (sensu lato) have been discussed. The relation of this information to questions concerning the age and origin of our group may now be considered.

In connexion with problems of the geographical distribution of various groups of animals numerous theories have been advanced as more or less hypothetical solutions. But even the theories of hologenetic evolution, and of old bridges between ancient continents, do not fully explain all the questions of animal geography.

The most synthetic and also the most revolutionary attempt to reproduce the history of our globe resulted in the theory of continental drift (Taylor, I9Io; Wegener, I9I2, I924, I937). For a long time this theory was severely criticized. However, its wide usefulness in many branches of natural sciences attracted the attention of several scientists. Of recent years there have appeared several important works, in particular those of Du Toit, Jeannel, Zeuner, and others, which have strengthened the theory of continental drift in the scientific world.

Below is set out an attempt to explain the geographical distribution of the group Oxyptilus (sensu lato) on the basis of Wegener's theory. It may be a useful contribution both to entomological studies and to a further investigation of the TaylorWegener theory. 
According to palaeontological data the first appearance and the beginning of the evolution of the Lepidoptera occur in the middle of the Jurassic. About that time appear the first flowering plants. The Lepidoptera of that time belonged to the most primitive and now extinct group Palaeontinidae. The intensive development of Lepidoptera started with the beginning of the Cretaceous simultaneously with the progress of flowering plants (Angiospermae). By that time the differentiation of Lepidoptera had so far advanced that the first representatives of some families existing at present can be found. The very strong development of Angiospermae in the second half of the Cretaceous justifies the assumption that at that time the immediate ancestors of recent generic groups in Lepidoptera appeared. Among Alucitidae one can suppose the existence of the ancestral form from which all these groups having a patch of scales on their secondaries originated (Platyptilia, Oxyptilus-Trichoptilus group). Unfortunately the very delicate structure of the Plume-moths did not allow their preservation as fossils. Therefore we are forced in this group to study its palaeontology without fossils. This is very difficult, but we find some very important hints in the geographical distribution of recent forms. The genera Megalorrhipida and Sphenarches occur over the whole area of the tropics of our globe. Their common ancestor (probably common for Platyptilia too) probably initiated the development of the genera mentioned, still in the Cretaceous, somewhere on the Lemuria-Angara continent. In this way could be explained the distribution of these genera in the tropics of both hemispheres, that is, over the Euro-Asiatic (Angara) and Indo-African continents in the east and in the tropical parts of American continents (Archigalenis and Archiguiana) in the west, before these continents became separated by seas. As we see on the maps of Köppen and Wegener (reproduced also by Jeannel, I942) the recent areas of northern Brazil and of Malaya were continents since the Mesozoic and since that time have not changed their tropical climate. But, on the other hand, their junction by land in the tropical area, that is, the junction of the tropical continents of the western hemisphere with the Angara continent, existed only on the break of the Mesozoic and Tertiary, in the period of Montien when the Indo-African continent was separated already from Angara. Then, in the Montien, the tropical genera Sphenarches and Megalorrhipida passed westwards to the tropical areas of North, South, and central America which were united with the West Indian islands at this time. The climatic conditions of those times did not allow these tropical genera to extend their distribution towards the Australian-New Zealand continent by the southern route through the continents of South America (Archiplata), Palaeoantarctis, and Australia. Only the ancestor of the genus Platyptilia, not attached particularly to a tropical climate, passed by this way from Archiplata to Australia and New Zealand along the sea-shores of Palaeoantarctis which had during the Montien a moderate climate. In subsequent periods this migration route was interrupted by the cooling of the climate (Eocene), by sea transgression separating the Australian continent, and by definite separation of New Zealand from Australia (Oligocene). The contact of the Australian continent with south-east Asiatic areas took place much later (Pliocene) and only then could the genera in question pass to Australia, but not to New Zealand, which was already completely isolated. In this way one can explain the presence of only the genera Sphenarches and Megalorrhipida 
in the tropics of South America, the West Indian islands, Malaya, and Australia from the end of the Cretaceous until the middle of the Tertiary. At that time the greater part of the African continent, with Madagascar and India with Ceylon, had a very cool climate and only the northern part of the Indo-African continent (Egeida Meridionalis) extending very far to the north had a tropical climate. During this period the thermophilous forms could not pass to Ceylon nor to Madagascar because of the proximity of the polar circle and a very severe climate. In warmer, more equatorial African areas, having a moderate climate during the Eocene, the species Sphenarches caffer was differentiated. It could not pass to Madagascar because this island was completely isolated from the African continent. The temporary contact of Madagascar with the continent happened much later, at the end of the Miocene, but in the meantime, since the Eocene, the Equator moved very far southwards and Sphenarches caffer, adapted to a cooler climate, moved also to South Africa and could not use this north Malgash bridge. However, this tropical bridge was very useful for the tropical species Sphenarches anisodactylus to enter this island. It passed also to India and to Ceylon, then united with India. The North American species of Sphenarches arose from a line isolated after the Montien in Archigalenis, the climate of which during the Tertiary became more and more cool. By Pliocene times the climatic conditions there were like those of to-day. At the end of the Tertiary, when central America emerged and the route to South America was open anew, this North American Sphenarches was already too much changed and adapted to a cooler climate to use the connexion.

The distribution of these genera in the Pacific area is a separate problem. The genus Sphenarches reaches in this area New Hebrides, Tonga, and Samoa, but Megalorrhipida is known even from Hawaii. The fauna of the Hawaiian islands is well known and it seems unlikely that a common polyphagous genus like Sphenarches should have been overlooked. Wegener's maps suggest that the Pacific islands, or at least a part of them, were united with the Malayan area in the Montien. Jeannel (I942) states that the Hawaiian islands had never a connexion with the American continent. One can suppose, therefore, that Hawaii was the first to be isolated from the Angara-Lemuria continent (which could not happen before the end of the Cretaceous), before the appearance of Sphenarches on the east shores of that continent. The isolation of Samoa and Tonga, being nearer to the continent, should have taken place later, after the appearance of Sphenarches in this area. These differences in the distribution of Sphenarches and Megalorrhipida seem to show that Megalorrhipida is an older line than Sphenarches and also that the centre of evolution of this group was on the Angara continent (Eurasia).

Sphenarches anisodactylus presents an unusually interesting phenomenon in this genus. From a comparison of the male copulatory apparatus from several localities I ascertained that this species occurs in the tropical countries of both hemispheres. In this case the lines of the New and Old Worlds of this species must have been isolated from each other since the times of Montien, i.e. for about sixty million years (Zeuner, I946) or, one can also say, during more than sixty million generations (dependent upon the number of generations a year). It is difficult to suppose that the species endured such a long time without change. On the other hand, it would be 
even more difficult to accept the hypothesis that in several areas very remote from each other and very well isolated the same species could suffer identical changes by identical evolutionary processes producing the same final results during such a long time. Zeuner (I935) reckoned the time needed for the development of a new species in certain mammals to be about 500,000 years, i.e. about 25,000 generations. But evolutionary processes do not always move at such a rate and sometimes they seem even to stop for a very long time. For instance, recent species of insects are known in Oligocene ambers which are about 40 million years old. This fact makes easier the supposition that Sphenarches anisodactylus endured in the tropics for 60 million years without changes. It seems that the range of time and number of generations necessary for the speciation of a new animal species varies within wide limits. It is possible also that in spite of Zeuner's (I943) opinion the factor of time does not play a decisive part in this matter and evolution of a new species depends more on other factors than on time and the number of generations. It seems that time, even very long, does not act as a factor of importance when climatic changes fail, and on the contrary, a very short time span in the presence of climatic changes causes intensive evolutionary effects, as one sees on comparing recent British and continental insects living in areas which have been separated only a few thousand years. If it is admitted that Sphenarches anisodactylus endured without changes since the period of Montien (and there seems no other possibility), the consequences of this assumption must also be admitted. On this admission Sphenarches anisodactylus is a living ancestral form of the closely related species having narrower distribution like the South African caffer or North American ontario, and, further, anisodactylus is the living ancestor of certain descended genera which will be discussed below.

An analogous case is afforded by Megalorrhipida defectalis, which is probably the ancestral form for the Trichoptilus group, if, of course, further investigations confirm the facts about its distribution as at present known. This is a still older form, as shown by its wider distribution (Hawaii), simpler structure (uncus, valva), and greater elasticity in climatic adaptation, and also its presence outside the tropics. The similarity of the genitalia of the two genera suggests the possibility that Megalorrhipida is ancestral to Sphenarches. However, the structure of the primaries (second lobe) does not agree with such a supposition. Studies on the ontogenetic development of these forms could be of decisive value in this case.

During the Tertiary the above-mentioned ancestral forms gave rise to several new evolutionary lines which since then have become specialized as distinct, recent genera. These genera are more or less close to Sphenarches or Megalorrhipida, but they are more specialized and they are much more limited in their geographical distribution. Let us see first which forms seem to derive from Sphenarches. The line morphologically very close to Sphenarches is represented by the genus Procapperia. Its recent Indo-Mediterranean distribution indicates that Procapperia dates from the times of Montien when the territories of Indo-Africa and Egeida Meridionalis were joined together as one continent, separated by the sea of Tethys from the shores of Eurasia. The Eocene marine transgressions divided this continent into three parts having different climates, and consequently correlated groups of species should have become differentiated, namely, the Mediterranean, Indian, and probably the African group. 
The last has not been discovered so far, but may exist in the African tropics. The Mediterranean group being under the influence of climatic changes in Pleistocene times, began to differentiate as the latest and therefore the species of this group are still very 'young' and morphologically not very well stabilized.

The genus Capperia dates from the European tropics of the Eocene, when the direct contact with the tropics of the New World was already interrupted. Europe at that time was an area subjected to marine transgressions and divided into several islands, of which the largest were Tyrrhenis and Egeida Septentrionalis. This insular character provided particularly convenient conditions for the separation of new forms. Morphologically three groups are recognizable in the genus Capperia, which were differentiated during the first half of the Tertiary. The most primitive group has an unarmed aedeagus (type: hellenica). It occurs in south Europe only. It is the closest group to Procapperia. In addition to it there exist two groups with a more complicated aedeagus structure. The more northern has the aedeagus with symmetrical processi (type: celeusi), the southern has asymmetrical processi on the aedeagus (type: fletcheri). During the Oligocene the more northerly group (symmetrical aedeagus) passed to North America by the northern Atlantic bridge lying in a moderate climate, and gave rise to the two Capperia species now living in North America and belonging to the celeusi group. In the Miocene this North Atlantic route was interrupted by the moving of the North Pole and the considerable coolness of the climate. From the middle of the Tertiary the European climate became more and more cool until the critical times of the Pleistocene. The climatic changes caused an acceleration of evolutionary processes in the direction of greater specialization. A considerable number of species differentiated. During the Pliocene the configuration of continents and islands in the Mediterranean area became similar to the present. The bridges of land between Sardinia and the Iberian peninsula and between Sicily and Tunisia disappeared. The new islands were formed approximately where Sicily and Sardinia are now (Jeannel, I942). At this time there probably appeared the Mediterranean insular species (polonica, marginella, zelleri). But insufficient data exist concerning the distribution of these very little known or recently distinguished species to be able to establish their origin exactly. Further investigations are needed. Capperia polonica is known from Sardinia and from Prinkipo Islands in the Marmora Sea. On the map of Pliocene Alpine foldings (Du Toit, I937) both these localities, i.e. Sardinia and Marmora are to be seen on the same curve running from the Balearic Islands through Corsica to the sea of Marmora and Asia Minor. On the other hand, Sicily, which is inhabited by allied insular species, appears on another curve running through North Africa and the Apennines. A degree of coincidence between the distribution of species and the curves of Alpine foldings may be quite accidental, but it might be of some significance. However, further faunistic investigations in the Mediterranean area must establish whether a relation does exist here or not. Two other insular species, Capperia marginella and C. zelleri, are known from Sicily only. It is possible that they are exclusively Sicilian endemics, but this question needs further investigation. However, these two closely related species constitute a very well-differentiated group distinct from other related groups. Probably these two species were formed in the Pliocene on two islands occupying the present position of 
Sicily. On the other hand, in the geocratic Post-pliocene period there existed a junction between Europe and Africa through Sicily and Sardinia. Jeannel (I942) even supposes the possibility of the existence of a Euro-African bridge down to interglacial periods. At such a period there would have existed probably an opportunity for the species mentioned to spread into the Apennine peninsula and northern Africa. Unfortunately no material belonging to the genus Capperia is known from those countries. The glacial catastrophe in the Pleistocene destroyed the existing species of Capperia in most parts of Europe, and probably in northern parts of west and central Asia too. The present northern limit of distribution of this genus provides evidence of this, in so far as it is shown by the remaining small areas of distribution of some Tertiary relict species near the northern limit of the distribution of the genus (lorana, britanniodactyla).

Capperia britanniodactyla is not, as was formerly thought, an endemic British form. It occurs also in the Rhineland. I could not find any morphological differences between British and continental specimens. Evidently the period of isolation of the British Isles from the Continent has been too short for the appearance of differences in British form. The junction of the British Isles with the Continent existed down to recent times, but britanniodactyla originates from the Tertiary. Zeuner (I946) puts the approximate date of separation of the British Isles from the Continent at 7,0006,000 B.C., i.e. in post-glacial times. Capperia britanniodactyla is a very strongly specialized and separated species which appeared in the Tertiary when communication between Europe and North America had been already interrupted, i.e. about 30 million years ago. In comparison with that the 8,000 years during which the British specimens have been isolated is very short and evidently insufficient to permit the development of visible morphological differences in such a specialized species. In such a case it would be more probable to find, if they exist, ecological differences and maybe some changes in the life-history, but there is at present no information on these points. The northern limit of the distribution of britanniodactyla is very characteristic. It follows nearly exactly the southern limit of the Pleistocene glaciations which covered Scotland, northern, and partially central England. Southern England was never glaciated (Zeuner, I945). Of twenty-two localities in Britain from which britanniodactyla is certainly recorded only six are situated outside the old limit of the glaciation, and even they are mostly near to this limit. These are indications of post-glacial migration. The remaining localities are within the never glaciated area. Owing to the maritime climate, the nearness of the glacier did not greatly decimate the flora and fauna of southern England (Jeannel, I942), and the climate of the country during the glaciations was scarcely a few degrees cooler than at present (Beirne, I943). It is thus very probable that britanniodactyla was able to endure the glacial period in England without the support of populations from the interior of the Continent. Besides, the very high specialization of the species is not propitious for easy migration. Very specialized forms, like britanniodactyla, are very conservative in changing locality. It is also possible that in such cases tropisms exist like those that play such a great part, for example, in the distribution of birds. When britanniodactyla appeared during the Tertiary it was faced very soon with a climate becoming more and more cool, and under these conditions a negative boreotropism ENTOM. I, 5 . 
could arise as a specific feature of britanniodactyla. This character, if it does exist, should be much more efficient against the northwards expansion of the species than any geographical barrier. However one tries to explain the distribution of britanniodactyla, it is a fact that it shows a northern limit closely following the southern limits of glaciation. It is very interesting that large organisms capable of long flights, like some birds or bats, to which geographical barriers like the English Channel present no difficulty, have the same northern limit of distribution as britanniodactyla. In Bartholomew's Atlas (I9II), for example, there are mentioned the following families of birds as distributed in the southern part of the British Isles only: Timellidae, Plataleidae, Gruidae, Sittidae, Upupidae, Oedicnemidae, Picidae, Peristeridae. Other examples given there of animal groups having a similar distribution in Great Britain are: Rhinolophidae (Bats), Myoxidae (Rodents), Dreissensia (Molluscs), Lucanus, Trox (Beetles), Nemeobiidae, Papilionidae, Limenitis, Gonepteryx (Butterflies).

The eastern part of the Mediterranean area represents the richest asylum in which Tertiary forms of the group discussed survived during the Pleistocene. The eastern shores of the Black Sea, southwards of the Caucasus, are generally known for their many botanical Tertiary relics. The area would be especially interesting for species of this group. Unfortunately nothing is known from the region. Other interesting localities could be found where possible Tertiary relicts occur on the probable route of the genus Capperia along the southern frontier of Asiatic Russia, where some forms might have survived during the Pleistocene period. The glaciation of northern Asia reached $6 \mathrm{I}-62^{\circ}$ of $\mathrm{N}$. latitude (Antevs, I928), i.e. about ten geographical degrees less than in Europe and America. It is also very interesting to know how far eastwards the genus Capperia was distributed during the Tertiary. If, as is possible, it then reached Manchuria it has a good chance of surviving until the present. But these questions need further investigation on the spot.

On the continent of Angara, during its isolation from Europe in the first half of the Tertiary, two main lines derived from Sphenarches were separated. These lines initiated the recent genus Geina and, on the other hand, the genera Oxyptilus and Crombrugghia. During the Oligocene these lines passed by the arctic route in a moderate climate to North American territory. Intensive evolution of these lines happened later as the climate became more and more cool. The genus Geina developed more strongly in the American and Oxyptilus in the Eurasian continent. The more thermophilous line of Oxyptilus passed before the Pleistocene to the Mediterranean area and formed there the genus Crombrugghia. The genera Geina and Oxyptilus adapted themselves for a cooler climate. The appearance of these two genera in Europe must have been very late, probably after the glacial period, because Geina did not reach the British Isles at all and Oxyptilus only in two species.

Another group of evolutionary lines having a morphological structure similar to Megalorrhipida, and possibly derived from it, consists of the genera Buckleria, Stangeia, Trichoptilus, and probably some North American genera as yet undescribed. On this group of genera insufficient systematic work has been done to indicate more than an outline of their origin. The genera Stangeia and Buckleria have a type of distribution like that of the genus Procapperia, i.e. they form lines deriving from Egeida Meridionalis. Stangeia is distributed from the Mediterranean countries 
(siceliota) to the Indo-Australian area (xerodes). Buckleria is distributed from Ceylon and India (paludicola) to central Europe and Great Britain (paludum). These two genera, very similar externally to each other, belong to two very different evolutionary lines, which it is impossible to place in the same systematic unit. The genus Trichoptilus represents another line quite different morphologically (pygmaeus) and phylogenetically, which separated on the North American continent after the breaking of the communication with the Euro-Asiatic continent which existed in the Oligocene. Other North American species usually placed in Trichoptilus, like parvulus, californicus, lobidactylus, need further investigation and constitute probably other genera not yet described.

From the above considerations it appears that the genera which, on the basis of their morphology, ecology, and distribution, are to be considered as the less specialized (Sphenarches, Megalorrhipida) are really the most primitive and phylogenetically the least changed in the discussed group. The genera of this group put in order according to their phylogenetic age give a similar succession to that reached in the preceding sections, beginning with the most primitive Megalorrhipida and Sphenarches, passing to Procapperia and Geina, and gradually to Capperia, Crombrugghia and Oxyptilus as the most developed and specialized genera in the group.

\section{SYSTEMATIC REVISION}

\section{Genus Sphenarches (Meyrick), I886}

Typus generis Oxyptilus anisodactylus Walker, I864 (= synophrys Meyrick, nec caffer Zeller). Sphenarches gen.n., I886, Meyrick, Trans. Ent. Soc. Lond. 1886: 8 ('type: synophrys Meyr.'). Sphenarches Meyr., I910, Meyrick, Wytsm. Gen. Ins. 100: 6 ('type: caffer Zeller = synophrys Meyr.').

Sphenarches Meyr., 1931, Fletcher, Cat. Ind. Ins. 20: го.

Sphenarches Meyr., I931, Hori, Bult. Sci. Fak. Terk. Kjuŝu Univ. 4.

Palpi without tuft of scales on second joint. Spot of scales very near top of third lobe of hind wing. This genus is distinguished by the very simple structure of the copulatory organs. Aedeagus straight or slightly curved, weakly sclerotized, not armed. Valva a weakly sclerotized lobe, simple, not armed. Ninth tergum weakly developed. Ninth sternum of the shape of triangular vesicular organ, sometimes modified as a more or less large plate covering the rest of the ventral side of the copulatory apparatus. Uncus well developed. Bursa copulatrix without signum. Ostium bursae slightly more sclerotized but without any marked characteristics.

The following species are included in the genus: anisodactylus Walker, caffer Zeller, ontario McDunnough, and zanclistes Meyrick. ${ }^{\mathrm{I}}$ It is possible that an examination of all the exotic species described by Meyrick as Oxyptilus may result in the transfer of further species to Sphenarches. The species named are probably all polyphagous.

Meyrick was apparently very vague about the genus. He described zanclistes (I905) as an Oxyptilus. This led later authors to make similar mistakes; McDunnough described his ontario (I927) as Pterophorus; Walsingham (I897) considered Geina periscelidactyla Fitch to be a Sphenarches.

I Sphenarches chroesus Strand, 1913, from Spanish Guinea (Alen), most probably is only a synonym of anisodactylus. 
The geographical distribution of Sphenarches is extremely wide. It appears in the tropics of both hemispheres and in the zone of moderate climate on either side of the equator.

\section{Sphenarches anisodactylus (Walker), I864}

(Plate I8, figs. 47, 48, 50, 53)

Oxyptilus direptalis Walker, I864, Cat. Lep. B.M. 30: 934 (partim).

Oxyptilus anisodactylus Walker, 1864, Cat. Lep. B.M. 30: 934-935.

Pterophorus diffusalis Walker, I864, Cat. Lep. B.M. 30: 945.

Sphenarches synophrys, Meyrick, I886, Trans. Ent. Soc. Lond. 1886: I7-18.

Sphenarches caffer Z., Meyrick, I887, Trans. Ent. Soc. Lond. 1887\%: 268 (partim).

Sphenarches caffer Z., Walsingham, I89I, Ind. Mus. Notes, 2: 20-2I (partim).

Sphenarches caffer Z., Walsingham, I897, Proc. Zool. Soc. Lond. 1897: 56-57 (partim).

Sphenarches caffer Z., Hering, 1903, Stettin. Ent. Ztg. 64: 96 (?).

Sphenarches caffer Z., Fletcher, 1909, Spolia Zeylan. 6: 2I-22 (partim).

Sphenarches caffer Z., Meyrick, I9Io, Wyts. Gen. Ins. 100: 6 (partim).

Sphenarches caffer Z., Meyrick, I913, Lep. Cat. 17: 5 (partim).

Sphenarches chroesus Strand, 1913, Arch. Naturgesch. "78: A, 12: 66 (?).

Sphenarches caffer Z., Fletcher, I92 I, Mem. Dep. Agric. India Ent. 6: 9-13 (partim).

Sphenarches caffer Z., Fletcher, I931, Cat. Ind. Ins. 20: Io-I I (partim).

Sphenarches caffer Z., Hori, I93I, Bult. Sci. Fac. Terk. Kjusu Univ. 4, (3).

Pselnophorus dolichos Matsumura, I931, 6000 Ill. Ins. Japan: 1056, fig. 207 I.

Sphenarches caffer Z., Hori, 1934, Mushi, '7: 21 ('= dolichos Mats.').

Material examined. The following specimens in the British Museum were examined:

I. Male specimen, type of Walker's anisodactylus, labels as follows: 'Oxyptilus anisodactylus Wkr., type 0', 'Type', 'Ceylon', 'i8. Oxyptilus anisodactylus' and 'I947/50' (praep. genit.).

2. Male specimen, type of Walker's diffusalis: 'Pterophorus diffusalis Wkr. Type ơ', 'Type', 'Moreton Bay', '55. Pterophorus diffusalis' and 'I947/5I' (praep. genit.).

3. Male specimen, paratype of Meyrick's synophrys: 'New Hebrides, Mathew, 2274', 'Walsingham Collection I9IO-427', 'Sphenarches synophrys Meyr. Paratype 2' and 'I $947 / 54$ ' (praep. genit.).

4. Female specimen from W. Africa: 'Bathurst, Gambia, W. Africa, I887, Carter 1070', 'Walsingham Collection, I910-427', 'Sphenarches caffer Z., named by Wlsm.' and ' $1947 / 53$ ' (praep. genit.).

5. Male specimen from W. Africa, det. in the B.M. collection as caffer Z.: 'Bathurst, Gambia, W. Africa, 1887, Carter 1069', 'Walsingham Collection 1910-427' and 'I947/5' (praep. genit.).

6. Male specimen from Peru: 'Callao Peru, 25.x.-3I.xii.r883, Walker 309I', 'Walsingham Coll. r910-427', 'Sphenarches caffer Z. named by Wlsm.' and 'I947/6r' (praep. genit.).

7. Male specimen from West Indies: 'Balthasar (Windwardside) Grenada, W.I., H. H. Smith', 'Walsingham Collection 1910-427, 65010', 'Sphenarches caffer Z. Named by Wlsm.' and '1947/62' (praep. genit.).

8. Male specimen from Madagascar, det. in the B.M. collection as caffer Z.: 'Madagascar, H. Perrot', 'Paravicini coll., B.M., 1937-383' and '1947/63' (praep. genit.).

9. Male specimen from India, det. in B.M. collection as caffer Z.: 'Nilgiris, Hampson Coll., 89-129' and 'I947/64' (praep. genit.).

Nos. I and 2 are in the British Museum Type collection, the remainder in the general collection, labelled Sphenarches caffer Z. It was not possible to examine Sphenarches chroesus Strand, described from Alen, Spanish Guinea, but it is best to assume, from 
Strand's description, that chroesus is a synonym of anisodactylus until such time as the type, or topotypes from Alen, can be examined.

Copulatory apparatus. Preparations of the types mentioned are preserved, whole, in alcohol. It was necessary, therefore, to examine them in this state, without sectioning or staining. No differences were observed in any of the male genitalia from the material examined. The structure is very simple. The valva is a spoon-like concave lobe, slightly sclerotized, without folds, processes, or spines. Aedeagus thin, tubular, nearly straight, curved ventrally towards the tip. The ninth sternum resembles a triangular vesiculum reaching to the centre of the valva only from its base. The ninth tergum takes the form of a small, triangular membranous flap. Beneath the tergum is the well-developed uncus curving ventrally. The female organs are also very simple. Bursa copulatrix without signum. The eighth sternum without any marked characteristics. The end of the ductus is more strongly sclerotized, terminating in a simple, unarmed ostium. Comparison of the preparations with the drawings of Hori (1.c., pl. x, figs. 6-8) revealed no differences.

General appearance of imago. The species varies considerably in size. Wing spread, I2-I7 mm. The smallest specimens seen were from Grenada (I2 mm.) and Ceylon (I2.5 mm.), the largest were from Nilgiris ( $17 \mathrm{~mm}$.) and from Gambia (I3$\mathrm{I} 6 \mathrm{~mm}$.). It is unlikely that the variation in size has any connexion with geographical distribution as Fletcher (I92I) records wing spreads between I3-I5 mm. for Indian specimens, yet in the British Museum there are specimens up to $\mathrm{I} 7 \mathrm{~mm}$., as recorded above. The colour of fresh specimens is dusty dark yellow. Slightly worn specimens are whitish-yellow. These conditions may give rise to the opinion that the species is variable in colour, but this is not the case.

Early stages. Data on life-history are given by Walsingham (I89I), Fletcher (I909, I92I), and Hori (I93I). Fletcher's contribution (I92I), based on Indian material, is very full, containing ecological details and descriptions of early stages. It is stated that the species is very polyphagous (see section 5) and has several generations a year. The development of a winter generation lasts about two months, spring and autumn generations about half this time.

Geographical distribution. The species is distributed throughout the tropics except in the Hawaiian islands (see section 6). It is present in some Pacific islands. Such widespread distribution has been attributed to the influence of cyclones and powerful air-streams (Fletcher, I9I0). The extensive distribution of anisodactylus (under the name of 'caffer Z.') was considered due to human agency (Fletcher, I92I). Meyrick (I927) suggests that it was introduced in the Samoan islands in imported plants of the families Cucurbitaceae and Leguminosae. This supposition is quite inadmissible when it is realized that these plants are not readily transplantable and are invariably transported to the islands in seed only. The seed will have been harvested and dried before shipment and the larvae of anisodactylus are unable to feed on seeds. The passage of living eggs and pupae is highly improbable in view of the brief life-cycle in these stages. The egg stage lasts two to six days (Fletcher, I92I). During this period it would be impossible for the food-plant to be harvested, the seed gathered and shipped to the islands, and for the newly emerged larvae to find fresh food-plants. Freshly emerged larvae, especially in the tropics, must have immediate access to 
suitable food or perish. On dried seeds they would die during transit. Another point is that anisodactylus lays its eggs on flowers and leaves only, never on seeds (Fletcher, I92I). In the previous section an attempt was made to attribute the wide distribution of anisodactylus to Continental Drift, surely a more probable theory in relation to this question.

\section{Sphenarches caffer (Zeller), I 852}

$$
\text { (P1. I8, fig. 49) }
$$

Oxyptilus caffer sp.n., Zeller, 1852, Linn. Ent. 6: 348-349.

Oxyptilus caffer Zell., Zeller, I852, Micr. Caffr. I18.

Oxyptilus walkeri n.s., Walsingham, 1881, Trans. Ent. Soc. Lond. 1881: 279-28o.

Sphenarches caffer Z., Meyrick, I887, Ibid. 188\%: 268 (partim).

Sphenarches caffer Z., Walsingham, I891, Ind. Mus. Notes, 2: 20-2I (partim).

Sphenarches caffer Z., Fletcher, I909, Spolia Zeylan. 6: 21-22 (partim).

Sphenarches caffer Z., Meyrick, I910, Wyts. Gen. Ins. 100: 6 (partim).

Sphenarches caffer Z., Meyrick, I9I3, Lep. Cat. 17: 5 (partim).

Sphenarches caffer Z., Fletcher, I92 I, Mem. Dept. Agric. India Ent. 6: 9-13 (partim).

Sphenarches caffer Z., Fletcher, I93I, Cat. Ind. Ins. 20: Io-I I (partim).

Material examined:

I. Single male specimen from South Africa (British Museum collection), labelled as follows: 'Kimbolton, Eastcourt, Weenen, Natal, Htchsn. I885, 325'; 'Walsingham collection, I913-427'; 'Sphenarches caffer Z., named by Wlsm.' and 'I947/52' (praep. genit.).

As Zeller's type specimen (a male) of caffer is in the Stockholm Museum (see Walsingham, I89I) there has been no opportunity of examining it. Zeller described this species from a single specimen from Caffraria giving only general information as to locality in the following words: 'Habitat in tractibus fluviorum Limpoponis et Gariepis'. As there were no fewer than three South African rivers named Gariep in the last century it is impossible to give any accurate definition of the original locality for caffer. The only possible definition is SE. Africa between $25^{\circ}$ and $30^{\circ} \mathrm{S}$. latitude. On old maps the name Caffraria was given to the SE. African territory in latitude about $30^{\circ} \mathrm{S}$. and containing the greater part of Natal. The specimens described by Walsingham (I88I) as Oxyptilus walkeri also originated from Natal. The types of this species are in the Capetown Museum, but unfortunately are without abdomens. Meyrick (I887) as well as Walsingham (I897) considered walkeri a synonym of caffer. Being at present unable to examine the Stockholm type specimen it is considered that the above-mentioned specimen from Natal (Kimbolton) is the topotype of Sphenarches caffer Zeller (= walkeri Walsingham).

The copulatory apparatus of the specimen from Kimbolton is of the same general appearance as anisodactylus, but with the valva and ninth sternum less primitive. Valva elongate, much narrower at the base than at the apex, which forms an enlarged flap. The ninth sternum is triangular, but much longer than in anisodactylus, reaching $\frac{2}{3}$ of the length of the valva. The ninth tergum triangular, membranous and weakly developed. Uncus and aedeagus similar to anisodactylus.

Early stages and food-plant unknown.

Geographical distribution: South Africa, Natal. 


\section{Sphenarches ontario (McDunnough), I927}

Pterophorus ontario McD., McDunnough, I926, Rep. Ent. Soc. Ontario, 25: 49 (nomen nudum). Pterophorus ontario sp.n., McDunnough, 1927, Trans. R.S. Can. 192\%: I76, pl. I, fig. I.

It was not possible to examine this species. From the description and the figure of the male copulatory apparatus in McDunnough's publication (I927) there is no doubt that this form comes in Sphenarches.

The male copulatory apparatus most resembles Sphenarches caffer, but the valvae are more rounded at the ends.

Judging from McDunnough's description the imago also is similar to caffer. Wing spread is $\mathrm{I} 4 \mathrm{~mm}$.

Early stages and food-plant unknown.

Geographical distribution: Canada, Ontario.

\section{Sphenarches zanclistes (Meyrick), I905}

$$
\text { (P1. I8, figs. 5I, 52) }
$$

Oxyptilus zanclistes sp.n., Meyrick, 1905, J. Bombay Nat. Hist. Soc. 16: 581-582.

Oxyptilus zanclistes Meyr., Meyrick, 1913, Lep. Cat. 17: 5 (partim ?).

Oxyptilus zanclistes Meyr., Corbett and Gates, 1926, Bull. Dep. Agric. F.M.S. 38: I I (?).

Oxyptilus zanclistes Meyr., Fletcher, I93I, Cat. Ind. Ins. 20 (partim ?).

Specimens examined from Meyrick's collection in the British Museum:

I. The male specimen (the first in the series of nine specimens named in Meyrick's collection as zanclistes) labelled as follows: 'Fort Stegman, Burma, N.M. . . . .88', ' 'Oxyptilus zanclistes Meyr., 9/I, E. Meyrick det. in Meyrick Coll.', 'Meyrick Coll., B.M., I938-290' and ' $1947 / 72$ ' (praep. genit.). This specimen is considered the lectotype. ${ }^{2}$

2. The specimen without abdomen: the same locality as above.

3. The remaining seven specimens are from India (Assam and Coorg, 3 specimens), Ceylon (2 specimens), and N. Australia (2 specimens). One specimen of them (Khasi Hills, Assam, iii. 1907) has copulatory apparatus identical with that of the lectotype (praep. genit. no. 'I947/Ior'). It is not known whether the remaining specimens belong to the same species as the genitalia were not examined.

Male copulatory apparatus differs more from the generic type in this species than in any other. It approaches somewhat to the genus Geina. The most marked characteristic is the ninth sternum, consisting of a large rounded plate, cut out at its top centre. This plate covers the rest of the ventral side of the copulatory organs. Valva a spoon-like concave structure, as in other species, but much more narrow and only slightly enlarged at the end. Ninth tergum almost non-developed. Uncus thick, rounded at top, less curved than in other species. Aedeagus straight, pointed, thicker than in Geina species.

General appearance and size similar to anisodactylus. Wing spread of lectotype I5 mm. Ground colour yellow, but appearing rather darker than anisodactylus as there is a characteristic greyish tint not apparent in that species.

Early stages. Corbett and Gates (I926) record this species from Malaya. According

I The capital letters after the locality on Meyrick's labels are the collector's initials and the figures following indicate the date (in this case 1888 ).

${ }^{2}$ Meyrick never indicated on his labels which specimens were types. 
to their data the larvae of zanclistes destroy the flowers of Vigna catjang Walp. (Leguminosae).

Geographical distribution. Lectotype was taken in the mountains of Burma. In Assam the species also appears in the mountains. The data concerning Ceylon, Malaya, and N. Australia should be verified.

\section{Genus Geina Tutt, I907}

Typus generis Phalaena Alucita didactyla, Linnaeus, I758 (= Petrophorus brunneodactyla Millière).

Geina Tutt, I907, Brit. Lep. 5: 4I I ('type didactyla Linn.') (non descr.).

Oxyptilus Z., Meyrick, I9I0, Wyts. Gen. Ins. 100: 6 ('= Geina Tutt') (partim).

Oxyptilus Z., Meyrick, I913, Cat. Lep. 17: 5 ('= Geina Tutt’) (partim).

Pterophorus Geoffr., Barnes and Lindsey, I92 I, Contr. Nat. Hist. Lep. Amer. 4: 297-298 ('= Geina

Tutt') (partim).

Oxyptilus Zeller, Fletcher, I929, Mem. Dep. Agric. India Ent. 11: 98 ('= Geina Tutt') (partim). Oxyptilus Z., Fletcher, I93I, Cat. Ind. Ins. 20: I2 (‘= Geina Tutt’) (partim).

Capperia Tutt, Adamczewski, 1939, Ann. Mus. Zool. Polon. 13: 263 ('= Geina Tutt') (partim).

Palpi without tuft of scales. Third feather of hind wing with a spot of scales at extreme end. Lateral edge of second lobe of fore wing distinctly cut out in a deep semicircle. Hind angle of fore wing very distinct. Aedeagus straight, strongly sclerotized, without appendages, not armed. Valva strongly sclerotized, narrow, bent at middle, sometimes with process at free end. Ninth tergum (male) very weakly developed. Ninth sternum (male) strongly developed as a large, heavily sclerotized plate terminating in two rounded flaps. Uncus well developed. Bursa copulatrix without signum. Ostium bursae not armed, weakly sclerotized.

The following species are included: didactyla Linnaeus, periscelidactyla Fitch, tenuidactyla Fitch (= cygnus Barnes and Lindsey = nigrociliatus Zeller, nec Walsingham), buscki McDunnough, and probably kuldschaensis Rebel. They are probably all oligophagous species. The genus was separated as distinct by Tutt (I907) for the palearctic species didactyla, but unfortunately not described. Meyrick resynonymized (IgI3) Geina with Oxyptilus Zeller. Also in error it was allied to the genus Capperia Tutt, from which it is distinct, as shown by the structure of the aedeagus, the ninth male sternum, and the second lobe of the fore wing.

This is an exclusively Holarctic genus.

\section{Geina didactyla (Linnaeus), I758}

(P1. Io, fig. 6; P1. I3, fig. 24; P1. I5, fig. 32)

P. [halaena] Alucita didactyla Linnaeus, I758, Syst. Nat. (ed. X), 1: 542 (partim).

P. [halaena] Alucita didactyla Linnaeus, 1761, Faun. Suec. 370.

Pterophorus 'primus', Schaeffer, I766, Icones Insect. Ratisb. pl. 93, fig. 7 .

'Phalene tipule', De Geer, I771, Mem. Hist. Ins. 2: 260-26r, pl. 4, figs. I-I r.

Alucita didactyla L., Denis and Schiffermüller, I775, Schmett. Wien, I45.

Phalaena Alucita didactyla Villers, I789, Linn. Faun. Suec. 2: 53I-532. ${ }^{\mathrm{I}}$

Amplyptilia trichodactyla, didactyla, chrysodactyla Schiff., Hübner, I826, Vevz. Bek. Schmett. 430, no. 4I $^{184}$ (partim). ${ }^{\mathrm{I}}$

Alucita didactyla Linn., Treitschke, I833, Ochsen. Schmett. Eur. 9: 237-238 (partim). ${ }^{\mathbf{1}}$

I Alucita trichodactyla Hübner (Samml. Eur. Schmett. figs. 9, I8 (I8oo-I8I3)), cited by Wocke, Rebel, Hofmann, Meyrick, and others as a synonym of didactyla Linnaeus, has nothing to do with this species. Hübner's fig. 9 is Oxyptilus chrysodactylus Denis and Schiffermüller (= hievacii Zeller) and fig. I8 is Capperia trichodactyla Denis and Schiffermüller (= leonuri Stange). 
Pterophorus didactylus Linn., Zeller, I839, Isis, 32: 275 (partim).

Oxyptilus trichodactylus Hbn., Zeller, 1852, Linn. Ent. 6: $353 .^{{ }^{\mathrm{I}}}$

Pterophorus trichodactylus Herrich-Schäffer, I854, Schmett. Eur. 5, Pter. tab. 3, fig. I3.

Pterophorus brunneodactyla Millière, 1854, Ann. Soc. Ent. France, (III), 2: 65-68, pl. 3, figs. 6-6a.

Oxyptilus trichodactylus Hbn., Herrich-Schäffer, 1855, Schmett. Eur. 5: 37I.

Pterophorus brunneodactyla Millière, Bruand d’Uzelle, I86r, Ann. Soc. Ent. France (IV), 1: 3536, pl. 2, fig. 8.

Pterophorus didactylus Linn., Schleich, I864, Stettin. Ent. Ztg. 25: 96-98.

Oxyptilus didactylus L., Wocke, Heinem, I876, Schmett. Deutschl. 2 (II) : 791-792 (partim). ${ }^{\mathrm{I}}$

Oxyptilus didactylus L., Hofmann, I896, Ber. Naturw. Ver. Regensburg. 5: I I4 (partim). ${ }^{2}$

Oxyptilus didactylus L., Rebel, I901, Cat. Lep. Pal. 2: 71 (partim).

Geina didactyla Linn., Tutt, 1907, Brit. Lep. 5: 4II. ${ }^{3}$

Oxyptilus didactylus L., Spuler, Schmett. Eur. 2: 324 (partim).

Oxyptilus didactylus L., Meyrick, I9ro, Gen. Ins. 100: 7 .

Oxyptilus didactylus Linn., Meyrick, I913, Lep. Cat. 17: 8 (partim).

Oxyptilus didactylus L., Hering, I932, Tierw. Mitteleuv., Ergänzbd. 1: 164.

Oxyptilus didactylus Linné, Lhomme, 1939, Cat. Lep. France, 2: i78.

Capperia didactyla (Linné), Adamczewski, 1939, Ann. Mus. Zool. Polon. 13: 26r.

In I758 Linnaeus erroneously cited the food-plant of didactyla and also mixed the bibliographical references concerning two species, but in I76I he corrected this mistake, writing that didactyla feeds 'Geo rivali'. In the photograph of the Plumes in the Linnean collection (W. H. T. Tams phot.), one specimen of a Geum-feeder was recognized, quite well preserved. Also examined was the type of brunneodactyla Millière, borrowed from the Natural History Museum of Paris. This specimen was labelled: 'Brunneodactyla Millière', 'Type', 'Coll. Mill.', 'Igor, coll. E. L. Ragonot, Muséum Paris'. It was a very well-preserved male of Geina didactyla Linnaeus. Millière described the form identical with didactyla as a new species because he doubtless used the work of Godart and Duponchel (I82I-I842, Hist. Nat. Lép. France, 4:3I3), wherein didactyla was wrongly figured with brushes of hairs on the end of abdomen. Obviously it was a species belonging to Oxyptilus or maybe Crombrugghia. Another strange mistake concerning the name brunneodactyla is shown in two specimens from the collection of Constant (L. Lhomme collection). One of them was distans Zeller, another pilosellae Zeller, but both bearing the name brunneodactyla (T. B. Fletcher in litt., I937). It is doubtful if these are the original determinations of Constant. The confusion over the name brunneodactyla was cleared up by Millière himself who synonymized his new species with didactyla (Catalogue Lep. Alpes Mar.: 380, 1875). Staudinger (I880) once more synonymized these two names (Horae S.E.R. 15: 425).

Denis and Schiffermüller (I775) enumerated three species of this group, 'didactyla L., trichodactyla, and chrysodactyla'. There is no doubt, however, that their 'didactyla L.' was not the Linnean species. Laspeyre (1805) stated that didactyla L. and didactyla D. \& S. were probably different species. Charpentier (I82I) considered the specimens of didactyla and chrysodactyla in Schiffermüller's collection as identical. It is very

${ }_{1}$ This part though dated 1877 was published not later than Nov. 1876 (see Kirby, I876, Zool. Rec. 13, (Ins.) 187 ).

2 The number of page taken from author's reprint having pagination pp. I-195; original pagination

is pp. 25-219; issued 1896 , not 1895 .

3 Issued 1907 , not 1906 .

ENTOM. I, 5 . 
probable that didactyla D. \& S. was an Oxyptilus species not described at that time, probably ericetorum or pilosellae but not the Linnean didactyla. Unfortunately Hübner, who did not know the Linnean species, synonymized all three species in the Wiener collection as trichodactyla and his mistake was followed by other entomologists. Hübner's figures of trichodactyla really represent chrysodactyla D. \& S. (Sammlung, fig. 9) and trichodactyla D. \& S. (Sammlung, fig. I8; Geschichte, figs. $2 a-b$ ) but not didactyla $\mathrm{L}$. as is wrongly cited by many authors. Treitschke also used the name didactyla L. wrongly for some different species, mainly for Capperia trichodactyla D. \& S., living on Leonurus, not on Geum. Zeller, who did not know the species living on Leonurus, determined his specimens of didactyla L. on Hübner's figure I8 of trichodactyla. However, Zeller's description and Herrich-Schäffer's figures of trichodactyla refer to the Linnean didactyla. Since Wocke's Catalogue (I876) the name didactyla L. has been correctly used for the Linnean Geum-feeder. The other so-called synonym of the Linnean species (see Oxyptilus chrysodactylus D. \& S.) was, in spite of Zeller's remarks (Isis, I84I: 88I-882), completely forgotten for one hundred years although it was the first name given for Oxyptilus hieracii Zeller.

Copulatory apparatus. Valva rounded at the end, not pointed as in American Geina (Barnes \& Lindsey, I92I, pl. 49). Aedeagus wider at the base, becoming much narrower at the end and more or less curved in the top part. Female copulatory apparatus of very simple structure. The plate of the ostium bursae symmetrical and more or less triangular, weakly sclerotized. Eighth sternum bluntly ended, not elongate. Bursa copulatrix without signum.

External appearance of the imago. Wing spread I8-23 $\mathrm{mm}$. The spot of scales on the third feather of hind wings is large and rectangular. The other feature distinguishing this species amongst the palearctic Plume-moths is the deep, semicircular cut in the second lobe of fore wings. Generally the species is brightly brown-rusty coloured.

Life-history. In the neighbourhood of Warsaw the larvae of didactyla were found on three plants: Geum rivale L., Geum urbanum L., and Potentilla rupestris L. Both Geum species grow in humid and shady places, but Potentilla rupestris is found in dry, sandy, and sunny spots. Colour of larva varies according to the food-plant. On Geum rivale larvae are greyish-pink, on Geum urbanum greyish-green, and on Potentilla rupestris light green. The larvae feed on flowers and flower-buds, from which the contents are eaten out through a hole made in the side of the bud. In default of flowers they feed on leaves. Hofmann (I896) mentioned also Veronica officinalis as a food-plant of didactyla, but the larvae kept on this plant in my breeding experiments died, refusing this food. Treitschke's data on Leonurus as a food-plant of didactyla refer to Capperia trichodactyla D. \& S. Experiments with Leonurus as a food-plant for didactyla larvae also resulted in failure. The larvae live during the month of May. The imago appears in June and July. There is one generation a year only.

Geographical distribution. Geina didactyla is recorded from nearly the whole of Europe except the British Isles, Iberian peninsula, and the Polar area. Outside Europe it is recorded only from Asia Minor. In several collections specimens from the central European countries and from France, Sarepta, and Asia Minor have been noted. 


\section{Geina kuldschaensis (Rebel), IgI4}

Oxyptilus kuldschaensis sp.n., Rebel, I914, Iris, 28: 272.

Oxyptilus kuldschaënsis Rbl., .Caradja, I920, Ibid. 34: 79.

Rebel described this species from one specimen from southern Turkistan (western part of Thian-Shan Mountains), captured in June. Caradja (I920) recorded it from the Alai Mountains (Fergana). There has been no opportunity to examine this species. According to Rebel's description it is very similar to didactyla and of the same size (wing spread $2 \mathrm{I} \mathrm{mm}$.). Rebel cited the following differences between this species and didactyla: lighter, and without black basal line in cilia; the third feather of secondaries is yellow in the middle, not white. Provisionally it is thought that kuldschaensis should be considered a Geina until the type, which is in the Caradja collection, can be more accurately examined.

Early stages and food-plant unknown.

Geographical distribution: Turkistan.

\section{Geina periscelidactyla (Fitch), 1854}

Pterophorus periscelidactylus Fitch, I854, Trans. N.Y. Agr. Soc. 14: 843.

Oxyptilus periscelidactylus Fitch, Walsingham, I88o, Pter. Calif. Oreg. 25: pl. 2, fig. 5 .

Sphenarches periscelidactylus Fitch, Walsingham, 1897, Proc. Zool. Soc. Lond. 1897: 57.

Oxyptilus periscelidactylus Fernald, I898, Pter. N. Amer. 17-18: pl. 2, figs. 3-4; pl. 5, figs. I-2. Sphenarches periscelidactylus Fitch, Walsingham, I898, Ent. Mon. Mag. 1898: I92.

Pterophorus periscelidactylus Fitch, Barnes and Lindsey, I921, Contr. Nat. Hist. Lep. Amer. 4: 299-30r, pl. 4I, fig. 4 ; pl. 49, fig. 5 .

Pterophorus periscelidactylus Fitch, McDunnough, I927, Trans. Roy. Soc. Can., sect. V, 1927: I76, pl. I, fig. 2.

Walsingham placed this species in the genus Sphenarches $(\mathrm{I} 897, \mathrm{I} 898)$. As a matter of fact the genus Geina is nearer to Sphenarches than to Oxyptilus, but Geina constitutes a quite distinct taxonomic group which cannot be united with any other genus and which was correctly separated by Tutt (I907). This species was not closely examined, only the series of Walsingham specimens in the British Museum was seen. These specimens are similar to didactyla but much brighter, clear browncoloured without rusty tint, and mostly smaller than the European species. They vary much in size. According to Barnes and Lindsey (I92I) the wing spread is I6-20 $\mathrm{mm}$. but Fernald (I898) gives a range of $\mathrm{I} 4-29 \mathrm{~mm}$.

The geographical distribution of periscelidactyla seems to be very wide because it is recorded both from Canada (McDunnough, F926) and from the Southern States of U.S.A. (Fernald, I898, and Walsingham, I880).

The larvae are known as pests of grapes (Vitis vinifera). Whitcombe, Tomlinson, and Guba write that this species feeds on wild and cultivated forms of Vitis labrusca (Bull. Mass. Agric. Exp. Sta. 409: I943).

Fernald (I898), Barnes and Lindsey (I92I), and McDunnough (I927) published the figures of male copulatory apparatus of this species, but the drawings of the abovementioned authors differ from each other. Possibly there exists more than one species under the name periscelidactyla. This group should be more accurately revised 
and the copious data from the literature referred to by Barnes and Lindsey (I92I) should be verified.

\section{Geina tenuidactyla (Fitch), I854}

Pterophorus tenuidactylus Fitch, I854, Trans. N.Y. Agr. Soc. 14: 848.

Oxyptilus nigrociliatus sp.n., Zeller, I873, Verh. Zool. Bot. Ges. Wien, 23: 322-323.

Oxyptilus tenuidactylus Fernald, I898, Pter. N. Amer. 20: pl. 6, figs. 4-6 (partim).

Pterophorus cygnus sp.n., Barnes and Lindsey, I92 I, Contr. Nat. Hist. Lep. Amer. 4: 304, pl. 49, fig. 2.

Pterophorus tenuidactylus Fitch, Barnes and Lindsey, I92I, Ibid. 4: 30I-303 (partim).

Pterophorus cygnus B. \& L., McDunnough, I923, Canad. Ent. 55: 85.

Pterophorus cygnus B. \& L., McDunnough, I933, Ibid. 65: 205-206.

Owing to the great similarity of tenuidactyla Fitch and buscki McDunnough these two species are always mixed in the literature. On external appearance they differ from each other in colour; buscki is clearer reddish-brown and tenuidactylus is darker chocolate-brown. In the copulatory apparatus they are distinct but similar. These two species are distinguished by their ecology, living on different plants. The geographical distribution is similar-both species being recorded from Canada and U.S.A. Zeller (1873), describing his nigrociliatus, which is a synonym of tenuidactyla, added the following remarks: 'Lobidactylus Fitch soll grösser sein als tenuidactylus (Flügelspannung 0,80 gegen 0,60 ; bei periscelidactylus 0,85 ), und kann also schon darum nicht einerlei mit nigrociliatus (vorderflügel $3^{\prime \prime \prime}$ lang) sein. Ohne Zweifel giebt es in Nordamerika mehr Oxyptilus-Arten, als Fitch unterscheiden zu können glaubte.' Walsingham ( 1880 ) gives under the name nigrociliatus $Z$. a series of specimens from California (see buscki McD.). These specimens were examined in the British Museum and amongst them were observed three specimens a little darker than others from the same localities. This species was sent by Walsingham for determination to Zeller, who considered it as nigrociliatus. It is assumed that just one of these darker specimens was seen by Zeller and from his determination resulted the erroneous interpretation of the synonymy of this group by Walsingham and Fernald. Both Walsingham and Fernald distinguished the as yet undescribed buscki from tenuidactyla, but they wrongly named it nigrociliatus, which, of course, is a synonym of tenuidactyla. Fernald (I898) gives figures of male copulatory apparatus of the type of tenuidactylus Fitch. Thanks to these drawings it is possible to fix the proper synonymy. On the other hand, Fernald states that he did not find any difference in the structure of the copulatory apparatus between Fitch's type and paler Californian specimens, which Walsingham published as nigrociliatus $Z$. Fernald's opinion is not decisive in this case because his method of examining the genitalia was very primitive and, dealing with two very similar species, he could obtain no other result. As we see from his drawings, he used the same methods as Hofmann, who could not distinguish the genitalia of such distinct species as Capperia trichodactyla and fusca (I898) or Capperia lorana and britanniodactyla (I896). Thus it happened that Fernald established quite by chance the proper synonymy of tenuidactyla Fitch (= nigrociliatus Zeller). There is no doubt that Zeller's cotype in the U.S.A. National Museum and Fitch's authentic specimen both belong to the above-mentioned darker form and have identical genitalia (see Busck in McDunnough, I933). The type specimen of nigrociliatus Zeller (from Dela- 
ware), which is present in the British Museum, belongs also to the darker form and is distinct from Walsingham's Californian specimens. Unfortunately Zeller's abovementioned type had lost its abdomen and therefore it was impossible to see the pattern on the abdomen in which Barnes and Lindsey (I92I) found some differences between tenuidactyla and cygnus. Described by Barnes and Lindsey (I92I), the new species cygnus was based mostly on the differences in the genitalia of one worn specimen. This new species corresponded to the above-mentioned paler form not yet described. Unfortunately Barnes and Lindsey caused even greater confusion as they published by mistake the figure of the genitalia of the new species under the name of tenuidactyla and vice versa. In this way they added the new synonym cygnus for the darker form and the lighter one still was undescribed. This mistake was discovered by McDunnough (I923). In I933 Busck gave (in litteris) the explanation of this confused synonymy (see McDunnough, I933) and at the same time the paler coloured form was at last described as buscki McD.

The male copulatory apparatus of Geina tenuidactyla Fitch is represented by the figure of Barnes and Lindsey (I92I) under the name of Pterophorus cygnus (1.c., pl. 49, fig. 2) and the figures of Fernald (I898) under the name of Oxyptilus tenuidactylus (1.c., pl. 6, figs. 4-6).

Geina tenuidactyla Fitch lives in the single generation on 'thimbleberry' (Rubus parviflorus Nutt. $=R$. nuttkans). McDunnough (I933) cited also 'strawberry' (Fragaria sp. ?) as a food-plant. The oligophagous character of the species belonging to the genus Geina makes possible the appearance of tenuidactyla also on 'blackberry' (Rubus sp.), which probably is a food-plant of the allied Geina buscki. It is better in this case not to base the determination of a species on its food-plant. Further ecological investigations are needed here.

Until the American data are greatly amplified we cannot obtain much information as to the geographical distribution of this species. The verified data record Geina temuidactyla from Canada (McDunnough) and from north-eastern U.S.A. (Fitch, Zeller).

\section{Geina buscki (McDunnough), I933}

Oxyptilus nigrociliatus Z., Walsingham, I88o, Pter. Calif. Oreg. 31: pl. 2, fig. 8.

Oxyptilus tenuidactylus Fitch, Fernald, I898, Pter. N. Amer. 20: pl. 6, figs. 4-6 (partim).

Pterophorus tenuidactylus Fitch, Barnes and Lindsey, I92 I, Contr. Nat. Hist. Lep. Amer. 4: 30 I303, pl. 49, fig. I (partim).

Pterophorus buscki sp.n., McDunnough, 1933, Canad. Ent. 65: 206.

Very similar to the preceding species but clearer coloured. The data from literature under the name of tenuidactyla partially refer to Geina buscki, but all the material needs revision. It is possible that all data concerning the specimens of nigrociliatus or tenuidactyla, bred on blackberries (Rubus sp.) also refer to Geina buscki. The specimens of nigrociliatus recorded by Walsingham (I880) from California most probably belong to buscki.

The male copulatory apparatus was, according to Busck (see McDunnough, I933), represented by Barnes and Lindsey (I92I) under the name of temuidactyla (1.c., pl. 49, fig. I). 
Probably widely distributed species in Canada and U.S.A., but at present the only verified records are from Canada (McDunnough, I933).

\section{Genus Procapperia gen.n.}

Typus generis Oxyptilus maculatus Constant, $\mathbf{1} 865$.

Palpi without tuft of scales. Spot of scales of the third feather of hind wings is remote from its end but nearer the end than in the genus Crombrugghia. The lateral edge of the second lobe of the fore wings very slightly curved, nearly straight. The hind angle of fore wings very weakly marked. Aedeagus strongly S-like curved, strongly sclerotized, bilaterally symmetrical but without any appendages such as processes or spines. Valva slightly arched, more strongly sclerotized in the basal half than in the distal half. The distal half of the valva enlarging in the form of a more or less oval flap having no folds or appendages. The ninth tergum pointed as in the genus Capperia but less developed. Uncus hidden under ninth tergum and very weakly developed. The ninth sternum in the form of a plate having its hind edge bifurcate and tucked up forwards. The ninth sternum short, reaching to one-third of the length of valva only. The ninth sternum (male) in its vesicular structure is similar to Sphenarches, but it is obviously developing to become a plate as in Capperia. Bursa copulatrix without signum. The ventral plate of eighth sternum at ostium bursae is formed like an irregular triangle a little more strongly sclerotized at its top, but otherwise having no characteristic features.

The genus is represented in the Mediterranean and Indo-Australian faunas. To it belong the following species: maculata Constant, linariae Chrétien, croatica sp.n., anatolica Caradja, and pelecyntes Meyrick. Probably all monophagous.

These species are distinguishable by their external appearance. According to the structure of copulatory apparatus they form two distinct groups, one Mediterranean, the other Indian. The species of the first group are all very similar in their copulatory apparatus. They cannot, however, be considered as forms of one species only, because of the considerable differences in the size and colour between maculata, linariae, and anatolica. The very distinct looking croatica could not be considered as a form of any previously described species and it has therefore been provisionally established as another species in this group, in order to complete the materials for further investigations. The collection of more ecological observations and also some data on the morphology of early stages are needed in order to show the most characteristic features of these forms. The group is an especially interesting subject for investigation because the differences that already exist are weak. It is a group of species in statu nascendi, providing for further investigators the chance of studying the causes of specific differentiation. It would be also very interesting to relate their taxonomic status with the evolutionary stage they have reached.

\section{Procapperia maculata (Constant), I865}

(P1. I0, fig. I2; Pl. I2, fig. 20 ; Pl. I4, fig. 28)

Oxyptilus maculatus Constant, 1865, Ann. Soc. Ent. France, 34: 193-194, pl. 7, fig. 9.

Oxyptilus maculatus Const., Wocke, 1876, Heinem. Schmett. Deutsch. 2: 792.

Oxyptilus maculatus Const., Staudinger, 188o, Horae Soc. Ent. Ross. 15: 425-426.

Oxyptilus kollari Sta., Frey, 188o, Lep. Schweiz: 429.

Oxyptilus? maculatus Const., Rebel, I9or, Cat. Lep. Pal. 2: 71.

Oxyptilus maculatus Constant, Meyrick, 1913, Lep. Cat. 17: 6.

Oxyptilus maculatus Const., Caradja, 1920, Iris, 34: 5 . 
Oxyptilus maculatus Cst., Chrétien, 1922, Étud. Lep. Comp. 19: 339.

Oxyptilus maculatus Constant, Lhomme, 1939, Cat. Lep. France, 2: 178.

Capperia maculata Const., Adamczewski, 1939, Ann. Mus. Zool. Polon. 13: 26r.

Original description: 'Envergure, 20-23 mill. Ailes supérieures d'un brun jaunâtre, avec deux bandes transversales obliques et parallèles d'un blanc sale, sur chacun des deux lobes. Un trait transversal blanc, ombré de brun du côté interne, situé au point précis où l'aile se partage, et se prolongeant obliquement, par sa partie inférieure, jusqu'à la première bande blanche de la seconde division de l'aile. Frange entrecoupée de roux et de blanchâtre, avec çà et là quelques traits noirs le long du bord interne. Ailes inférieures d'un gris brun, avec la frange un peu plus foncée; troisième lobe à nervure blanche, avec une tache noirâtre, éclairée inférieurement de blanc, vers les deux tiers de sa longueur. Dessous des quatre ailes de la même couleur que le dessus, avec les mêmes dessins, sauf que le premier lobe des secondes ailes est ordinairement lavé de blanc. Tête et thorax jaunâtres; collier et ptérygodes blanchâtres. Antennes finement annelées de brun et de blanc. Abdomen roux; partie inférieure des anneaux ciliée de poils blancs dans toute sa circonférence, surtout chez la femelle; pointe anale de cette dernière marquée en dessus de deux traits blancs, rectilignes, longitudinaux et parallèles. Cuisses et tibias blancs en dedans, roux en dehors; articles des tarses roux, avec leur partie antérieure blanchâtre; éperons blancs, à pointe brune. Basses-Alpes, en juin et juillet.'

Examined material:

I. Two original specimens of Constant from Basses-Alpes, borrowed from L. Lhomme, bearing following labels : $0^{\star-}$ - Constant, maculatus' and a small triangular label, dark-lilac coloured; 우-'Coll. Constant, Oxyptilus maculatus', 'I9' and a small, triangular, yellow-coloured label.

2. Male specimen from southern France (Hautes-Alpes), borrowed from T. B. Fletcher: 'La Grave 6.viii.r 896, Tutt Coll.' , '2367, Wlsm. I896', 'Oxyptilus hieracii Z., named by Wlsm.'.

3. Female specimen from Italian Alps (British Museum (N.H.)): 'Frey Coll. Brit. Mus. I 890-62', 'P. Kollari ? Z., Distans ? Z., Aosta', and 'I947/7I' (genit. praep.).

Male copulatory apparatus. Valva slightly arched, flat, without folds and appendages. From the middle of its length the valva expands in the form of an ellipsoidal plate, rounded at the top. Aedeagus S-like curved, bilaterally symmetrical, without appendages. The ninth tergum pointed. The ninth sternum having two end flaps tucked up and turned forwards. It is a short, thick vesicular organ reaching only onethird of the length of the valva.

Female copulatory apparatus. The eighth sternum in the form of an irregular, triangular plate having its back top a little more sclerotized than other parts. Through this plate there is visible the end part of the ductus bursae in the form of a small elongated point, strongly sclerotized. There are no other characteristic features or appendages. Bursa copulatrix without signum.

External appearance. This is one of the largest species of the genus. Wing spread of examined specimens from I9-2I mm. (ㅇ) to $20-22 \mathrm{~mm}$. ( $\mathrm{d}^{\mathrm{C}}$ ). The spot of scales is not at the end of the third feather of the hind wing but very near to it and appears as a small weakly defined patch, existing chiefly on back edge of the feather. On its fore edge appear only a few single dark scales. Also a few single dark scales are present on the top of third feather. The middle and end parts of the third feather are white. The ground of fore wings dark brown with greyish tint. The lateral edge of the second lobe of fore wings very weakly curved, nearly straight. The hind angle of fore wing very weakly marked.

Constant described this species from Basses-Alpes. Caradja (I920) knew it in a 
series of specimens from La Grave (Hautes-Alpes). Caradja emphasized the similarity of maculata and hoffmannseggi. Really it is only a superficial similarity in colour to the dark coloured Asiatic specimens of hoffmannseggi and it is not, at present, certain that the latter are the same species as the lighter coloured specimens from Spain, whence hoffmannseggi was described. Further, hoffmannseggi belongs to the genus Oxyptilus and can easily be distinguished from maculata by the generic features. The best character for distinguishing hoffmannseggi from other species at first sight is its white cilia on the very top of the third feather of the hind wings, in both Spanish and Asiatic specimens. Caradja considered that Constant's original figure of maculata was nearly perfect. The figures in Constant's publication were painted by hand and therefore they probably differed in various copies of the same publication. The copy I used was probably not so carefully painted as Caradja's, because I could not identify with certainty the original specimens of Constant with his figure of maculata. Caradja considered too that maculata was closely allied to 'Oxyptilus hieracii'. This is a very strange view: there is not one important character common to Procapperia maculata Const. and Oxyptilus chrysodactylus D. \& S. (= hieracii Z.). It is possible that Caradja had wrongly named hieracii. Some earlier entomologists (Greening, Knaggs, Jordan, Stainton, Frey, and others) used to apply the name hieracii to Capperia britanniodactyla Gregson and in this case the similarity to maculata is understandable as the genera Capperia and Procapperia are nearly related but both very far from Oxyptilus.

Geographical distribution. Basses-Alpes (Constant), Hautes-Alpes (Caradja and Tutt's specimens from Fletcher's collection), Italian Alps (Zeller's specimen from Aosta, recorded by Frey (I880) as kollari, now in the British Museum), Pyrenees (fide Lhomme, I939).

Time of appearance. June, July, and August. Obviously two generations, as may be seen from the male specimen of 6 August quite fresh and unworn.

Life-history. Chrétien (I922) gives some ecological data and describes the pupa. He writes that the larvae of maculata appear in the Hautes-Alpes in June feeding on Scutellaria alpina.

\section{Procapperia linariae (Chrétien), I922}

(P1. 20, fig. 6I)

Oxyptilus linariae sp.n., Chrétien, I922, Étud. Lep. Comp. 19 (I) : 338-340, pl. DxLvi, fig. 4602. Oxyptilus linariae Chrétien, Powell, I922, Ibid. 19 (II) : 87.

Chrétien's description of this species is based on the single male specimen bred on Scutellaria (see Powell's remarks) but bearing an erroneous name of the food-plant on its label. This specimen (not designated as type) is in the British Museum and bears the following labels: 'Oxyptilus linariae sp.n.', 'Maroc, Timhadit, Harold Powell, Août I920', 'Timhadit, éclosion du 23.8.I920, Chenille sur Linaire à feuilles crénelées. Août.' and 'I947/12' (praep. genit.).

Below is quoted the original description of Chrétien and Powell's supplementary corrections published by Oberthür.

Original description: 'Un sujet $\widehat{o}$ obtenu de "chenille vivant sur une Linaria à feuilles crénelées” à Timhadit, en août 1920 (Powell). I7 mm. Ailes supérieures brun jaunâtre ou roux, 
parsemées de fines écailles blanches dans la partie antérieure ou costale; la côte brun noir entre les taches et blanche à la partie apicale; une tache blanche dorsale au quart, précédée de brun roux foncé; une petite tache blanche antémédiane sur la disque, précédée d'un gros point brun noir; une strie blanche sur la bifurcation et deux stries transversales obliques blanches sur les lobes, se continuant dans les franges, mais en sens inverse, la première plus large; vers la côte, ces stries sont bordées de noir, la première extérieurement, la deuxième intérieurement. Franges brunes, entremêlées d'écailles noires et blanches; quatre petites mèches noires sur le bord postérieur du deuxième lobe.

'Ailes inférieures: les deux premières divisions brun roux, avec les franges brunes; la troisième division est légèrement marquée de blanc sur le bord antérieur, avant et après le petit groupe d'écailles noires qui sont presque d'égale longueur sur les deux bords et s'étendent assez près de l'apex. Franges brunes, portant quelques écailles noires réparties entre la base et le groupe d'écailles noires.

'Dessous brun roux, avec les taches blanches du dessus.

'Tête et thorax de la couleur des ailes supérieures; antennes annelées de brun roux foncé et de blanc, palpes brun roux ou noir, l'extrémité des articles marquée de blanc, le dernier à peine ; abdomen brun jaunâtre roux, parsemé d'écailles brun roux foncé ou noir; l'extrémité des segments à écailles saillantes blanc crème; partie anale brun jaunâtre; pattes blanc crème, plus ou moins garnies d'écailles brunes ou noires, formant des lignes longitudinales sur les tibias, des taches sur les tarses; éperons blancs, à extrémité brune.

'Espèce voisine d'Ox. maculatus, Cst., plus que de toute autre. Je me suis peut-être étendu trop longuement dans la description qui précède: c'était cependant nécessaire, car, pour tâcher de séparer des espèces si voisines entre elles, où quelquefois il ne peut être question que du plus ou moins d'apparence dans les caractères, il importe de ne négliger aucun détail. Encore ne réussit-on que difficilement. Mais ce qui doit entraîner et assurer la conviction, c'est la nourriture de la chenille.

'La chenille d'Ox. maculatus, Cst. n'a pas été décrite; personne n'a dit l'avoir découverte et en avoir obtenu le papillon que le Catalog de rgor considère comme espèce douteuse. Cependant, je la connais depuis de longues années; elle vit sur la Scutellaria alpina en juin, dans les HautesAlpes. Les papillons obtenus ont été soumis à Constant lui-même, qui a reconnu son maculatus. Leur détermination ne peut donc en être suspecte.

'La dépouille de la chrysalide d'Oxypt. linariae a la forme des chrysalides d'Oxyptilus: métathorax surélevé, avec dépression longitudinale des deux versants; extrémité des enveloppes libre; elle est grise, avec une bande dorsale plus foncée, des sous-dorsales bien moins distinctes; thorax finement chagriné garni de poils courts, au sommet, plus longs et à extrémité courbe en avant; segments de l'abdomen finement plissés transversalement sur les dos; les verruqueux de la chenille sont représentés par deux petits tubercules externes à poils étoilés, les plus longs inclinés horizontalement, l'un en avant, l'autre en arrière, et deux ou trois points internes portant un poil; ptérothèques gris brun, à nervures saillantes, brun foncé et garnies de cils en ligne et dirigés en arrière; cératothèques ciliés dans toute leur longueur; stigmates brun noir, peu distincts, dans une petite dépreșsion concave; mucron prolongé en bec plat, dont l'extrémité est garnie de soies raides, à crochets.

'La chrysalide d'Ox. maculatus est gris clair; ptérothèques gris foncé, la dépression longitudinale plus creuse, les poils du mésothorax plus longs; les stigmates plus distincts, le mucron plus anguleux.

'Ox. hieracii, Z., a une teinte plus claire avec une large bande dorsale brun foncé.

'Ox. teucrii, Jordan, a des poils plus longs encore sur le mésothorax; les ptérothèques grises comme les nervures; le mucron plus anguleux.

'Inutile de parler des chrysalides d'Ox. tristis, distans, laetus, espèces vivant sur les Composées.

'La chenille d'Ox. didactylus a bien été trouvée aussi sur une Scrophulariée; mais il ne peut venir à l'esprit de comparer Ox. linariae à didactylus, à cause des trop grandes différences de la troisième division de leurs ailes inférieures.'

H. Powell's remarks on linariae:

'C'est par erreur que l'étiquette piquée à l'épingle de l'Oxyptilus obtenu d'éclosion à Timhadit, ENTOM. I, 5 . 
en août I920, indique, comme nourriture de la chenille, une Linaria. La plante n'est pas une Linaire, mais une Labiée, la Scutellaria Demnatensis. Si M. Chrétien n'avais pas été trompé par l'étiquette erronée, il aurait, peut-être, rattaché l'Oxyptilus linariae à O. maculatus Constant, dont la chenille vit également sur une Scutellaria ?'

Powell is wrong in his supposition. Chrétien described linariae as a new species not only because it was an ecologically distinct form but also because he knew how different it was in external appearance from maculata which he bred in the Alps. If Chrétien had known the proper food-plant of linariae he certainly would have described this species as distinct from maculata.

The copulatory apparatus of linariae is very similar to that of maculata. The valva a little wider and its end part more nearly triangular than elliptical as in maculata. The other parts very similar in both species.

In external appearance the specimen of Chrétien differs in colour and size from maculata; it is much smaller (wing spread $\mathrm{I} 7 \mathrm{~mm}$.) and much clearer coloured. The ground colour of fore wings is light brown with a yellowish tint, not dark brown as in maculata.

Life-history. Chrétien emphasized the ecological distinctness of linariae and maculata, but he did not know that Linaria was erroneously noted as food-plant of linariae. However, he was right because linariae and maculata breed on two distinct foodplants. Procapperia linariae Chrétien lives on Scutellaria demnatensis. Larvae appear in August, imagines at the end of this month. Doubtless there are at least two generations.

Geographical distribution. Morocco.

\section{Procapperia croatica sp. n.}

$$
\text { (P1. I0, fig. II; P1. I2, fig. I8; Pl. I4, fig. 27) }
$$

Examined material:

I. Three specimens from Schawerda Collection (Deutsches Kolon. Museum, Bremen):

a. $\widehat{0}$, 'Zengg, Kroatien, 22 Juni I9I7' (Holotype).

b. ㅇ. 'Zengg, Kroatien, I4 Jun. I9I7' (Allotype).

c. ㅇ, 'Zengg, Kroatien, 6.6.19I7', 'Oxyptilus marginellus Z.' (det. Rebel) (paratype).

2. Five specimens from Dobiasch Collection (Magyar Nemzeti Museum, Budapest):

a. Four specimens '22-23.vi.I918, Zengg, Kroatien, Dobiasch' (paratypes).

b. Male specimen '24.vii.I918, Zengg, Kroatien, Dobiasch' (paratype).

Male copulatory apparatus (slide no. Ox. 83) very similar to maculata. Valva slightly arched, flat, from the middle to the end enlarged in the form of a flap, not rounded at the top as in maculata, but nearly pointed. No folds or appendages on the valva. Aedeagus S-like curved, similar to maculata but a little weaker, bilaterally symmetrical. The ninth sternum very similar to maculata but seems a little longer. The female copulatory apparatus (slide no. Ox. Ioo) very simply built, without any characteristic parts, even at ostium. Ostium bursae only a little more sclerotized than ductus bursae, scarcely visible under eighth sternum.

External appearance. The smallest species in the Mediterranean group of this genus. Wing spread I4-I6 mm. Its small size distinguishes it from other species, as well as the colour, which is greyish-yellow. From linariae it is distinct, having no vivid light 
brown colour. Also it has no bright, vivid white pattern as in anatolica. The clear white pattern present in croatica appears only in cilia of fore wings except for some pattern on the wing surface which is whitish passing into light-yellowish. The black pattern is more apparent in croatica than in allied species. On the hind edge of the fore wings there are very distinct tufts of black scales. Palpi without tuft of scales. The spot of scales on the hind wings remote from the end of the third feather, not reaching the very top of it.

Early stages and food-plant unknown. There are two generations.

Geographical distribution. Southern Croatia. ${ }^{\mathrm{I}}$

Holotype and one paratype-Colonial Museum, Bremen.

Allotype and five paratypes-Polish Museum of Zoology, Warsaw.

\section{Procapperia anatolica (Caradja), I920}

Oxyptilus anatolicus sp.n., Car., I920, Iris, 34: 79.

Examined material:

I. One $\widehat{\jmath}$ specimen (Magyar Nemzeti Museum, Budapest): 'Asia Min., Amasia I888, Korb, marginellus, coll. Eppelsheim'.

2. One đิ specimen (British Museum, London): 'Taurus Mts., Asia Minor, J., o6', 'Oxyptilus laetus Z., E. Meyrick det. in Meyrick coll.', 'I947/2' (genit. praep.).

3. Three specimens ( $\widehat{\sigma}$ and 2 우) from Georgia (British Museum, London): 'Kutais, Gagry, Paravicini', '7.8.12', 'Paravicini Coll. B.M., 1937-383' (placed in the B.M. Collection as linariae).

Original description. 'Zusammen mit voriger fing M. Korb bei Ak Chehir im Juli sechs Stücke ot 으, die sich von distans-laetus durch folgende wichtige Merkmale leicht und sicher unterscheiden: Von kleinerem Ausmass und bräunlichgrauer Grundfarbe, sind die lichten Zeichnungen und Flecke auf dem Vorderzipfel der Vfl. rein weiss, breiter und schärfer abgegrenzt; die zwei äusseren weissen Querlinien sind näher am Apex und auch dichter aneinandergerückt. Die dritte Feder der Hfl. ist weiss mit grauen Fransen. Beine und Schienen weiss mit spärlicher brauner Ringelung. Auch Lord Walsingham hielt die Art für neu.'

Male copulatory apparatus (slide no. I947/2) very similar to maculata. The only difference appears to be in the valva, which is more elongated and a little narrower.

External appearance. Wing spread: $16 \mathrm{~mm}$. (Taurus), I7 mm. (Kutais), I $8 \mathrm{~mm}$. (Amasia). This species distinguished by very vivid white pattern on the fure wings. The specimens from Taurus and Amasia were dark yellow in the pure vivid colour without grey or brown tint. The specimens from Kutais are darker, with yellow colour passing into brown similar to linariae, from which it is distinct by its vivid white pattern. Probably the brownish specimens of Caradja correspond to the specimens from Kutais. The spot of scales remote from the end of the third feather. According to the description of Caradja the third feather seems to be white owing to the presence of numerous white scales along the surface of the feather and in its cilia.

Early stages and food-plant unknown. Imagines known in July and August. Doubtless two generations occur.

I Rebel (Rovartani Lapok, 23: II7) recorded a series of 'Oxyptilus teucrii Jord. var. loranus Fuchs' from Zengg, 25.v-6.vi, Dobiasch coll. It is very probable that these specimens were also croatica. 
Distribution. Asia Minor (Ak Chehir, Amasia, Taurus Mts.) and Georgia (Kutais).

\title{
5. Procapperia pelecyntes (Meyrick), I908
}

\author{
(P1. 20, fig. 60)
}

Oxyptilus pelecyntes sp.n., Meyrick, I908, Trans. Ent. Soc. Lond. 190': 477.

Oxyptilus pelecyntes Meyr., Meyrick, 1913, Lep. Cat. 17: 6.

Oxyptilus pelecyntes Meyr., Fletcher, I921, Mem. Dep. Agric. India Ent. 6: r4.

Oxyptilus pelecyntes Meyrick, 1935, Caradja's Mat. Microlep. Faun. Chinas Prov. 45.

Examined material:

I. A series of males and females from Ceylon (British Museum (N.H.), London). Genitalia were prepared from a male labelled as follows: '8426, Ceylon, Haldommulla, 8.7.1909, 2800 ft., W.O.'; 'Walsingham collection, B.M. I910-427', 'Oxyptilus pelecyntes Meyr.' and ' $1947 / 58$ ' (genit. praep.).

Original description. ' Antennae white lined with black. Thorax dark fuscous, with an ochreous-white posterior spot. Abdomen ochreous brown streaked with blackish, margins of segments mixed with white, with an ochreous-white basal patch. Legs white, anterior and middle pairs lined with black, posterior pair banded with black. Forewings cleft from middle, segments narrow, apex of second longproduced, slender, termen concave; dark reddish-fuscous, sprinkled with whitish-ochreous ; first segment with a small white spot on base of lower margin, and two slender undefined somewhat inwardly oblique white bars at $\frac{1}{3}$ and $\frac{2}{3}$; second segment sometimes with a few scales at base and blackish patches before and between bars, in cleft grey with scattered black scales, on dorsum ochreous-white with a black scale-tooth before cleft, others at $\frac{1}{4}$ of second segment and apex, and a grey patch mixed with black midway between these. Hind-wings cleft firstly from about $\frac{1}{3}$, secondly from near base, segments linear; dark fuscous; cilia dark grey, on dorsum with two or three scattered black scales, and a moderate black scale-projection at $\frac{4}{5}$ of third segment, marked with some black scales on upper side also. Assam (Khasi Hills) in April and September; three specimens.'

External appearance. Wing spread I2-I4 mm. The ground colour of wings dark rusty-brown. The cilia shorter than in Mediterranean species and because the feathers seem to be more separated from each other the specimens seem to be more delicate. The lateral margin of the second lobe of fore wings more strongly cut out than in Mediterranean species. Palpi without tuft of scales. The spot of scales removed inwards from the end of third feather to more or less $\frac{1}{4}$ of the length of this feather. On the top of third feather a few single dark scales.

The male copulatory apparatus. Aedeagus less strongly S-like curved than in Mediterranean species. Valva similar to maculata but straight, not arched, and very hairy on inner surface. The ninth sternum shorter than in maculata and very distinctly bifurcate at its end. The ninth tergum very elongate, triangular. Uncus very weakly developed.

Fletcher (I92I) cited Scutellaria discolor as a food-plant of pelecyntes.

Early stages unknown. Imagines appear in April and September (Assam) and in July (Ceylon). Most probably more than two generations.

Geographical distribution. India (Assam) and Ceylon. Also recorded from Hunan Province in China (Meyrick, I935). 
IV. Genus CAPPERIa Tutt, I907

Typus generis: Oxyptilus britanniodactylus Gregson, I869 (= heterodactyla Tutt, nec Müller, nec Villers).

Capperia Tutt, 1905, Ent. Rec. 1\%: 37 (non descr.).

Capperia Tutt, 1907, Brit. Lep. 5: 470-47I (type: heterodactyla).

Oxyptilus Z., Meyrick, I910, Gen. Ins. 100: 6 (= Capperia Tutt) (partim).

Oxyptilus Z., Meyrick, I913, Cat. Lep. 1\%: 5 (= Capperia Tutt) (partim).

Pterophorus Geoffr., Barnes and Lindsey, I921, Contr. Nat. Hist. Lep. Amer. 4: 297-298 (= Capperia Tutt) (partim).

Oxyptilus Zeller, Fletcher, 1929, Mem. Dept. Agric. India Ent.11: 39 (=Capperia Tutt) (partim). Oxyptilus Z., Fletcher, I93I, Cat. Ind. Ins. 20: I2 (= Capperia Tutt) (partim).

Capperia Tutt, Adamczewski, 1939, Ann. Mus. Zool. Polon. 13: 263 (partim).

Palpi without tuft of scales. Third feather of hind wing with a spot of scales at its end. Lateral margin of second lobe of fore wing slightly and indistinctly arched. No distinct tuft of scales on end of abdomen.

Aedeagus very strongly S-like curved $^{\mathrm{I}}$ and strongly sclerotized, armed with appendages, often bilaterally asymmetrical. Valva elongated, very strongly sclerotized, provided with folds, flaps, or processi. The ninth tergum weakly sclerotized, forming a triangular flap covering the weakly formed uncus. The ninth sternum strongly sclerotized and in the form of a large plate reaching top of valvae and ending in a pointed bifurcation. ${ }^{I}$ Bursa copulatrix without signum. Ostium bursae strongly sclerotized, armed with specific appendages. Sometimes the lamella antevaginalis appears as a strongly sclerotized plate covering ostium bursae from ventral side.

This is one of the most specialized genera both morphologically and ecologically. Here belong the following species: (I) britanniodactyla Gregson (= teucrii Jordan, = heterodactyla auct. nec Villers, nec Müller), (2) celeusi Frey (= intercisus Meyrick), (3) washbourni n.sp., (4) ningoris Walsingham, (5) evansi McDunnough, (6) trichodactyla Denis et Schiffermüller (= leonuri Stange = affinis Müller-Rutz), (7) fusca Hofmann, (8) fusca Hofmann n. forma marrubii, (9) tamsi n.sp., (Io) raptor Meyrick, (II) hellenica n.sp., (I2) lorana Fuchs, (I3) marginella Zeller, (I4) zelleri n.sp., (I5) polonica n.sp., (I6) maratonica n.sp., (I7) fletcheri n.sp., (I8) geodactyla Fuchs. This genus was created by Tutt for heterodactyla (= britanniodactyla Gregson) with its two 'variations': lorana and celeusi, and for leonuri (= trichodactyla D. \& S.). It was wrongly synonymized by Meyrick with the genus Oxyptilus Z. from which it is very distinct morphologically and ecologically. All the species of the genus Capperia are monophagous, feeding exclusively on plants belonging to the family Labiatae. All have two generations a year wherever they occur, regardless of differences in climate.

Distributed in the Holarctic region only.

\section{Capperia britanniodactyla (Gregson), I869}

(P1. Io, fig. Io; P1. I3, fig. 23; P1. I4, fig. 29; Pl. I9, fig. 57)

Phalaena didactylus Donovan, I8oo, Brit. Ins. 9: 65-66, pl. 3 I 8.

Alucita heterodactyla Haworth, I8I I, Lep. Brit. 3: 479.

I $C$. vaptor and C. tamsi have less strongly curved aedeagus, also their male ninth sternum rounded at the end, not pointed. 
Pterophorus heterodactylus Samouelle, I8r9, Ent. Useful Comp.: 409.

Pterophorus didactylus Curtis, 1827, Brit. Ent. fol. I6r.

Pterophorus heterodactylus Stephens, 1829, Cat. Brit. Ins. 2: 23 I.

Pterophorus heterodactylus Rennie, I832, Consp. Butt. Moths: 231.

Pterophorus heterodactylus Stephens, I835, Ill. Brit. Ent. Haust. 4: 377.

Pterophorus heterodactylus Wood, I838, Index Ent.: 238, pl. 51, fig. I65I.

Pterophorus heterodactylus Westwood, 1845, Brit. Moths, 2: 262, pl. 124, fig. 15.

Pterophorus hievacii Stainton, 1849, Syst. Cat. Brit. Tin.: 32 (partim).

Pterophorus hievacii Stainton, I854, List Brit. Anim. 16: 175 (partim).

Pterophorus heterodactylus Westwood, 1854, Wood's Index Ent.: 238, pl. 51, fig. 165I.

Pterophorus hievacii Stainton, I859, Manual, 2: 44I (partim).

Pterophorus hievacii Greening, I867, Ent. Mo. Mag. 4: 16-17.

Pterophorus hievacii Greening, I867, Ibid. 4: 39-40.

Pterophorus hievacii Knaggs (vii.I867) Ent. Mon. Mag. 4: 40.

Oxyptilus britanniodactylus Gregson (v.1869). Proc. Northern Ent. Soc. (Manchester), meeting of 22.v.I869, 3-4. ${ }^{\mathrm{I}}$

Pterophorus hievacii Jordan (vi.r869) Ent. Mon. Mag. 6: I4-15.

Pterophorus teucrii (Greening), Jordan (vi.I869) Ibid. 6: I4-I5.

Oxyptilus britanniodactylus Gregson (viii.I869) Entomologist, 4: 305-306.

Oxyptilus teucrii Jordan (xi.I869) Ent. Mon. Mag. 6: I22.

Oxyptilus teucrii Jordan (xii.r869) Ibid. 6: I5I.

Oxyptilus teucrii (Greening) Jordan, Knaggs, I87o, Ent. Ann. 18\%0: I43.

Pterophorus brittaniodactylus [sic!], Morris, I870, Brit. Moths, 4: 296, pl. I32, fig. I2.

Pterophorus (Oxyptilus) teucrii Barrett and Buckley, I871, Ent. Mon. Mag. 8: 155-156.

Oxyptilus parvidactylus Hw., Rössler, I88I, Jahrb. Nassau Ver. Naturk. 33-34: 22 (partim).

Oxyptilus teucrii (Greening) Jordan, Frey, I886, Stettin. Ent. Ztg. 47: I8 (partim).

Oxyptilus teucrii Greening, Leech, 1886, Brit. Pyral.: $57-58$.

Pterophorus heterodactylus Haworth, Mason, I888, Ent. Mon. Mag. 25: 162.

Oxyptilus heterodactylus Hw., Barrett, I889, Ibid. 25: 43I (partim).

Oxyptilus heterodactyla Müller, Tutt, I89o, Ent. Rec. 1: 94.

Oxyptilus teucrii (Greening) Jordan, Hofmann, I896, Ber. Naturw. Ver. Regensburg, 5: I I6-II9, fig. I (partim).

Oxyptilus teucrii Fuchs, I897, Stettin. Ent. Ztg. 1897: 338.

Oxyptilus teucrii (Greening) Jordan, Reutti, Meess und Spuler, I898, Lep. Faun. Baden, I52 (partim).

Oxyptilus heterodactyla Haworth, Crombrugghe; I90o, Rev. Soc. Ent. Namur, 4: 47-48.

Oxyptilus heterodactyla Haworth, Crombrugghe, I901, Ann. Soc. Ent. Belg. 45: ro3.

Oxyptilus teucrii Jordan, Rebel, I901, Cat. Lep. Pal. 2: 71 (partim).

Oxyptilus teucrii Jordan, Crombrugghe, I906, Mem. Soc. Ent. Belg. 13: 50.

Capperia heterodactyla Müller, Tutt, 1907, Brit. Lep. 5: 47I-490 (partim).

Oxyptilus teucrii Jordan, Spuler, I910, Schmett. Eur. 2: 324-325 (partim).

Oxyptilus heterodactylus Vill., Meyrick, 1913, Lep. Cat. 17: 7 (partim).

Oxyptilus heterodactylus Vill., Meyrick, I928, Rev. Handb.: 450.

Oxyptilus teucrii Jordan, Hering, 1932, Tierwelt Mitteleur., Ergänzb. I: I65 (partim).

Capperia britanniodactylus Greg., Pierce and Metcalfe, I938, Genit. Brit. Pyral.: 46, pl. 25.

Oxyptilus britanniodactylus Gregson, Fletcher, 1938, Ent. Rec. 1938: 77-78.

Capperia britanniodactyla (Gregson), Adamczewski, 1938, Fragm. Faun. Mus. Zool. Polon. 3: $235^{-236 .}$

Oxyptilus heterodactylus Villers, Lhomme, 1939, Cat. Lep. France, 2: I79 (partim).

Capperia britanniodactyla (Gregson), Adamczewski, I939, Ann. Mus. Zool. Polon. 13: 26i-266.

The very complicated synonymy of this species was cleared up by Fletcher (I938)

I Fide Fletcher's footnote (1946, in litt.) it was published at end of May I869 before Jordan's note of vi.r 869. 
as follows: Our Teucrium-feeding Oxyptilus cannot be called heterodactylus Villers. De Villers, who described it as $P[$ halaena $] A[$ lucita $]$ heterodactyla, (I789, Linn. Ent. 2: 535, no. I093) was not the original describer but merely copied the description from Müller, who described as Phal[aena] Alucita heterodactyla (I764, Fauna Ins. Fridrichsdal: 59) a Plume from Denmark. I do not think that it is safe to apply the name heterodactyla Müller I764 to our Teucrium-feeder, as this Oxyptilus apparently does not occur in Denmark (it is not included in four Lists of Danish Species, the latest in I930). Müller's description is very vague, merely 'black with white spots' - and of the known Danish Plumes it seems to apply best to Pselnophorus brachydactylus Kollar. The name Alucita heterodactyla Hw., I8II, taken from Villers, for the English Teucrium-feeder, is a primary homonym of Alucita heterodactyla Müller, I764, and hence invalid, as are all subsequent citations of Haworth's name under Pterophorus, \&c. Later on, this species was mixed up by Stainton under the name hievacii Zeller, which of course has nothing to do with it. Later still, it was known as 'teucrii Greening' or 'teucrii Jordan', but neither Greening nor Jordan ever described it as teucrii, which would have been an appropriate name. ... I consider, therefore, that its proper name is britanniodactylus Gregson, I869 (= teucrii Knaggs, I870 ; see also Adamczewski, I939). For my part I must add that in the main flora of Denmark (Lange, I880) Teucrium scorodonia is not recorded, and britanniodactyla feeds exclusively on this plant. Even if this food-plant was overlooked in Denmark it certainly would be very rare there and, of course, not growing commonly in gardens. Müller, however, states that heterodactyla lives in horto just as brachydactylus, which feeds commonly on weeds (Lactuca, Lapsana) in gardens, as I have observed in England. Therefore, as Müller's description of the imago corresponds much better with the nearly black brachydactylus than the brown-britanniodactyla, I think we can safely refer the name heterodactyla Müller to Pselnophorus brachydactylus Kollar as the proper name for this species.

Examined material:

I. Six specimens labelled 'England' received from T. B. Fletcher's collection (genit. praep.: 0-Ox. 73, ㅇ-Ox. 77).

2. Male specimen from Baden, named in Hofmann collection (British Museum (N.H.), London) as Oxyptilus teucrii, Green. and labelled: 'Hartwald, Herms. 22.6.9I' (genit. praep.: 1947/I07).

3. Female specimen from the same series, labelled 'Hartw., Reutti'.

External appearance. Capperia britanniodactyla is the largest palaearctic species in its genus. The wing spread of the specimens from Baden is $18-20 \mathrm{~mm}$., from England 20-2I mm. Meyrick (I928) gives 20-23 mm. by mistake, having in his collection wrongly named specimens. The ground colour of the wings is dark chocolate-brown, the pattern pure white. It is one of the darkest coloured species of Capperia. The similarly dark C. fusca is much smaller (I4-I6 mm.). C. britanniodactyla, in form, pattern, and even colour, is very similar to some forms of celeusi, but it is larger and usually darker. The best features for distinguishing this species from celeusi and lorana, which are often confused with it, are those provided by the copulatory apparatus.

Male copulatory apparatus quite different from lorana but more similar to celeusi. 
Valva slightly arched, more or less of the same width at both ends, bluntly ended. The flap on the valva projecting towards its base is large, elongate, and bluntly rounded at the end. Aedeagus quite different from that of celeusi; it also is S-like curved and bilaterally symmetrical, but shorter, thicker, and more strongly curved. Female copulatory apparatus similar to celeusi. The margin of the plate at ostium bursae formed like a ' $U$ ' and turned with its rounded part to the front of the body. The outlet of the ostium bursae is into one of the arms of the ' $U$ ' and in celeusi it is between these arms. My slides agree with the figures of the genitalia given by Pierce and Metcalfe (I938).

The habits and early stages of britanniodactyla were discussed by Tutt (I907: 476490). I observed the species at Belmont Downs, Belmont, Surrey, in England. The habits of the larva agreed with the description of Gregson (viii.I869). After hibernation the larvae damaged the food-plant (Teucrium scorodonia) and caused its partial and gradual drooping. In the folds of the withered leaves the larvae were hidden during inclement weather or while moulting. The larvae always attacked the main stem of the plant, biting out a hole in one side of it, usually just below the uppermost circle of well-developed leaves. Consequently, all of the top part of the shoot, with the leaves and the terminal bud, withers and drops down. Sometimes the stem is completely cut and its top falls on the ground. A very good figure of a damaged plant was published by South (I88I-I889).

The imago appears at the same time as the central European trichodactyla, i.e. from the end of May until August. Tutt collected all references in the literature concerning the time of appearance of the imagines and early stages of britanniodactyla, but he gave no opinion about the number of its generations. According to him the imagines appear at various times, depending on the weather, from the end of May and through June, and also in July and August. Gregson observes (Ent. 4: 306) that the young larvae emerged from eggs laid in June, and very quickly grew during July of the same year. He also states that the young larvae leave the eggs in autumn. That gives evidence of two generations. I observed this species in 1947 when the spring was unusually late. On 3-7 June Robinia pseudoacacia was hardly flowering, i.e. 2-3 weeks later than usual. At this time I very carefully searched all plants of Teucrium scorodonia at Belmont Downs. In this locality britanniodactyla appears very locally, only in little shady places where Teucrium grows amongst bushes of Rosa and Crataegus. I did not find any traces of feeding in open sunny places or in completely shady spots. At this time all traces of feeding found there, i.e. bitten stems and perforated leaves, were already dried in spite of a delayed spring. I found no fresh traces indicating that larvae were still feeding, nor did I find any larvae. Only pupae were present, and they were attached to the main stem of plants near the places where the stems were damaged. All were orientated with the head downwards. The pupae on the green part of the stem below the damaged spot were green, while those above this spot, on the dried and darkened part of the plant, were dark, grey-brown in colour, and similar to their substratum. Imagines emerged from to to 20 June. Because trichodactyla, which is very similar in its habits and time of appearance, has two generations, I do not doubt that britanniodactyla behaves in the same manner. I am convinced of this from my own observations and from Gregson's data. Similarly, 
as was observed by Gregson in the case of britanniodactyla, the larvae of the second generation of some other species of Capperia grow very quickly and the imagines are already on the wing in July and August, even in cooler localities in mountains (see C. fusca).

Geographical distribution. Capperia britanniodactyla is recorded from several localities in England and once only from Ireland and Scotland (Tutt, I907). This last locality is probably incorrect. The data concerning the appearance of this species on the Continent seemed doubtful because of confusion with similar species in the literature. Some of these statements I am able to correct because britanniodactyla doubtless is a monophagous species. As food-plants for the continental specimens of this group, Teucrium scordonia, T. chamaedrys, T. scordium, T. botrys, Marrubium vulgare, and $M$. peregrinum have been recorded. To britanniodactyla one can refer only the data concerning specimens bred or captured on Tencrium scorodonia, as follows:

I. Rössler (I88I) mentioned dark coloured specimens larger than parvidactylus and similar to the figure of marginella given by Herrich-Schäffer, which were captured around Teucrium scorodonia in the neighbourhood of Dotzheim (Weisbaden).

2. Fuchs (I897) cited specimens of 'Oxyptilus teucrii' captured at Lennig and Heimbachthale (Rhineland) on Teucrium scorodonia.

3. Reutti, Meess, and Spuler (I898) record 'Oxyptilus teucrii (Greening) Jordan' from a few places in Schwarzwald (Baden) where it was collected on Teucrium scorodonia ; they mentioned too 'var. celeusi Schmid (Frey)' living on Teucrium chamaedrys.

4. Crombrugghe de Picquendaele (I900, I90I) records 'Oxyptilus heterodactyla Hw.' from Belgium (Forêt de Soigne) as the species common on Teucrium scorodonia. Also from Belgium (Forêt de Libin) it is cited by Tutt, I907.

I examined the genitalia of the specimens captured by Reutti in Baden (Hartwald) which are present in the Hofmann collection in the British Museum. These specimens are identical with English britanniodactyla. It seems certain that the other abovementioned continental specimens captured on Teucrium scorodonia also belong to britanniodactyla. The continental data concerning the specimens of teucrii or its so-called varieties celeusi and lorana, which were recorded from other plants like Teucrium chamaedrys and Marrubium vulgare, were, as I verified, not britanniodactyla but other species. Frey's data (I886) concerning the occurrence of hieracii in England on Teucrium scordium are, of course, erroneous because scordium was never recorded for English specimens of this group. Also Frey himself says that he did not know the relevant literature and cited only some information 'received from Regensburg'. Spuler's statement concerning Marrubium peregrinum as a food-plant in this group is also erroneous (see Capperia fusca forma marrubii). Hofmann's data (I896) on Teucrium botrys must be explained by further investigations; I could not find in the Hofmann collection the specimens bred on Teucrium botrys. Besides the data from Belgium and west Germany, the discussed species was recorded by Tutt (I907) from Spain (heterodactyla, Moncayo, July I903, leg. Chapman). This record should also be verified. 
As shown by the above survey, britanniodactyla is distributed in Europe along the middle and lower parts of the Rhine and its tributaries (Meuse) and this distribution extends northwards to the British Isles. In the Tertiary, when the British Isles were a part of the Continent, the river Thames was only a tributary of the Somme and Rhine (Le Danois, I938). The presence of britanniodactyla in England is a relic of its ancient continuous distribution in the basin of the Rhine. This distribution gives evidence that this species appeared very long before our era (see Section 7). Capperia britanniodactyla (and probably $C$. lorana also) appeared during the first half of the Tertiary, on the west European island (Tyrrhenis) as one of many other forms which constitute the so-called Atlantic or Iberian element in the European fauna. These forms originated from the tropical Tyrrhenis partially preserved in western Europe. The increasingly cooler climate at the end of the Fertiary, and particularly the glacial periods of the Pleistocene, destroyed much of the Atlantic fauna in Europe. The classification of britanniodactyla amongst the Atlantic relics makes the records of this species from Spain (Tutt, I907) and France (Lhomme, I939) more probable.

\title{
2. Capperia celeusi (Frey), I886
}

\author{
(P1. I0, fig. 9; P1. I2, fig. 22 ; Pi. I5, fig. 30)
}

Oxyptilus marginellus Z., Hofmann \& Herrich-Schäffer, 1855, Lep. Faun. Regensburg, Fortsetz. I48.

Oxyptilus marginellus Zell., Herrich-Schäffer, 1856, Syst. Schm. Eur. 5: 372-373 (partim).

Oxyptilus parvidactylus Hw., Rössler, I88I, Jb. Nassau Ver. Naturk. 33-34: 222 (partim).

Oxyptilus celeusi Schmid in Frey, I886, Stettin. Ent. Ztg. 47: I8.

Oxyptilus celeusi (Schmid) Frey, A. Schmid, 1887, Korresp. Bl. Naturw. Ver. Regensburg. 40: 200202.

Oxyptilus teucrii (Greening) Jordan, var. celeusi (Schmid) Frey, Hofmann, I896, Ber. Naturw. Ver. Regensburg. 5: II6-II9, figs. 2, 9ab (partim).

Oxyptilus teucrii var. celeusi (Schmid) Frey, Reutti, I898, Lep. Baden: Zweite Ausgabe, I52.

Oxyptilus teucrii (Greening) Jordan, Klemensiewicz, I899, Spraw. Kom. Fizyogr. 34: 201.

Oxyptilus teucrii Jordan var. celeusi Frey, Rebel, I901, Cat. Lep. Pal. 2: 71.

Capperia heterodactyla Müller var. celeusi Frey, Tutt, 1907, Brit. Lep. 5: 474-475.

Oxyptilus teucrii Jordan var. celeusi Frey, Spuler, I9Io, Schmett. Eur. 2: 325 (partim).

Oxyptilus teucrii Stange [sic!], Stöckl, I9I I, Kosmos, Lwów, 35: 220.

Oxyptilus heterodactylus Vill., Meyrick, I913, Lep. Cat. 17: 7 (partim).

Oxyptilus teucrii Jordan, Schille, I914, Kosmos, Lwów, 39: I8I-182.

Oxyptilus teucrii (Jord.) celeusi Frey, Rebel, I9I7, S.B. Akad. Wiss. Wien. 126: 800 (?).

Oxyptilus teucrii Jordan, var. celeusi Frey, Bauer, I9I7, Mitt. Ent. Ges. Halle: II.

Oxyptilus teucrii Jordan, Müller-Rutz, I927, Mitt. Schweiz. Ent. Ges. 13: 5I4.

Oxyptilus teucrii Jord., Skala, I929, Ent. Z. 43: I97.

Oxyptilus intercisus sp.n., Meyrick, I930, Exot. Microlep. 3: 565 .

Oxyptilus teucrii Jord. var. celeusi Frey, Rebel \& Zerny, 1934, Denkschr. Akad. Wiss. Wien, 103: I34 (?).

Oxyptilus tencrii J., celeusi Frey, Müller-Rutz, I932, Mitt. Schweiz. Ent. Ges. 15: 240.

Oxyptilus celeusi Frey, Hering, 1932, Tierwelt Mitteleur., Ergänzbd. I: 165.

Oxyptilus heterodactylus Villiers, var. celeusi Frey, Lhomme, 1939, Cat. Lep. France, 2: 179 (partim).

Capperia celeusi (Frey), Adamczewski, 1938, Fragm. Faun. Mus. Zool. Polon. 3: 237.

Capperia celeusi (Frey), Adamczewski, 1939, Ann. Mus. Zool. Polon. 13: 26r-266. 
Examined material of Capperia celeusi (Frey):

I. Type specimen of 'Oxyptilus intercisus, Meyrick' (Deutsches Entom. Institut, Berlin): 'Oesterr. Küstenland, .Fužine 7.6.19o6, legit M. Hilf.', 'Coll. O. Leonhard', 'Typus', 'Meyrick det. Oxyptilus intercisus Meyr.' (female).

2. Male specimen of 'Oxyptilus intercisus, Meyrick' from Meyrick Coll. (B.M., London): 'Fuzhine, Croatia, M.H., 5.06.', 'Meyrick Coll. B.M. I938-290', 'Oxyptilus intercisus, Meyr. 3/I, E. Meyrick det. in Meyrick Collection', 'I947/65' (genit. prep.).

3. Male specimen of 'Oxyptilus britanniodactylus f. celeusi' (T. B. Fletcher Coll.): 'Regensburg'.

4. Male specimen of 'Oxyptilus teucrii, Jordan' (J. Müller-Rutz Coll.): 'Engadin, Switzerland'.

5. Male specimen of 'Oxyptilus teucrii' (Państwowe Muzeum Zoologiczne, Warsaw): 'Austria'.

6. Male specimen of 'Oxyptilus kollari' from Italian Alps (Magyar Nemzeti Muzeum, Budapest): 'Gomagoi'.

7. Male and female specimens of 'Oxyptilus teucrii var. celeusi' (Coll. Jäckh): 'Kaltenberg, Thüringen'.

8. Male specimen of 'Oxyptilus' (Magyar Nemzeti Muzeum, Budapest): 'Budafok, Hungaria'.

9. Male specimen of 'Oxyptilus kollari' (Magyar Nemzeti Muzeum, Budapest): 'Hautes Pyrénées, Cauterets, Juillet I89o, T. Seebold, coll. Eppelsheim'.

Io. Male specimen of 'Oxyptilus parvidactylus' (Magyar Nemzeti Muzeum, Budapest): 'Deliblat, Uhryk G., Flammunda 26.6.1909', 'O. parvidactylus, det. Rebel'.

II. Male specimen of 'Oxyptilus teucrii' from South Poland (Coll. Klemensiewicz, Cracow): 'nr. 4594, dr. O. Hofmann det. teucrii, dr. H. Rebel det. leonuri'.

I2. Male specimen of 'Oxyptilus hoffmannseggi' from France? (Coll. Constant): without further data, name only.

I3. Male and female specimens of 'Oxyptilus teucrii Jordan' from South Poland (Coll. Stöckl, Lwów): 'Janów ad Lwów'.

I4. Series of males and females of-Capperia celeusi (Frey) taken in several localities in Dniestr valley in Podolia (south Poland, districts Zaleszczyki and Borszczów) on Teucrium chamaedrys, leg. S. Adamczewski, I934-I938 (Państwowe Muzeum Zoologiczne, Warsaw).

Besides the specimens enumerated above there were examined two specimens wrongly named and recorded as Oxyptilus teucrii Jordan. They are a male specimen from France (Alpes-Maritimes) recorded by A. Schmidt (Enc. End. B. Lepidoptera, 3: I3I, Paris, I928) and a male from Poland (Lwów) recorded by Romaniszyn (Pol. Pismo Ent. 8: 222, I929). The specimen from Poland was Oxyptilus parvidactylus Hw. (genitalia examined) and the specimen from France was an Oxyptilus very similar to parvidactylus Hw. and probably belonging to that species. However, it is not yet clear which species of this group appear in the Mediterranean area.

The first indication of the distinctness of the species living on Teucrium chamaedrys is in Rössler's work (I88I). ${ }^{\mathrm{I}}$ Rössler, discussing specimens living on Teucrium scorodonia in the Rhineland, suggested that it was distinct from parvidactylus and that it might be the same species as the English teucrii or the species distinguished by Schmid from Regensburg as feeding on Teucrium chamaedrys. As seen from Rössler's remarks, Capperia celeusi was already known in I88I or before, having been recognized as a distinct species by Schmid. But in the literature this name does not appear until I886

I Much earlier, in I864-1866, Rössler distinguished amongst Oxyptilus obscurus Z. the specimens from Lorch as different. Judging from Rössler's description, they probably were specimens of Capperia lorana (see Rössler, Jahrb. Nassau Ver. Naturk. 19-20: 263). 
when Frey refused to recognize it as a species, saying that celeusi and teucrii are only variations of hieracii. (Similarly, in I856, Frey united with parvidactylus the Swiss specimens of Capperia fusca, in spite of the fact that he well knew the differences in the life-histories of the two forms. This error of Frey resulted in many difficulties in the systematics of this group and the Swiss entomologists still are not able to give the correct names for these forms.) Frey (I886) gives a few particulars concerning celeusi, and according to the rules of nomenclature we must consider Frey's criticism of the distinctness of celeusi as a valid description; therefore the name celeusi bears Frey's name as describer, because it is really a distinct species. Unfortunately, Schmid's description of celeusi was published later (I887), after Frey's remarks. Frey did not know this group well, but it is so difficult that even Zeller, the best microlepidopterologist of the period, made some mistakes in it. Zeller named the specimens from Regensburg, doubtless belonging to celeusi (which was not known then), as marginella Herrich-Schäffer (I856). Schmid published his description of celeusi while he was discussing the problem with Frey (I887). He gave some morphological and ecological features distinguishing this species. Unfortunately the authority of Frey prevailed in the opinion of entomologists and even in the last catalogue of Rebel (I9OI) celeusi still appears as a variety only. This was mainly due to Hofmann, who published (I896) his erroneous observations about the identity of the genitalia of celeusi, teucrii, and lorana. (Similarly, in I898, Hofmann considered identical the genitalia of trichodactyla ('leonuri') and fusca, thus increasing the chaos introduced by Frey into the systematics of Plume-moths.) Oxyptilus intercisus Meyrick, as has been proved by examination of the genitalia of Meyrick's types, was simply Capperia celeusi. Meyrick created intercisus (published in Exotic Microlepidoptera as from Croatia!) as a new species because he did not know the European Microlepidoptera well. In his collection there were no specimens of celeusi and the nearest species heterodactyla (= britanniodactyla D. \& S.) was quite wrongly determined. Under the name heterodactyla there was in the Meyrick collection a series of Swiss specimens near to distans Zeller which at present I am not able to name (see genus Crombrugghia Tutt). Other species of this group were also wrongly named in Meyrick's collection; for example, under the name pilosellae there is only one specimen of that species, labelled 'Germany', but there is, also under pilosellae, a series of chrysodactyla D. \& S. (= hieracii $Z$.). Excepting the specimens of intercisus, there are no specimens of celeusi, and similarly many other European species are lacking in Meyrick's collection. Looking through the Meyrick collection, it is difficult to understand how it was possible to describe new palearctic species without comparative material of so many species and with so many specimens of other species wrongly named.

Capperia celeusi Frey is a medium-sized species in its genus. The wing spread is I6-20 $\mathrm{mm}$. It varies in size even in the same generation. Specimens captured in the same locality and at the same time and perhaps belonging to the same population vary much in size, as I observed in the valley of Dniestr in June. But on the south slopes of the Dniestr valley they occur in very dry and burnt places near other areas that are covered with fresh vegetation, and this fact may be connected with the differences in the size of imagines and may be due to the different quality of food. In the colour of celeusi there is also some variability. Using the terminology of Tutt 
(I907) one can distinguish amongst celeusi three types of colour: coffee-brown, yellow-brown, and greyish-brown. The darkest coloured (coffee-brown) specimens are those from Croatia (intercisus). The specimens from Regensburg (Bavaria) and from Lwów (coll. Stöckl.) are brighter (yellow-brown). (The brown-coloured specimens of Hofmann from Urach belong to another species-see Capperia fusca forma marrubii.) From other localities the specimens are more or less brown with a grey tint. Similar variation in colour occurs in Oxyptilus parvidactylus Hw., and consequently the external appearance of greyish-brown specimens of the two species is sometimes extremely similar. (In the Mediterranean area there exist also some species of Capperia very similar to celeusi.) Amongst the greyish-brown specimens of celeusi there are also some differences. The greyish specimens from the Dniestr valley (Podolia) have their white pattern weakly developed, but the greyish specimens from Thuringia are vividly marked with white and all the white bands on the wings and white spots in the cilia are larger than in specimens from Podolia. Some specimens from Thuringia have, moreover, a white spot in the cilia of the hind margin of the second feather of secondaries (which is present also in $C$. washbourni). The tuft of scales on the hind wing varies also with the degree of darkness of the specimen and the quantity of white scales in it, but these are very small differences. It is necessary to collect much material of bred series from several localities in order to study the variability of $C$. celeusi.

The copulatory apparatus. Valva slightly arched, strongly sclerotized, and of nearly the same width throughout its length. The flap on the valva projecting towards its base is not very long and is bluntly rounded at the end. The top of the valva more or less obliquely cut off and in the specimens from Podolia, Bavaria, and Switzerland more pointed, but in those from Thuringia and Hungary it is more bluntly ended (may be the results of mounting in Canada balsam and not real differences). The ninth tergum is pointed in specimens from Podolia and Hungary and has a small incision on the top in the specimens from Germany. The specimen from Lwów is intermediate, having scarcely any incision on the top of the ninth tergum, but in its colour this specimen is most similar to the specimen from Bavaria. Aedeagus strongly curved like an ' $S$ ', without asymmetric appendages and very constant in form. The ninth sternum bifurcate at the end in the form of two pointed flaps reaching the top of the valvae. The female copulatory apparatus with a very characteristic plate at the ostium bursae. The form of this plate is like a ' $U$ ' or an irregular triangle, of which the base is situated at the ostium and the elongated top is asymmetrically curved on the side. The ostium bursae lies between the arms of the ' $U$ '.

The distinctness of celeusi from britanniodactyla is confirmed by the difference in appearance of their larvae. Hofmann gives a description of the larva of celeusi (I896) and cites also a different description of the larva of britanniodactyla by Leech (I886).

The life-history of celeusi needs careful study because in the published literature there are several errors. Certain allied species have been confused and for this group the following food-plants are recorded from England, France, Belgium, Poland, and Germany: Teucrium chamaedrys (Rössler, I88I ; Frey, I886; Schmid, I887; 
Hofmann, I896; Adamczewski, I938; Lhomme, I939), Teucrium scordium ${ }^{1}$ (Frey, I886), Teucrium scorodonia (Rössler, I88I ; Fuchs, I897 ; Reutti, Meess, and Spuler, I898; Crombrugghe, I900, I90I), Teucrium botrys (Hofmann, I896; Lhomme, I939), Marrubium vulgare ${ }^{2}$ (Rössler, I88I ; Steudel and Hofmann, I882; Hofmann, I896; Lhomme, I939), Marrubium peregrinum ${ }^{2}$ (Spuler, I9I0; Lhomme, I939). Further, Tutt (I907) recorded Thymus serpyllus amongst the food-plants of parvidactylus. With parvidactylus, which feeds on Compositae, species of the genus Capperia, which feed monophagously on various Labiatae, have very often been mixed. Thymus belongs also to Labiatae and it would be very interesting to know to what genus the specimens from Thymus mentioned by Tutt belong. Could they be a new Capperia? Because of the strict monophagy of the species of Capperia it is quite certain that the insects breeding on the above-mentioned plants belong to several different species, some of which may not yet be described. Examination of Reutti's specimens showed that the continental insects feeding on Teucrium scorodonia are C. britanniodactyla. Hofmann's specimens from Marrubium vulgare, also examined, belong to C. fusca forma marrubii and are quite different from celeusi and close to fusca. The specimens recorded from Teucrium scordium and Marrubium peregrinum never existed on these plants, the names of which were evidently changed by Frey and Spuler. The specimens bred from Teucrium chamaedrys, which I examined, were all $C$. celeusi. The only specimens I could not find were those from Teucrium botrys recorded by Hofmann, but it will be better to postpone further discussion of them until they can be examined; they might be $C$. lorana.

So far as is known Capperia celeusi is a monophagous insect breeding on Teucrium chamaedrys. It appears in two generations. The imagines of the first generation fly from the end of May till the middle of June (Adamczewski, I938). The summer generation is on the wing through the second half of July. Late specimens appear in the beginning of August (Hofmann, I896).

Geographical distribution. Capperia celeusi has been recorded under various names from Spain, France, Belgium, Switzerland, Saxony, Thuringia, Bavaria, Baden, Württemberg, Rhineland, Croatia, Slovenia, Montenegro, Albania, Macedonia, Hungary, Romania, and Poland. Most of these are physiographic data without any supplementary particulars, and without the examination of specimens they cannot be verified. These records are useless, especially Rebel's from the Balkan States. Müller-Rutz (I938, in litteris) gives the following localities for celeusi in Switzerland (under the name 'Oxyptilus teucrii Jordan'): Brig, Kalpetran, Mendrizio, Ardez, Engadin. I verified only his record from Engadin, which was definitely celeusi. Judging from the material which I revised and verified myself, the distribution of Capperia celeusi is as follows: Bavaria (Regensburg), Thuringia (Kaltenberg), Austria (no further data), Switzerland (Engadin), Italy (Gomagoi in Alps), France (HautesPyrénées), Croatia (Fužine), Serbia (Deliblat), Hungary (Budafok), Poland (Lwów and Dniestr Valley). Because some of the records in the literature appear erroneous (Schmidt, I928; Romaniszyn, I929), I cannot accept other published localities.

I Vide Capperia britanniodactyla (Gregson).

2 Vide Capperia fusca (Hofmann) forma nova marrubii. 
3. Capperia washbourni sp.n.

(P1. I0, fig. 8; Pl. I2, fig. I9; Pl. I5, fig. 33; Pl. I7, fig. 4I)

Examined material:

I. Holotype. Male specimen from Syria (British Museum, London): 'Shar Deresy, Syria I 893 , Leech (Nat. Coll.) 61527'; 'Walsingham Collection I9ro-427'; 'Compared and agreeing with one named by Rag. Oxypt. marginellus Z. ? but larger'; 'Oxyptilus marginellus Z. ?'; 'No. praep.: Ox. 88' (genit. praep.).

2. Allotype. Female specimen from Asia Minor (Magyar Nemzeti Muzeum Collection, Budapest): 'Asia min., Amasia i888, Korb, kollari, coll. Eppelsheim'; 'No. praep. Ox. Io7' (genit. praep.).

3. Paratype. Female specimen from Palestine (Deutsches Kolon. Museum Collection, Bremen): 'Jericho (Palästina), Lichtfang 3o.iv.1930, leg. H. G. Amsel' ; 'O. marginellus' (Rebel det.) ; 'No. praep. Ox. IoI' (genit. praep.).

Capperia washbourni is of medium size for its genus. The wing spread of the male is $\mathrm{I} 8 \mathrm{~mm}$., the female $\mathrm{I}_{5} \mathrm{~mm}$. (Palestine) and $\mathrm{I} 7 \mathrm{~mm}$. (Asia Minor). The ground colour of the wings is dark, chocolate-brown in the specimens from Syria and Asia Minor, a little lighter in the specimen from Palestine. The bands on the fore wings vivid white and very distinct. The fore margin of the fore wings on its lower side pure white. On the hind margin of the second feather of the hind wings, in the middle, the dark cilia are interrupted by white hairs. (A similar white mark, but less distinct, is present in some specimens of celeusi from Thuringia.) From celeusi it is distinguished by a different tuft of scales on the third feather of the hind wings. In this tuft, in washbourni, the dark scales on the fore margin of the feather do not reach its end as in celeusi and other allied species. The end part of the third feather in washbourni is completely white on its fore margin. ${ }^{\mathrm{I}}$

Male copulatory apparatus similar to celeusi. It differs from celeusi in the form of the valva, which in washbourni is nearly twice as wide in the distal half as in the basal. The ninth tergum pointed, without an incision on the top. The aedeagus bilaterally symmetrical, similar to that of celeusi but a little thicker and a little less strongly curved. The ninth sternum large, ending with two pointed flaps which are a little shorter than in celeusi. This sternum is a little more convex ventrally than in celeusi. The female copulatory apparatus of the same kind as in celeusi and britanniodactyla, i.e. with the plate like a ' $U$ ' near ostium bursae. The asymmetrical top part of this plate is longer and narrower in washbourni than in related species.

The early stages and the food-plant are unknown.

Geographical distribution. Asia Minor, Syria, Palestine.

\section{Capperia ningoris (Walsingham), I88o}

Oxyptilus ningoris sp.n., Walsingham, I88o, Pter. Calif. Oreg.: 26, pl. 2, fig. 6.

Pterophorus ningoris Wlsm., Fernald, I898, Pter. N. Amer.: I9-20, pl. 6, figs. I-3.

Oxyptilus ningoris Walsingham, Meyrick, I9ro, Gen. Ins. 100: 7 .

Oxyptilus ningoris Walsingham, Barnes \& Lindsey, I92 I, Contr. Nat. Hist. Lep. Amer. 4: 305307, pl. 4I, fig. 7, pl. 49, fig. 6 .

I have confined my examination of this species to the figures of the copulatory apparatus given by Fernald (I898) and Barnes and Lindsey (I92I), and the figures of

I The end part on the fore margin in washbourni is white, but never on the very top as in Oxyptilus hoffmannseggi. 
imagines given by Walsingham (I880) and Barnes and Lindsey (I92I). These figures and descriptions agree with the external appearance of the Walsingham specimens in the British Museum.

The species is rather similar to britanniodactyla in its size and colour. The wing spread is $I 8-20 \mathrm{~mm}$. The colour is dark-brown but with little greyish tint, so that ningoris is duller than britanniodactyla.

Male copulatory apparatus, as figured by the above-mentioned authors, is quite different from that of the nearest palaearctic species, i.e. britanniodactyla and celeusi. Aedeagus also strongly curved like an ' $S$ ', but ending without bifurcation. Valva much narrower in the basal half than in the end half, similar to that of washbourni. Female copulatory apparatus unknown.

Early stages unknown. Walsingham remarked that he probably collected this species on Teucrium sp., but he was not certain.

Geographical distribution. A North American species known from California. The record of Blackmore (I922) from British Columbia was probably erroneous because McDunnough (I926) does not cite this species from Canada.

\section{Capperia evansi (McDunnough), I923}

Pterophorus evansi sp.n., McDunnough, 1923, Canad. Ent. 54: 85-86.

Pterophorus evansi McD., McDunnough, 1926, Rep. Ent. Soc. Ont. 25: 50.

Pterophorus evansi McD., McDunnough, I927, Trans. Roy. Soc. Can., sect. V, 1927: I76, pl. I, fig. 3 .

Pterophorus evansi McD., McDunnough, I935, Canad. Ent. 5\%: 71-73.

I have had no opportunity for examining this species, but the descriptions and figure given by McDunnough have made it possible to put evansi in its proper systematic position. McDunnough described evansi as similar in size and colour to tenuidactyla Fitch. It is a small species (wing spread I4 mm.), dark brown, but the brown is somewhat duller than in tenuidactyla. The features cited by McDunnough as separating evansi from tenuidactyla (colour, structure of palpi and of legs, and form of the second lobe of fore wing) are generic features distinguishing the genera Geina and Capperia and not especially the two species.

The male copulatory apparatus (McDunnough, I927, fig. 3) differs from that of any other species of Capperia in the form of its aedeagus. The aedeagus is curved like an ' $S$ ' but very thin and very strongly broken in bends. The valva, ninth tergum, and sternum in McDunnough's figure seem to be similar to britanniodactyla or celeusi. At the end of the valva a process similar to that of trichodactyla is present.

The morphology and habits of the early stages are described by McDunnough (I935). C. evansi appears in two generations. The imagines appear at the beginning of June, and again from the middle of July till the beginning of August. McDunnough gives also some ecological data.

The larvae feed on Scutellaria sp. and they have the same habit as britanniodactyla in damaging the main stem of the plant and making it droop. They are hidden amongst withered leaves.

The species is known from Canada only. 
6. Capperia trichodactyla (Denis et Schiffermüller), I775

(P1. I0, fig. 7 ; P1. I3, fig. 25; Pl. I4, fig. 26)

Alucita trichodactyla, Denis \& Schiffermüller, I775, Schmett. Wien, I45: (3).

Alucita trichodactyla, Denis \& Schiffermüller, I776, Ibid. I45: (3).

Phalaena Alucita trichodactyla, Hübner, I790, Beitr. zur Gesch. Schmett. 2 (Nachtr): Io9-I Io.

Alucita trichodactyla, Illiger, I801, Syst. Verz. Schmett. Wien. Gegend. 2: 130.

Alucita trichodactyla, Hübner, I802-1805, Gesch. Eur. Schmett.: pl. 498, figs. 2-2ab. ${ }^{\mathrm{I}}$

Alucita trichodactyla, Hübner, I805-1813, Samml. Eur. Schmett.: pl. 4, fig. I8. ${ }^{1}$

Amplyptilia trichodactyla, didactyla, chrysodactyla Schiff., Hübner, I826, Verz. Bek. Schmett.:

430, no. 4I84 (partim).

Alucita didactyla Treitschke, Ochsenheimer, I833, Schmett. Eur. 9: 237-238 (partim).

Pterophorus didactylus Linn., Zeller, I839, Isis, 32: 275 (partim).

Pterophorus obscurus var. $b=$ Phalaena trichodactyla mus. Schifferm., Zeller, I84I, Ibid. 34:

793-794.

Alucita trichodactyla S.V., Zeller, I84I, Ibid. 34: 882.

Oxyptilus leonuri sp.n., Stange, I882, Stettin. Ent. Ztg. 43: 514-5I6.

Oxyptilus leonuri Stange, I886, Ibid. 4\%: 285-286.

Oxyptilus leonuri Stange, Hofmann, I896, Ber. Naturw. Ver. Regensburg. 5: II9-I2I.

Oxyptilus leonuri Stange, Hedemann, I897, Verh. zool. bot. Ges. Wien, 1897: 2.

Oxyptilus leonuri Stange, Hofmann, 1898, Ill. Zeit. Ent. 3: 308.

Oxyptilus leonuri Stange, Klemensiewicz, 1898, Spraw. Kom. Fizyogr. 33: 189.

Oxyptilus leonuri Stange, Klemensiewicz, I899, Ibid. 34: 201.

Oxyptilus leonuri Stange, Klemensiewicz, I901, Ibid. 35: 99-1oo.

Oxyptilus leonuri Stange, Rebel, I90I, Cat. Lep. Pal. 2: 7I (partim).

Capperia leonuri Stange, Tutt, I907, Brit. Lep. 5: 4I I.

Oxyptilus leonúuri [sic!] Stange, Spuler, I910, Schmett. Eur. 2: 324.

Oxyptilus leonuri Stange, Meyrick, I910, Gen. Ins. 100: 7 .

Oxyptilus leonuri Stange, Rebel, I9I I, Ann. Naturh. Hofmus. Wien, 25: 397 (?).2

Oxyptilus leonuri Stange, Meyrick, I9I3, Lep. Cat. 1\%: 7 (partim).

Oxyptilus leonuri Stange, Schille, I9I4, Kosmos, Lwów, 39: I8I.

Oxyptilus leonuri Stange, Rebel \& Zerny, I93I, Denkschr. Akad. Wiss. Wien, 103: I34 (?). ${ }^{2}$

Oxyptilus leonuri Stange, Hellen, I93I, Notul. Ent. 11: 57 (?). ${ }^{2}$

Oxyptilus affinis sp.n., Müller-Rutz, I933, Mitt. Schweiz. Ent. Ges. 15: 553.

Oxyptilus affinis sp.n., Müller-Rutz, I934, Ibid. 16: I18, pl. I, fig. I.

Oxyptilus leonuri Stange, Toll, 1934, Bull. Ent. Pologne. 12: 35 (?). ${ }^{2}$

Oxyptilus leonuri Stange, Toll, I937, Ibid. 14-15: 239 (?). ${ }^{2}$

Oxyptilus leonuri Stange, Osthelder, I937, Iris, 51: 106 (?). ${ }^{2}$

Capperia leonuri Stange, Adamczewski, I939, Ann. Mus. Zool. Polon. 13: 26r.

In the group discussed below Denis and Schiffermüller distinguished three species, didactyla L., trichodactyla sp.n., and chrysodactyla sp.n., which are at present reckoned in three genera, i.e. Geina, Capperia, and Oxyptilus. However, Hübner synonymized all these species under the name 'trichodactyla Schiff.' and put them under the same number (Verz. Bek. Schmett., I826, no. 4I84). Hübner's use of the name trichodactyla is explained by him in his Beiträge as follows: 'Die andere nährt sich von den welken Blättern des Herzgespanns, ebenfalls im Lenze; ihren Sitz hat sie

I The dates of Hübner's publications fide Hemming, 1937.

2 The data bearing the sign '?' need verification; Rebel's determinations are particularly unreliable in this group; I have seen the specimen of celeusi from Poland, named by Rebel as leonuri; Hellen's record from Finland, an unusual far northern locality, needs verification also; the data of Toll (I934, 1937) and of Osthelder (1937) as concerning the imagines captured in lowland places, at the end of June and beginning of July, are probably erroneous.

ENTOM. I, 5 . 
auf der untern Flache. Die welke Blätter erhält sie dadurch, weil sie den Stengel des Blattes zuvor fast abbeist, ehe sie etwas davon geniest. Daraus kommt die $\mathrm{Ph}$. Aluc. Trichodactyla des Syst. Verz.' (Beiträge zur Gesch. Schmett. 2, Nachtrag: IgoII0, U, I790). Then Illiger, in his new edition of Wiener Verzeichniss, combines the short description of Denis and Schiffermüller with the ecological data cited by Hübner and gives the following description: 'Braunes, weissgestrichtes Geistchen, A. trichodactyla. Raupe lebt von welken Blättern des Herzgespanns' (Syst. Verz.

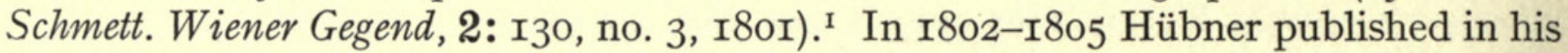
Geschichte coloured figures of the larva and pupa of trichodactyla and also its foodplant, Leonurus, illustrating the very characteristic damage. But the coloured drawings of imagines of trichodactyla published by Hübner in his Sammlung (I805-I8I3, figs. 9 and 18 ), without doubt belong to two species. Fig. I $8^{2}$ is trichodactyla, but fig. 9 (published also as trichodactyla) represents another species, namely, chrysodactyla. ${ }^{3}$ Both figures are poor and inexact, and for that reason they were misunderstood and synonymized by later entomologists. Before Zeller revised this group the species belonging here were too difficult to separate, not only for Hübner himself, but also for other contemporary entomologists after Schiffermüller. Fabricius, who had seen Schiffermüller's collection, ${ }^{4}$ the so-called Wiener collection, neglected the two newly described species trichodactyla and chrysodactyla (probably as forms not deserving names as separate species) and mentioned in his works only one species of this group, i.e. didactyla (I787, Mantissa, p. 258; I794, Ent. Syst. 3: pt. 2, p. 346). Hübner also had the opportunity to study Schiffermüller's collection, and the drawings published by Hübner correspond to Schiffermüller's specimens. Charpentier, who examined also Schiffermüller collection, published in I82I his remarks on Schiffermüller's specimens and Hübner's corresponding drawings (Die Zinsler, Wickler, \&c.: I74 et seq.). Charpentier, like Fabricius and Hübner, had some difficulty in distinguishing the three species. He stated that didactyla ${ }^{5}$ in the Wiener collection agreed perfectly with chrysodactyla, and that trichodactyla also appeared to agree with chrysodactyla, and that ' this species '6 was figured by Hübner (figs. 9 and I8) as trichodactyla. Hübner's incorrect synonymy was followed by others. However, Hübner did not properly use the earlier name when he synonymized trichodactyla, and for this reason he was corrected by Treitschke (I833), who put all the synonymy under the oldest name, didactyla L. In Treitschke's opinion the differences between figs. 9 and $\mathrm{I} 8$ of Hübner represented sexual dimorphism in didactyla. In Treitschke's description of didactyla are some ecological data and also the description of the pupa and the larva feeding on Leonurus. These data, of course, refer to Capperia trichodactyla Denis et Schiffermüller and not to Geina didactyla Linnaeus. Zeller tried to disentangle the synonymic difficulties in this group, but unfortunately did not know the species living on Leo-

I Hagen (Bibl. Ent. r862: 399) cited the date 'r8oo'!

2 Erroneously considered later by authors as didactyla L., which probably did not exist in the Weiner and Hübner collections.

3 Chrysodactyla of Denis and Schiffermüller = hievacii Zeller.

4 Wiener Verzeichniss was published by Denis and Schiffermüller, but the Wiener Sammlung belonged to Schiffermüller only.

5 It seems quite certain that didactyla from the Wiener collection was not the Linnean didactyla. Most probably it was an Oxyptilus species later described by Zeller (ericetorum or pilosellae).

6 Charpentier considered those three species as forms of the same species. 
nurus. Because of this his efforts were not successful. Zeller knew didactyla only from the very short and unsatisfactory description of Linnaeus and he was not sure if the synonymic interpretation of Treitschke was correct or not. Zeller used the name 'trichodactyla Hb.' for his own specimens of Geina didactyla Linnaeus, the life-history of which was unknown to him. His determination was based on the plates of Hübner's Sammlung because fig. I8 is really quite similar to the Linnean didactyla. Zeller, by his conscientiousness, perpetuated Hübner's mistake, although he was unaware of it, and used for Geina didactyla Linnaeus the name applicable to the Leonurus-feeder. Herrich-Schäffer followed in Zeller's footsteps, giving in his work a very accurate coloured figure of Geina didactyla Linnaeus, but under the name trichodactyla. Obviously, with such an interpretation, this name could not be kept very long. Wocke, in his Catalogue (I87I), corrected the mistakes of Zeller and Herrich-Schäffer as Treitschke, in I833, similarly corrected Hübner's synonymy. In this way the central European specimens of Geina didactyla Linnaeus regained their proper Linnean name, but at the same time two valid species were overlooked, namely, trichodactyla Denis et Schiffermüller and chrysodactyla Denis et Schiffermüller. One of them, chrysodactyla, was not only overlooked but was completely forgotten. The other one, trichodactyla, following Hübner, Treitschke, and others, has been incorrectly considered a synonym of didactyla Linnaeus until the present time (Rebel, I90I; Meyrick, I9I3). One can also find some support in the publications of Zeller for the restitution of the name trichodactyla for the species feeding on Leonurus. In his description of Pterophorus obscurus Z., Zeller (I84I) distinguished a 'var. b' and under it he put Schiffermüller's specimens named as trichodactyla. On p. 793, under the sub-title 'B. (Io) 3. Pteroph. obscurus Zell.' there occurs after the description of species: 'Phalaena trichodactyla mus. Schifferm. Var. b. digiti tertii medio albido', and farther on, p. 794: 'Das dritte Viertel dieser Feder ist öfters weisslich (var. b)', and farther, on the same page: 'Meine Exemplare habe ich bei Glogau gefangen oder aus der Puppe erhalten; ein oesterreichisches Exemplar befindet sich in Herrn Metzners Sammlung aus welcher es mir als neue Art zu Ansicht mitgetheilt wurde; ein anderes erhielt ich von Hrn Fischer v. Roeslerstamm aus der Wiener Gegend als Phal. trichodactyla der Schiffermuellerschen Sammlung.' On pp. 832-833, under the sub-title 'B. (I2) 5. Pteroph. trichodactylus Hüb.', Zeller discussed his own specimens which he considered as identical with 'Hübn. Aluc. fig. I8 (fem.) trichodactyla'. This was a mistake, and as Zeller's description shows, it was Geina didactyla Linnaeus in his collection, not trichodactyla. On pp. 880-883 Zeller discussed the Plume-moths of the Wiener Verzeichniss. There on p. 88I under the sub-title '2-3. Al. chrysodactyla S. 320 ' occurs the following:

'Ein Exemplar aus der Wiener Gegend das ich vergleiche und das genau mit den Exemplaren der Schiffermueller'schen Sammlung übereinstimmen soll, ist ein mittelmässig grosser Ptev. hievacii. Wie könnten aber, frage ich, die Verfasser des Verzeichnisses aus einer so wenig veranderlichen Art zwey machen? Wie könnten sie an der zweyten "'goldglänzende Querstriche"' sehen ? Was gar kein Druckfehler seyn kann, da der name chrysodactyla eben dahin deutet. Unserer Art könnte man höchstens silberglanzende Querlinien beylegen. Dass ich mir in meiner Arbeit des Namens chrysodactyla enthalte, versteht sich von selbst.'

The above commentary, in spite of the intention of Zeller, explains what is meant 
by chrysodactyla, the name overlooked and forgotten by later systematists. It is simply a synonym of Oxyptilus hieracii Zeller. Further, in the same publication, on p. 882, under the sub-title ' 3 . Al. trichodactyla' we find:

'F. v. Roeslerstamm's Worte in Manuscript sind: “Das Exemplar der Sammlung besteht nur noch aus einem Vorder- und einem Hinterfluegel, welche an einem Stueckchen Leib haengen. Es ist ausser der Kleinheit, selbst fuer das bewaffnete Auge in nichts von den beyden vorigen (didactyla, chrysodactyla) verschieden, und sind daher alle 3 als eine Art so lange anzunehmen, bis wir sichere Unterscheidungszeichen entweder im Schmetterlinge oder in der Raupe aufgefunden haben".-Ein als "genau Trichodactyla mus. Schffm." bezeichnetes Exemplar ist mein Pteroph. obscurus. Sollten die Verfasser des Verzeichnisses, ohne durch die frueheren Staende aufmerksam gemacht zu sehen, eine so schwer zu unterscheidende Art wirklich von Pter. hievacii unterschieden haben? Kaum glaublich! Ich lasse daher den Namen Trichodactylus der Huebner'schen Al. trichodactyla fig. I8, und schaffe dieser Schiffermueller'schen einen neuen Pt. obscurus.'

On p. 885 Zeller discussed Hübner's figures of Alucita trichodactyla. In Zeller's opinion fig. 9 is his Pterophorus hievacii and fig. I8 his Pterophorus trichodactylus. But Zeller's interpretation of fig. I8 is not correct because this figure represents the true trichodactyla (not known to Zeller) and not Geina didactyla Linnaeus (= trichodactyla Zeller). Clearly Zeller considered that his 'obscurus var. $b$ ' was the same form that Denis and Schiffermüller described as trichodactyla. Of course the characters of 'obscurus var. $b$ ' agree with the characters of the Leonurus-feeder. They are the generally dark colour and the white middle part of the third segment of secondaries. The small size of the specimen from the Wiener collection shows that it was a specimen of the summer generation of Capperia trichodactyla. The second generation, feeding on flower-shoots of Leonurus, gives imagines smaller than imagines of the spring generation living on the lower leaves of the plant. Most of the specimens of the summer generation I bred in the neighbourhood of Warsaw were of the size of parvidactylus (= obscurus Zeller). Besides, trichodactyla and didactyla have the middle part of the third feather white, a character possessed also by the south European forms not appearing in Austria: i.e. Oxyptilus hoffmannseggi Möschler and southern specimens of forma marubii of Capperia fusca Hofmann. This form is much brighter coloured and has nothing to do with the dark specimens discussed by Zeller. It is known to me only from two females from Yugoslavia and Greece. Possibly it is a distinct species or perhaps the form of Capperia fusca Hofmann that occurs also in Austria. But even in this case the specimen from the Wiener collection could not be fusca because the specimens of fusca from the mountainous environs of the Alps and Carpathians always have the third feather of secondaries completely dark, not white in the middle. Thus Zeller's remarks provide additional evidence that trichodactyla Denis et Schiffermüller is nothing other than the Leonurus-feeder the early stages of which were figured by Hübner (figs. $2 a, 2 b$ ) and for which some ecological data and notes were given by Treitschke (I833) under the incorrect name didactyla. In this paper I correct the synonymic errors of Hübner and later systematists and restore the names of Denis and Schiffermüller as follows:
I. Capperia trichodactyla Denis et Schiffermüller (=leonuri Stange, = affinis Müller-Rutz).
2. Oxyptilus chrysodactylus (Denis et Schiffermüller) (= hieracii Zeller). 
3. 'didactyla Denis et Schiffermüller' is not the same as Geina didactyla Linnaeus, but a species similar to chrysodactylus, probably ericetorum or pilosellae, but this name is preoccupied by Linnaeus. From the statement of Laspeyres (I805) and of Charpentier (I92I) it is apparent that the genuine didactyla of Linnaeus did not exist in Schiffermüller's collection. However, this species was known in the neighbourhood of Wien before the publication of Denis and Schiffermüller, as seen from the coloured figure of the unnamed Pterophorus published by Schaeffer in I766 (Icones Ins. Ratisb.: pl. 93, fig. 7, I766).

Oxyptilus affinis Müller-Rutz, described from Switzerland, is a synonym of Capperia trichodactyla Denis et Schiffermüller. Through the kindness of Mr. Müller-Rutz I received for examination two co-types of affinis ( $\hat{0}$ and 9 ) labelled as follows: ' $\widehat{o}$, affinis, Remüs, I7.vi.3I, G.P.K. I9' and 'o affinis, Remüs, 2.vii.3I'. The preparation of the genitalia (GP. = Genitalpräparate) used in the description of the species (I934) was made from this male specimen. Mr. Müller-Rutz sent me also the drawings of the male copulatory apparatus with the following labels: 'Oxyptilus affinis M.R., Remüs, Unt. Engadin, I7.vi.3I (II50 m.)' and 'Oxyptilus teucrii Jordan, Ardez, Unt. Engadin 28.vi.2I (I400 m.)'. These drawings show without doubt that affinis Müller-Rutz equals trichodactyla Denis et Schiffermüller and teucrii Müller-Rutz equals celeusi Frey. I made a preparation from the other co-type of affinis (female) and the examination showed it was also trichodactyla. In external appearance the co-types of affinis do not differ from specimens from Poland (Lwów, leg. Klemensiewicz; Warszawa, leg. Adamczewski).

External appearance. Capperia trichodactyla Denis et Schiffermüller in the spring generation is larger; wing spread $\mathrm{I} 7-20 \mathrm{~mm}$. The co-types of affinis (also first generation, but appearing in mountains a few days later than in thelowland) were $\mathrm{I} 8 \mathrm{~mm}$. The summer generation is smaller, alar expanse $\mathrm{I} 5-\mathrm{I} 8 \mathrm{~mm}$. The ground colour of wings is dark brown with very characteristic olive-coloured hue. This character permits easy separation from allied species. The light pattern on the wings is not pure white as in many other dark brown-coloured species of the genus Capperia but is slightly yellowish as in C. lorana (this feature agrees with Fuchs's description for C.geodactyla), but lorana is much smaller and more greyish coloured. The roundish tuft of scales is present on the tip of the third feather of the secondaries.

I have compared the copulatory apparatus of specimens from Poland and Switzerland and they are identical. Valva nearly of the same breadth at both ends. The flap on the valva projects towards the base of the valva. It is a quite large, elongate piece, rounded at the end. The end part of the valva bluntly cut off and provided with a small, shapeless processus at its ventral part. The aedeagus symmetrical, S-shaped, enlarged at the end part; the small incision present on its tip. The ninth tergum is pointed, large, covers the small tenth tergum which is joined with it. The ninth sternum completely covers the rest of the copulatory apparatus on the ventral side. Female copulatory apparatus similar to $C$. fusca. Ostium bursae having also a small rounded plate as in fusca, but the ostium is placed in the middle of this plate, not on the edge. This plate is surrounded with a much larger sclerotized ring than in fusca. The eighth sternum is wider and more bluntly ended than in fusca. 
The following authors give data concerning the ecology and the morphology of the early stages of trichodactyla: Hübner (I790, I802-I805), Illiger (I80I), Treitschke (I833), Stange (I882, I886), Hofmann (I896, I8981), Klemensiewicz (I90I). All agree with my own observations on the Polish specimens and concern only the species of Capperia feeding on Leonurus cardiaca. The habits of the larva are very interesting. The species appears in two generations. After hibernation the young larvae of the first generation gnaw off the top surface of the leaf-stalk causing one or more leaves to wither and hang loosely. Between the folds of these leaves the larvae hide during windy or rainy weather or while moulting. Sometimes they change there into pupae, but this seldom happens. They feed only when there is no wind or sun. During the month of May the larvae feed on the healthy top leaves, which they perforate. They feed to some extent on withered drooping leaves also. The green or brown pupae are free, nearly always attached head downwards to the leaf-stalks or main stem of the plant. The pupal stage is very short, lasting about ten days only. Imagines fly during the month of June and lay their eggs on flower-buds. The young larvae of the second generation feed inside the calyx, eating out its contents and spinning the lids closing the entrance to the calyx. As the larvae become larger they go out and feed openly on the buds and flowers. They are, however, scarcely visible because they are green, with greyish hairs and very slow moving and resemble parts of food-plant. The larvae feed mostly on the flowers, but sometimes they pass on to the small leaves of the flower-shoots and destroy these leaves, as do the spring generation. The development of the summer generation is very fast and in the middle of July one can see the freshly emerged imagines. They are on the wing until the beginning of August. The imagines live hidden and it is difficult to find them. They are not attracted by white light and because of this it is difficult to capture them with a lamp. In the month of August the young larvae appear. They feed on the leaves of the flower-shoots. By this time the plants are already fruiting and have become dry, and because of this the new larvae grow very slowly. When deprived of fresh food the larvae go down to the lower parts of the plant and with the advance of autumn prepare themselves for hibernation. A couple of times I have found larvae in September on freshly flowering shoots of Leonurus which probably were damaged in the spring and could not flower at the proper time but much later. These larvae were much larger than usual at this time and some of them were nearly full fed. Unfortunately I could not breed the imagines (third generation?) because all these larvae were parasitized by Braconids. The Braconids produced one clear-yellow cocoon for each Plume larva.

The existence of trichodactyla seems to be dependent upon the lime content of the soil where Leonurus grows. In sandy-clayey places near Warsaw trichodactyla appears only in places where the soil is artificially limed, as in farm-yards, hedges visited by poultry, in back-yards and rubbish-heaps, in dusty verges where the road surface is of limestone, around farm-buildings and lime-washed walls. In such places the larvae of trichodactylus were found. In nearby places, where the soil had had no addition of lime, no larvae of trichodactyla were found, although there was abundant growth of Leonurus. On the other hand, on the natural calcareous areas in the neighbourhood

I Excluding 'Ox. leonuri var. fusca', which is a distinct species (vide Capperia fusca (Hofmann)). 
of Lublin (southern part of central Poland) trichodactyla was found everywhere on Leonurus even in deserted places where roads and buildings did not exist.

Geographical distribution. Capperia trichodactyla Denis et Schiffermüller is recorded under various names from Poland, Switzerland, Germany, Austria, Hungary, Macedonia, and Finland. The appearance of this species in Poland, Switzerland, Germany, and Austria is doubtless. It is doubtful if trichodactyla really exists in Macedonia and Hungary. Rebel's determinations are particularly doubtful in this group. The recorded appearance of trichodactyla in Finland should be verified as it is unusual for this species to be found so far northwards. In Poland this species was recorded by Klemensiewicz from Lwów and I verified these data. I observed trichodactyla in Poland in the following localities: Inowrocław, Kruszwica (distr. Inowrocław) ; Podkowà-Leśna (distr. Błonie); Ożarów, Powsin, Obory, Służew, Ursynów (distr. Warszawa); Wał-Miedzeszyński, Dworzec-Wschodni (Warszawa City) ; WolaŁychowska, Gośniewice, Jasieniec (distr. Grójec) ; Wałowice (distr. Kraśnik); Sławinek (distr. Lublin).

\section{Capperia fusca (Hofmann), $\mathrm{I} 898$}

$$
\text { (P1. 9, figs. 5, 5a ; P1. II, fig. I4; P1. I5, fig. 3I ; P1. I9, fig. 54) }
$$

Pterophorus obscurus Zell., Frey, 1856, Tin. Pteroph. Schweiz: 4 Io.

Oxyptilus obscurus Z., Frey, 1880, Lep. Schweiz: 429-430.

Oxyptilus leonuri Stange, Hofmann, I896, Ber. Naturw. Ver. Regensburg. 5: I20-I2I (partim).

Oxyptilus leonuri Stange, var. fusca Hfm., Hofmann, I898, Ill. Zeitschr. Ent. 3: 339-340.

Oxyptilus leonuri Stange, v. fusca Hofm., Rebel, I901, Cat. Lep. Pal. 2: 7 I.

Oxyptilus leonúuri Stange, v. fusca Hofm., Spuler, I910, Schmett. Eur. 2: 324.

Oxyptilus leonuri Stange, Meyrick, 1913, Lep. Cat. 1\%: 7 (partim).

Oxyptilus parvidactylus, Vorbrodt, I93I, Ivis, 45: I24 (partim).

Oxyptilus fuscus O. Hofm., Brinkmann \& Amsel, I936, Mitt. Ent. Ver. Bremen, 23: I4 (?).

Oxyptilus leonuri Stange, f. fusca Hofmann, Lhomme, 1939, Cat. Lep. France, 2: 178-179.

Examined material:

I. Female specimen from France (Coll. Hofmann, British Museum, London): 'Cotype', 'Z.6.6.97, Moulineaux, Gallia', 'Hofmann Coll., Walsingham Collection 1930-427', 'Oxyptilus leonuri St. var. fusca Hfmn., Named by O. Hfm.', 'Praep. no. Ox. I Io' (praep. genit.).

2. Female specimen from France (Coll. Hofmann, British Museum, London): 'ir.6.97', 'Oxyptilus leonuri St. v. fusca, e. coll. Hofmann'.

3. Female specimen from France ex coll. Constant (Lhomme Coll., Le Carriol, France): 'T. 97, leonuri v. fusca, Moulineaux'.

4. Male Swiss specimen ex coll. Frey (British Museum Coll., London) : 'Frey Coll. Brit. Mus. I890-62', 'Zürich e. I.', 'I947/60' (praep. genit.). (This specimen and some others from the same series from Frey collection are determined in the British Museum as Oxyptilus parvidactylus Hw. (= obscurus Z.).)

5. Male specimen from Tatra Mts. (Mus. Zool. Polon. Coll., Warsaw): 'Tatry, Przysłup Miętusi (I I50 m.), 4.viii.I936, leg. E. Swiderski', 'praep. genit. no. Ox. 55.'

6. Female specimen from East Carpathians Mts. (Mus. Zool. Polon. Coll., Warsaw): 'Las Swiniarki, distr. Kosów Pokucki (6oo m.), I 7.viii.I935, leg. S. Adamczewski', 'praep. genit. no. Ox. $75^{\prime}$.

7. Male specimen from East Beskid Mts. (in the Carpathians Mts.) (Physiographical Mus. Coll., Cracow): 'Pod Makowicą, ad Rytro ( \pm 600 m.) I4.viii.r9o3, leg. S. Klemensiewicz', 'praep. genit. no. Ox. 59.' (F. Schille det.: Ox. leonuri Stange.) 
8. Female specimen from East Beskid Mts. (in the Carpathians) (Physiographical Mus. Coll., Cracow): 'Rytro, I89, 377, ex coll. F. Schille', 'Praep. genit. no. Ox. 6I' (F. Schille det.: Ox. parvidactylus $\mathrm{Hw}$.$) .$

9. Male specimen from neighbourhood of Cracow (Mus. Zool. Polon. Coll., Warsaw) : 'Dolina Bentkowska ad Ojców ( \pm 400 m.), I8.vii.r935, leg. A. Starczewski', 'Praep. genit. no. Ox. 97.'

Io. Sixty-five specimens from neighbourhood of Cracow (Mus. Zool. Polon. Coll., Warsaw): 'Dolina Sąspowska ad Ojców, 3o.vii.-I2.viii.r942 ex larva, Stachys alpina, leg. S. Adamczewski'.

I I. Male specimen from neighbourhood of Zawiercie (south Poland) (Mus. Zool. Polon. Coll., Warsaw): 'okolice Zawiercia, leg. M. Isaakowa, ex coll. L. \& M. Masłowski'.

This species has been known since I856 when Frey described its early stages but erroneously determined it as 'obscurus Z.' and later (I880) as 'parvidactylus Hw.' Hofmann (I896) was the first to observe that fusca was distinct from parvidactylus, but he wrongly considered it to be only a form of 'leonuri Stange'. Subsequently Hofmann examined a series of bred specimens from northern France which were identical with Frey's specimens from Switzerland and on the basis of this material he described (I898) 'Oxyptilus leonuri Stange var. fusca Hfm.', but he erroneously stated that the aedeagus of leonuri and of fusca were not distinct. This mistake of Hofmann's was continued by other entomologists until the present times. Only M. Hering has used the name 'Oxyptilus fuscus O. Hofm.', in determining a specimen from Bassum near Brema, sent to him for determination by Amsel (Brinkmann and Amsel, I936). I did not see this specimen, but it is possible that it was a form very similar to fusca but feeding on Marrubium vulgare (see Capperia fusca Hofmann, n. forma marrubii). This Marrubium-feeding form was bred by Glitz in Hanover (Rössler, I88I ; Frey, I886). For the correct determination of this specimen from Bassum one must know whether the food-plant of $C$. fusca, which is Stachys alpina, occurs in the neighbourhood of Brema. If, as is possible, this plant does not occur near Brema, then the specimen from Bassum most probably belongs to the form feeding on Marrubium vulgare, which is distributed in NW. Germany.

All examined specimens from Switzerland, France, and Poland, including also the original specimens of Frey and Hofmann, were very dark chocolate-brown coloured, tinted with reddish. It is this reddish tint that best separates it from $C$. trichodactyla (=leonuri), which is also dark brown in colour but with an olive tint. The white pattern on the wings of fusca is strongly reduced so that it seems to be uniformly dark. In general appearance Capperia fusca resembles the darkest forms of Oxyptilus parvidactylus. C. fusca is one of the smallest species in its genus, the wing span being I3-I $5 \mathrm{~mm}$. The specimens of the summer generation are smaller than those of the spring generation. The ecological data and the descriptions of the early stages of Swiss and French specimens agree with my observations on the Polish material. Also the identical structure of the genitalia shows that all the material examined from central and western Europe belong to the same species.

Male genitalia. Valva nearly straight, ovally enlarged anteriorly (i.e. in the basal part) but narrowed posteriorly. The flap on the valva projecting towards its anterior end is vertically cut on the tip. The ninth tergum is pointed at the end. The ninth sternum large, strongly sclerotized, covering the rest of the copulatory apparatus on 
the ventral side. Aedeagus very characteristic, distinguishing C. fusca from all the species except marrubii which is very similar in form; it is strongly sclerotized, curved like an 'S', a bilaterally asymmetrical organ. On the right side, on the posterior part of aedeagus there is a very large vertical spine. C. fusca form marrubii has a similar structure, but its spine seems to be thicker. Female genitalia somewhat similar to C. trichodactyla but distinct. The end of the eighth sternum of fusca is more slender and not so large as in trichodactyla. The plate covering the ostium bursae is flat, round, with the ostium opening symmetrically at the base of the plate, while in trichodactyla the plate is formed like a ring asymmetrically placed on one side of the ostium.

Descriptions of the early stages have been given by Frey (I856) and by Hofmann (I898). Specimens from Poland agree with these descriptions. The nearly fully fed larva is green, whitish hairy like trichodactyla, but it has a head which is black, not greenish with dark spots as in trichodactyla. Like other species of the genus Capperia it seems to be monophagous, feeding on Stachys alpina. (The taxonomic position of the form marrubii which feeds on Marrubium is not yet certain.) Larvae of fusca transferred to the closely allied Stachys silvatica died; they did not touch this food. The larvae appear twice a year. The spring specimens feed after hibernation on the stems and lower leaves, becoming full fed in the second half of May. The pupae are attached to the stems or below the leaves. The imagines appear in the first half of June. The larvae of the second generation become fully fed in the middle of July. They feed on the flowers, eating out the flower-buds, and change into pupae inside the calyx. The pupae are dark brown, nearly black, or green-brown coloured. The second generation of imagines emerges in the second half of July and in August. In southern Poland this species frequents shady beech forests growing on chalky ground (Jurassic rocks) where Stachys alpina occurs. It was observed in the Tatra Mts. at an altitude of I,I50 m., but in the Swiss Alps according to Frey it occurs up to $\mathrm{I}, 800 \mathrm{~m}$. It has been recorded from northern France in the neighbourhood of Rouen. Lhomme (I939) cites it from French Alps and Pyrenees.

\section{Capperia fusca Hofmann, nova forma marrubii}

$$
\text { (P1. I9, fig. 55) }
$$

Pterophorus dentellus Mann, Zeller, I852, Linn. Ent. 6: 354 (?).

Oxyptilus parvidactylus Hw., Rössler, I88I, Jb. Nassau Ver. Naturk. 33-34: 22 (partim).

Oxyptilus parvidactylus Hw., Steudel \& E. Hofmann, I882, Jh. Ver. vaterl. Naturk. Württemb. 38: 246.

Oxyptilus hievacii Z., Frey, I886, Stettin. Ent. Ztg. 4\%: I8 (partim).

Oxyptilus teucrii var. celeusi (Schmid) Frey, O. Hofmann, 1896, Ber. Naturw. Ver. Regensburg. 5: I 8 (partim).

Oxyptilus parvidactylus Hw., Reutti, Meess, \& Spuler, I898, Lep. Baden: I5I (partim).

Oxyptilus teucrii (Greening) Jordan, Reutti, Meess, \& Spuler, I898, Ibid.: 152 (partim).

Oxyptilus parvidactyla Hw. ab. dentellus (Mann) Zell., Tutt, 1907, Brit. Lep. 5: 418.

Oxyptilus teucrii var. celeusi Frey, Spuler, 1910, Schmett. Eur. 2: 325 (partim).

Oxyptilus fuscus O. Hofm., Brinkmann \& Amsel, 1936, Mitt. Ent. Ver. Bremen, 23: I4 (?).

Oxyptilus heterodactylus var. celeusi Frey, Lhomme, 1939, Cat. Lep. France, 2: 79 (partim).

ENTOM. I, 5 . 
Examined material:

I. Male specimen from Württemberg, ex coll. O. Hofmann (British Museum, London): 'Urach, Marrubium', 'I947/106' (praep. genit.) (in Hofmann coll. det. as 'teucrii var. celeusi Schm.').

2. Male specimen from Württemberg, ex coll. O. Hofmann (British Museum, London): 'Urach, Marrubium' (in Hofmann coll. det. as 'teucrii var. celeusi Schm.').

3. Female specimen from Croatia (British Museum, London): 'P. Dentellus Mann $=$ obscurus, Croatien, Gromnig', 'Frey coll., Brit. Mus. I890-62', 'I947/9' (praep. genit.).

4. Female specimen from Greece (Polish Museum of Zoology, Warsaw): 'Graecia (Tessalia), Tembi near Olimp Mt. 2I.vii.r938, leg. S. Adamczewski', 'praep. genit. Ox. I I6.'

Specimens of this form, feeding on Marrubium vulgare, were found for the first time by Glitz near Hanover (Rössler, I88I ; Frey, I886). I can trace no publication by Glitz himself. Rössler (I88I) considered that Glitz's specimens were of a species distinct from Oxyptilus parvidactylus Hw. because of their distinct life-history, but he did not name this Marrubium-feeder. Steudel and E. Hofmann (I882) cited 'Oxyptilus parvidactylus Hw.' from 'Urach am Wasserfall Juni, Juli, Herbst. Raupe im Spätsommer an den Blüthen von Marrubium'. Frey (I886) considered the specimens of Glitz from Hanover, of Schmid from Bavaria and of Jordan from England as Oxyptilus hieracii. In this way he united three different species of the genus Capperia feeding on different food-plants with a fourth species from another genus differing very much in its life-history. O. Hofmann (I896) cited the data published by his brother with Steudel (I882). Reutti, Meess, and Spuler (I898) in their description of the lepidopterological fauna of Baden erroneously recorded 'Marrubium blüthen' as the food-plant of 'Oxyptilus parvidactylus Hw.' and Marrubium vulgare and Teucrium scorodonia as food-plants of 'Oxyptilus teucrii (Greening) Jordan'. Spuler (I9I0) mentioned Teucrium chamaedrys and Marrubium peregrinum as food-plants of 'Oxyptilus teucrii var. celeusi Frey' from Württemberg and Bavaria. It is not clear why Spuler changed the commonly used name Marrubium vulgare to Marrubium peregrinum which had not been previously mentioned in lepidopterological literature. Lhomme (I939) recorded 'Oxyptilus heterodactylus Vill. var. celeusi Frey' from a single locality in France and he cited (evidently taken from literature) as the foodplants of this form Teucrium botrys, Teucrium chamaedrys, Marrubium vulgare, Marrubium peregrinum. None of these statements has anything to do with Oxyptilus parvidactylus and all refer to some different species of Capperia. The specimens recorded from Marrubium vulgare, as was proved, had quite an asymmetrical aedeagus different from those of specimens from Teucrium chamaedrys and T. scorodonia, which belong to two Capperia species with a symmetrical aedeagus. I consider all the published records concerning the form feeding on Marrubium vulgare to refer to the distinct form Capperia fusca Hofmann, nova forma marrubii. Possibly it is a quite distinct species, but it needs further investigation. Specimens from Marrubium peregrinum were not examined, and it is not certain if such specimens ever existed. Marrubium peregrinum was mentioned as the food-plant of celeusi for the first time by Spuler (I9IO), but he said nothing about Marrubium vulgare, previously recorded by Rössler and Hofmann. It is very probable that Spuler, collecting data from the literature, changed the name only, and that his record of Marrubium peregrinum refers to $M$. vulgare. Lhomme's record of $M$. peregrinum was copied from Spuler. The 
specimen from Bassum near Brema which Hering named 'Oxyptilus fuscus Hofm.' (Brinkmann \& Amsel, I936) probably belongs also to the form marrubii because it is doubtful whether Stachys alpina, which is the food-plant of typical fusca, occurs near Brema.

The description of the form marrubii is founded on two specimens from the collection of O. Hofmann labelled 'Urach, Marrubium' and placed under the name 'teucrii var. celeusi Schm.' They are the specimens bred by E. Hofmann on Marrubium vulgare, mentioned by O. Hofmann (I896) and by Reutti, Meess, and Spuler (I898). The specimen of which the genitalia was examined (no. I947/I06) is designated as Holotype.

External appearance. Wing-span I4 mm. In shape and size marrubii is similar to typical $C$. fusca, but in colour it is nearer to C. celeusi. The ground colour of the wings is brown with a yellowish tint similar to the specimens of celeusi from Bavaria. The dark chocolate-brown colour with the reddish tint characteristic of fusca is absent in marrubii, so it is not very difficult to distinguish these two forms. From similarly coloured celeusi, marrubii differs in its more dumpy structure which is similar to that of fusca. The third feather of hind wing of marrubii is whitish in the middle, while in fusca this feather is completely dark. In the tuft of scales on third feather in marrubii the scales on the hind margin are longer than those on the fore margin, while in fusca the scales in the tuft are of the same length on both sides.

Male copulatory apparatus seen in situ is very similar to that of fusca. Aedeagus a little wider and thicker than in fusca. It is provided with the spine on the right side of its posterior part, but this spine seems to be a little thicker than in fusca. The ninth sternum is wider, not so slender as in fusca. The best distinguishing character in the genitalia is in the ninth tergum. It is dully rounded on the tip in marrubii but elongated and pointed in fusca.

Besides these specimens bred on Marrubium I found among some Balkan material two females with genitalia very similar to typical fusca. These females differed from fusca in their external appearance, being much more brightly coloured. The light pattern is more strongly developed than in fusca and the third feather is whitish in the middle. These females differ from the males bred on Marrubium in the greyish tint of their brown wings, and in the better developed light pattern on the wings. These specimens were taken in Greece and Croatia. The specimen from Greece was captured at Tembi in the same place as C. hellenica. It was darker than the second specimen from Croatia, originated from the Frey collection, and bore the old label 'P. Dentellus Mann'. It is possible that it is one of the original specimens of Mann whose unpublished name dentellus was synonymized by Zeller with obscurus (1852). Only after examination of bred material from the Balkan countries will it be possible definitely to determine these two specimens. For the time being one can provisionally place them as the south European form of marrubii.

The early stages of marrubii are not known accurately. The larvae feed on flowers of Marrubium vulgare at the end of summer (Rössler, I88I ; Steudel and E. Hofmann, I882). The larva is probably similar to celeusi, i.e. green with the black head, if the brothers Hofmann who knew both forms did not notice any difference between them.

Geographical distribution. C. fusca Hofmann, nova forma marrubii is known cer- 
tainly from western Germany: Hanover (Rössler, I88I, leg. Glitz) and Württemberg (Steudel and E. Hofmann, I882). Its presence in the Balkan States is uncertain. Possibly it may occur in the neighbourhood of Brema (vide $C$. fusca) and in France (Lhomme, I939).

\section{Capperia tamsi, sp.n.}

Examined material:

$$
\text { (Pl. I9, fig. 56) }
$$

I. Male specimen (Holotype) from Asia Minor (British Museum, London): 'Alma Dagh, Asia Minor, J., o6.'; Oxyptilus ? marginellus Z., E. Meyrick det. in Meyrick Coll.'; 'I947/3' (praep. genit.).

2. Male specimen (Paratype) from Syria (British Museum, London): 'Shar Deresy, Syria I893, Leech, Nat. Coll. 61529'; 'Walsingham Collection I910-427'; 'r947/7' (praep. genit.) (det. in the British Museum Coll. as 'Ox. tristis Z.').

3. Male specimen (Paratype) from Andalusia (British Museum, London): 'Andalusia, Staudinger nr. 62I, 6.ii.r895, nr. 6I69'; 'Walsingham Collection r910-427'; 'Oxyptilus hoffmannseggi Möschl., named by Stgr.' ; 'I947/14' (praep. genit.) (det. in the British Museum Coll. as 'Ox. marginellus Z.').

This species was discovered whilst studying the material of Capperia marginella Zeller and Oxyptilus hoffmannseggi Möschler. These two species, although belonging to different genera, were synonymized, and series of various species determined with these names form a strange mixture in many. collections. Before describing Capperia tamsi I must give some notes on the names marginella and hoffmannseggi and their meaning. Above all they are not synonyms as Meyrick stated in his Catalogue (I9I3). Capperia marginella Zeller is known from Sicily only. All other examined material of marginella from various collections was wrongly named. C. marginella belongs to the group of species in the genus Capperia having asymmetrical male genitalia. In spite of the great similarity in the external appearance Capperia tamsi belongs to the other group with symmetrical genitalia and has nothing to do with C. marginella. Oxyptilus hoffmannseggi Möschler is even more distinct and completely different from both marginella and tamsi. Möschler described this species from Andalusia and gave some very characteristic particulars. He wrote: 'der Afterbüschel braun, weiss gemischt' and 'die drei Lappen der Hinterflügel dunkelroth braun, der hintere weiss bestäubt, vor der Spitze schwarzbraun beschuppt. Franzen graubraun in der Spitze des hinteren Lappens weiss.' and 'Unten der innere Lappen ganz weiss.' This description settles the correct position of hoffmannseggi: it is an Oxyptilus having the 'Afterbüschel' and also some other features agreeing very well with specimens belonging to Oxyptilus, not to Capperia. Specimens of the genus Capperia erroneously named as hoffmannseggi have the tip of their third feather always dark, not white. The specimens of $C$. tamsi also were confused with hoffmannsegg $i$ because they have the white scales on the tip of the third feather, but their cilia are dark on the tip, not white, as in hoffmannseggi. Möschler in his description cited the opinion of Wocke that specimens occur in S. France similar in appearance to the Spanish hoffmannseggi. I examined a specimen from Constant's collection (probably from S. France) named as hoffmannseggi, but it was $C$. celeusi. In the Walsingham collection I found a specimen labelled 'Ox. hoffmannseggi? Millière, Cannes I883'. This specimen (wing-span ${ }_{5} \mathrm{~mm}$.) 
was an Oxyptilus similar to darker coloured specimens of Oxyptilus parvidactylus from central Europe; however, it has many white scales in the middle of its third feather as in hoffmannseggi, and on the tip of this feather there are also white hairs on the cilia but not so numerous as in hoffmannseggi. I did not see Möschler's types, but two specimens from Spain named by Staudinger as hoffmannseggi, which I examined, doubtless belong to this species, completely agreeing with Möschler's description. These specimens are in O. Hofmann's collection and labelled as follows: 'Castil. St. 85' and 'Hisp. Stgr. 98'. They are both Oxyptilus. Their male genitalia are similar to those of parvidactylus with very small second lobes of the valvae. These specimens are light brown coloured, pale, with a greyish tint. We find in the much darker coloured, dark brown specimens from Asia Minor and Syria again genitalia similar to the parvidactylus group. They might belong to hoffmannseggi or to allied but not yet distinguished species. Staudinger did not notice the differences between the forms belonging to Oxyptilus and to Capperia and named as hoffmannseggi also some Capperia species (as, for example, the specimen no. 'I947/I4' of tamsi). His publication of $\mathrm{r} 88 \mathrm{o}$ gives some very strange opinions. He synonymized parvidactylus with hoffmannseggi and marginellus. He doubts whether maculatus and teucrii are distinct, and even the distinctness of hieracii, pilosellae, and ericetorum seem to be doubtful to him. Rebel (I90I) partially continued Staudinger's errors and he put marginellus in his catalogue with an interrogation mark as a species doubtfully distinct from parvidactylus; hoffmannseggi he considered as the synonym of marginellus. Meyrick (I9I3) considered marginellus as distinct from parvidactylus, but hoffmannseggi still remained as a synonym of marginellus in his opinion. It seems strange that neither author could separate these two species belonging to two distinct genera. In the Meyrick collection there are two specimens from Asia Minor from the same locality, named '? marginellus'. One of them is C. tamsi (no. I947/3); the other is an Oxyptilus very close to the hoffmannseggi dark form discussed above. Caradja, discussing the species of this group (I920) from the Middle East countries (Amasia, Malatia, Erivan, Kasikoparan), did not mention marginella at all but only hoffmannseggi. Among this material there was an especially 'large form' resembling maculatus (in the opinion of Caradja, of course). In the Walsingham collection there is a series from Syria probably corresponding to the 'large form' of Caradja. One of these Syrian specimens was $C$.tamsi (no. I947/7), but all the others belong to the above-mentioned dark form of hoffmannseggi (praep. genit. no. I947/I02). The wing-span of these specimens is $15-18 \mathrm{~mm}$. This form is allied to hoffmannseggi and to parvidactylus. It may be small but sometimes is very large. Thus Oxyptilus hoffmannseggi and its as yet unnamed dark form occur in Spain, Asia Minor, and Syria. Maybe the abovementioned specimen from southern France (Cannes) belongs here also. Capperia tamsi is known from the same countries as hoffmannseggi, but $C$. marginella has never been found in any of these countries.

External appearance. Capperia tamsi is of medium size in its genus. The wing-span I6 $\mathrm{mm}$. (Syria), I7 mm. (Andalusia), I7.5 mm. (Asia Minor). It is dark brown in colour but differs in tone. The specimen from Andalusia shows a greyish tint, that from Asia Minor a reddish tint; the darkest one seems to be the specimen from Syria, but it is very worn. On the hind margin of the second feather of the hind wing there 
is a very distinct white spot in the middle of the cilia. On the tip of the third feather single white scales are present. The cilia at the tip of the third feather are dark, not white as in hoffmannseggi.

Male genitalia. Aedeagus strongly sclerotized. In comparison with the other species of the genus Capperia it is weakly curved like an ' $S$ ' and not much thicker in the middle than at both its ends. It is symmetrical and not bifurcated but straightly elongated at the posterior end. Valva strongly sclerotized, strongly arched, narrow near its base, but 2-3 times wider at its posterior end than at its base. The posterior half of the valva is strongly hairy on its inner surface. The folds and flaps of the valvae very weakly developed, projecting outside of valva and not folded on its surface as in other allied species. The ninth tergum weakly developed in the form of the triangular flap with pointed tip without incision. The ninth sternum short, not reaching farther than $\frac{3}{4}$ of the length of the valva. It is a very thick plate with some traces of its former vesicular structure (see genus Procapperia). The posterior part of this plate is bifurcate and bluntly cut at the tip; this top part is strongly hairy on its interior side. The genitalia of $C$. tamsi show a very interesting transition between the structure of the genus Procapperia and the more specialized and developed species of the genus Capperia. In connexion with this the structure of the valva, the ninth sternum and aedeagus is especially interesting. Female of $C$. tamsi is unknown.

Early stages and food-plant unknown.

Geographical distribution. Spain, Asia Minor, Syria.

\section{I0. Capperia raptor (Meyrick), I908}

Oxyptilus raptor sp.n., Meyrick, I908, Trans. Ent. Soc. Lond. 40: 478.

Oxyptilus raptor Meyr., Meyrick, 1913, Lep. Cat. 17: 8 (partim ?).

Pterophorus raptor Meyrick, Barnes \& Lindsey, I92I, Contr. Nat. Lep. Amer. 4: 304-305, pl. 4I, fig. 6 ; pl. 49 , fig. 3 .

Pterophorus raptor Meyr., McDunnough, 1926, Rep. Ent. Soc. Ont. 25: 49.

I have not examined this species. It is classified in this place on the basis of the figure of the male genitalia given by Barnes and Lindsey (I92I). From the descriptions of these authors, it appears they had not examined the Meyrick type of raptor; it should be verified that the male figured by them belongs to the same species as the Meyrick's type specimen, which is a female. The male copulatory apparatus figured by Barnes and Lindsey is most similar to that of tamsi. These two species form a group apart from all other species of Capperia. Valva with long pointed flap projecting beyond and not lying along the valva as in other species. Aedeagus without processes, curved like an ' $S$ ', but not so strongly as in other Capperia species. The ninth sternum bifurcate at its posterior end; the two parts of this bifurcation rounded at the tip, as in tamsi, and not pointed as in other species. The ninth tergum in the form of a triangular flap.

The early stages and the food-plant unknown.

Distributed only in northern America as follows: Colorado (Meyrick, Barnes, and Lindsey), Indiana (Barnes and Lindsey), Canada (McDunnough). Meyrick cited also (I9I3) California, but Barnes and Lindsey referred the Californian record to other species. 


\title{
II. Capperia hellenica, sp.n.
}

\author{
(Pl. I6, figs. $35,36,37$ )
}

Pterophorus obscurus Zeller, I847, Isis, 40: 38 .

Pterophorus marginellus sp.n. Zeller, 1847, Ibid. 40: 904 (partim).

Examined material:

I. Holotype (ठ઼) from Greece (Coll. Mus. Zool. Polon., Warsaw): 'Graecia, Tessalia, Tembi 2I-25.vii.r938, leg. S. Adamczewski'; 'Capperia hellenica, Adam., Holotypus, praep. genit. no. Ox. ro9'.

2. Allotype (ㅇ) from Greece (Coll. Mus. Zool. Polon., Warsaw): 'Graecia, Tessalia, Tembi 21-25.vii.r938, leg. S. Adamczewski'; 'Capperia hellenica, Adam., Allotypus, praep. genit. no. Ox. ro4'.

3. Five paratypes from Greece (Coll. Mus. Zool. Polon., Warsaw): 'Graecia, Tessalia, Tembi 2I-25.vii.1938, leg. S. Adamczewski'.

4. Female specimen from Yugoslavia, ex coll. Schawerda (Coll. Kolon. Museum, Bremen): 'Hercegovina, Bišina, I I.viii., marginellus Z., Rebel det.'

5. Male specimen from Yugoslavia, ex coll. Meyrick (Coll. British Museum, London): 'Ragusa, Dalmatia, L., vii.o7.'; 'near Oxyptilus intercisus Meyr., E. Meyrick det. in Meyrick coll.'; 'Meyrick Coll. B.M. I938/290'; 'I947/66' (praep. genit.).

6. Female specimen from Italy, ex coll. Walsingham (Coll. British Museum, London): 'Italy, Ps. de Grey'; 'Walsingham coll. I910-427'; 'I947/15' (praep. genit.), (det. in the British Mus. Coll. as 'marginellus Z.').

7. Male specimen from southern France, ex coll. Millière (Coll. Brit. Museum, London): 'Cannes, S. France, Millière I88 . .' ; 'Óx. evicetorum Z., Cannes, Millière'; ' I/9'; 'Walsingham coll. I910-427'; ‘ $1947 / 6$ ' (praep. genit.) (det. in the British Mus. Coll. as near leonuri Stange).

8. Male specimen from France, ex coll. Millière (Coll. British Museum, London): 'Cannes, S. France, Millière, vii.r885'; 'Oxyptilus marginellus Z.'; 'Walsingham Collection I9ro427'; 'r947/I I' (praep. genit.).

9. Female specimen from Asia Minor, ex coll. Zeller (Coll. Brit. Museum, London) : 'marginellus Z. Macri, Löw'; 'marginellus Z., Cotype'; 'Zeller Coll., Walsingham Coll. I910-427'; 'r947/10' (praep. genit.).

Capperia hellenica is one of the smallest species in its genus. The wing-span is Io-I4 $\mathrm{mm}$. Probably specimens of the spring generation are larger. It is one of the lightest coloured species. The yellow-brown ground colour recalls $C$. zelleri. The tuft of scales on the third feather is rounded as in $C$. zelleri. The feathers of the fore wings are narrower and more delicate than those of zelleri, rather resembling those of Procapperia croatica.

Male genitalia. Valva strongly arched with rounded tip and more or less of the same width at the anterior and posterior ends. The flap on the valva projects anteriorly. It is elongated but rounded at the tip. Aedeagus curved like an ' $S$ ', symmetrical, without spines, processes, and bifurcations. It becomes narrower posteriorly and its tip is pointed as in the species of the genus Procapperia. The ninth tergum bluntly ended. The ninth sternum broad, ending with two pointed flaps reaching as far as the tips of the valvae. Female genitalia of hellenica approaching those of Procapperia croatica. Ostium bursae only strongly sclerotized near outlet. It is visible under the eighth sternum as a little rounded dark spot. The eighth sternum is in the form of a triangular flap elongated posteriorly and more strongly sclerotized at the tip.

The early stages and the food-plant unknown. 
I captured the imagines of this species in Greece on herbs after sunset in a mulberry grove along the river Tembi near the village of the same name. Unfortunately the herbarium containing the specimens of the probable food-plants was destroyed during the war before determination.

Geographical distribution. South France, Italy, Yugoslavia, Greece, Asia Minor.

\section{I2. Capperia lorana (Fuchs), I895}

(P1. 9, fig. 2; Pl. I2, fig. 2I)

Oxyptilus obscurus Z., Rössler, I866, Jb. Nassau Ver. Naturk. 19-20: 263 (partim).

Oxyptilus parvidactylus Hw., Rössler, I88I, Ibid. 33-34: 222 (partim).

Oxyptilus loranus sp.n., Fuchs, I895, Stettin. Ent. Ztg. 56: 48-50.

Oxyptilus teucrii (Greening) Jordan var. celeusi Frey, Hofmann, I896, Ber. Naturw. Ver. Regens-

burg. 5: Ir6-119, figs. 2, $9 a b$ (partim).

Oxyptilus loranus Fuchs, Fuchs, 1897, Stettin. Ent. Ztg. 58: 338-339.

Oxyptilus teucrii Jordan v. lovanus Fuchs, Rebel, I9or, Cat. Lep. Pal. 2: 7 I.

Capperia heterodactyla var. loranus Fuchs, Tutt, 1907, Brit. Lep. 5: 272-275.

Oxyptilus loranus Fuchs, Spuler, 19ro, Schmett. Eur. 2: 325.

Oxyptilus heterodactylus de Villiers, Meyrick, I9Io, Gen. Ins. 100: 7 (partim).

Oxyptilus heterodactylus de Villiers, Meyrick, 1913, Lep. Cat. 1\%: 7 (partim).

Oxyptilus loranus Fuchs, Hering, I932, Tierwelt Mitteleur., Ergänzb. 1: I64.

Examined material:

I. Male specimen from Fuchs collection (Coll. Magyar Nemzeti Muzeum, Budapest): 'Bornich 23.7.97. Rieslingbg.' ; 'lovanus, coll. Eppelsh.'.

2. Male specimen from Fuchs collection (Coll. Magyar Nemzeti Muzeum, Budapest): 'Lennig I6.6.I896, Rieslingbg.' ; 'Bornich, Fuchs' ; 'lovanus, coll. Eppelsh.' ; ‘ praep. genit. Ox. I05.'

3. Specimen without abdomen from O. Hofmann coll. (British Museum, London): 'Bornich I2.7.95, Rieslingb.'; 'Loranus, Fuchs' (probably one of cotypes, male, which genitalia were examined by Hofmann (1896)).

Capperia lorana Fuchs is easily distinguishable by its external appearance and also by the characteristic structure of the male genitalia. Unfortunately Hofmann (I8g6) published an erroneous observation that lorana and celeusi were identical in their genitalia and thus misled later entomologists. Subsequently this erroneous synonymy of Hofmann was accepted and perpetuated by Rebel (I9oI) and Meyrick (I9I0, I9I3). Since the collection of Fuchs had been distributed amongst various collections (Horn, I926), it was difficult to find the type of lovana. Looking through the collections of the Hungarian Museum in Budapest I found two original specimens of lorana labelled by Fuchs. In external appearance they agreed with his description. One specimen was of the spring generation (alar expanse $\mathrm{I} 7 \mathrm{~mm}$.) and the other of summer generation (alar expanse $15 \mathrm{~mm}$.). In accordance with Fuchs's description these specimens were greyish coloured like Oxyptilus tristis, and had the bands and light pattern on the wings slightly yellowish and not pure white as have most species in the genus Capperia. This yellowish tint gives this species an appearance resembling that of trichodactyla; but by comparison it is smaller and more brightly coloured. In general appearance, however, lorana resembles most closely the grey form of celeusi from Podolia and Thuringia.

Male genitalia. The aedeagus is very characteristic. It is strongly curved like an ' $S$ ', heavily sclerotized and terminates with an asymmetrical plate provided with 
two big teeth. The valva is very contracted in the middle and is wider at the end than at its base. The flap on the valva projects in towards its base and is long, narrow, and rounded on the tip. The ninth tergum is triangular and bluntly ended posteriorly. The ninth sternum is narrow and strongly convex towards ventral side. It is bifurcated posteriorly in two long, pointed flaps, which reach to the end of the valvae. The female copulatory apparatus is unknown.

Capperia lorana is double-brooded. The early stages are unknown. Fuchs (I897) states that $C$. lorana in discrimination from teucrii does not live on Teucrium scorodonia but on 'a small plant which flowers in July'. Unfortunately he did not give the name of this. plant.

Geographical distribution. Rhineland only. ${ }^{\mathrm{I}}$

\section{I3. Capperia marginella (Zeller), I847}

$$
\text { (Pl. Io, fig. I3; Pl. I7, figs. 45, 46; Pl. I9, figs. 58, 59) }
$$

Pterophorus marginellus sp.n., Zeller, I847, Isis, 1847: 903-904 (partim).

Oxyptilus marginellus Z., Zeller, 1852, Linn. Ent. 6: 355 (partim).

Oxyptilus marginellus Z., Herrich-Schäffer, 1855, Schmett. Eur. 5: 372-373 (partim).

Oxyptilis marginellus Z., Wocke, I871, Cat. Lep. Eur. 2: 343, no. 3144 (partim).

Oxyptilus parvidactylus var. marginellus Z., Staudinger, I880, Horae Soc. Ent. Ross. 15: 425-427 (partim).

Oxyptilus ?marginellus Z., Rebel, I901, Cat. Pal. Lep. 2: 72 (partim).

Oxyptilus parvidactyla var. marginellus Z., Tutt, 1907, Brit. Lep. 5: 419 (partim).

Oxyptilus marginellus Z., Spuler, 1910, Schmett. Eur. 2: 324 (partim).

Oxyptilus marginellus Zeller, Meyrick, I910, Gen. Ins. 100: 7 (partim).

Oxyptilus marginellus Zell., Meyrick, 1913, Lep. Cat. 17: 7 (partim).

Capperia marginella (Zeller), Adamczewski, I939, Ann. Mus. Zool. Polon. 13: 26r.

Examined material of Capperia marginella:

I. Male specimen, type (Holotype), from Sicily (British Museum, London): 'marginellus Z., Syrac. 23 Mai'; 'Oxyptilus marginellus Z. Is. 47, 903, L.E. 6, 355'; 'Type H.T.' ; ' 1947/I' (praep. genit.).

2. Female specimen (Allotype), from Sicily (British Museum, London): ' marginellus Z., Syrac. 4 Mai'; 'Zeller Coll., Walsingham Collection I9ro-427'; 'praep. genit. no. Ox. 87'.

3. Paratype specimen (probably male) from Sicily (British Museum, London) : ' marginellus Z., Syrac. 4 Mai'; 'Zeller Coll., Walsingham Collection I910-427'.

List of examined specimens erroneously named in various collections as marginellus (the following data are given: correct determination, origin of specimen, who named it as marginella, from what collection):

I. Procapperia croatica Adam., Zengg-Croatia, det. Rebel, Kolonial Museum, Bremen.

2. Procapperia anatolica (Caradja), Amasia-Asia Minor, det. ex coll. Eppelsheim, Magyar Nemzeti Muzeum, Budapest.

3. Crombrugghia distans (Zell.), Asia Minor, det. ex coll. Eppelsheim, Magyar Nemzeti Muzeum, Budapest.

4. Oxyptilus hoffmannseggi Möschler, Alma Dagh, Asia Minor, det. Meyrick, British Musèm, London.

5. Capperia celeusi (Frey), Regensburg, det. Zeller (vide Herrich-Schäffer, Schmett. Eur. 5: 372).

I Of course Rebel's statement (I9I6) that Ox. teucrii loranus occurs in 'Hungary' (Croatia, Zengg) cannot refer to $C$. lorana Fuchs. These specimens most probably were Procapperia croatica.

ENTOM. I, 5 . 
6. Capperia washbourni Adam., Shar Deresy, Syria, det. Walsingham, British Museum, London.

7. Capperia washbourni Adam., Jericho, Palestine, det. Rebel, Kolonial Museum, Bremen.

8. Capperia fletcheri Adam., Jerusalem, Palestine, det. Rebel, Kolonial Museum, Bremen.

9. Capperia tamsi Adam., Alma Dagh, Asia Minor, det. Meyrick, British Museum, London.

ı. Capperia hellenica Adam., Bišina, Hercegovina, det. Rebel, Kolonial Museum, Bremen.

I I. Capperia hellenica Adam., Macri, Asia Minor, det. Zeller, British Museum, London.

I2. Capperia hellenica Adam., Cannes, France, det. ex coll. Millière, British Museum, London.

I3. Capperia hellenica Adam., Italy, det. Walsingham, British Museum, London.

I4. Capperia zellevi Adam., Sicily, det. Zeller, British Museum, London.

I5. Capperia maratonica Adam., Haifa, Palestine, det. Meyrick, British Museum, London.

The above listed data include the specimens recorded as marginella in the publications of Staudinger (Horae Soc. Ent. Ross. 15: I880), Skala (Ent. Z. 13: I929), Amsel (Veröff. Kolon. Mus. Bremen, 1: I935), Lhomme (Cat. Lep. France, 2: I939), Barraud (Entomologist, 56: I923). Some of these specimens were probably already mentioned in papers by Rebel. In addition to the above-mentioned publications there are the following records of marginella which also require verification: Lebanon-Zerny, Iris, 48: I934; Macedonia-Rebel and Zerny, Denkschr. Akad. Wiss. Wien, 103: I93I; Asia Minor-Rebel, Ann. naturh. Hofmus. Wien, 20: I906; Crete-Rebel, Ann. Naturh. Hofmus. Wien, 30: Igr6; Dalmatia-Rebel, Jber. Wien. Ent. Ver. 24: I9I4; Switzerland-Vorbrodt, Iris, 45: I93I ; and Müller-Rutz, Schmett. Schweiz, 2: I9I4. It is almost certain that the specimens determined as marginella and recorded in these publications are also erroneously named and have nothing to do with genuine Capperia marginella Zeller. It seems that marginella is endemic to Sicily, and this is an additional reason why the records of marginella from elsewhere are rather doubtful. For the time being one can accept the data from catalogues based on Zeller's publications only. However, neither those data nor Zeller's records of marginella refer exclusively to this species since Zeller included under this name some other species (see zelleri, celeusi, hellenica). Zeller in his descriptions gives differences between marginella and obscurus (= parvidactylus); but the characters he gives are generic and are not sufficient for distinguishing marginella from allied species of Capperia. The depth of the incision in the fore wings of marginella reaches nearly the middle of wing, as stated in Zeller's description, but in other species of Capperia, unknown to Zeller, the same feature appears. Another character of marginella given by Zeller is size and the colour of the spots in the cilia, but these vary considerably within a species and it is possible even to find specimens from two distinct species of Capperia with the spots in their cilia matching in pattern and colour. In Zeller's opinion marginella of southern Europe was the species which had become established and replaced parvidactylus, the latter species taking up a more northerly distribution. But in the light of further information it would now appear that his observations should be interpreted as the relationship between the genera Capperia and Oxyptilus and not to the two species, marginella and parvidactylus, alone.

Zeller described (I847) three females ${ }^{I}$ (from Syracuse) 4, 4, 23 May I843, ${ }^{2}$ and one male from Catania (4 July), but only the specimens from Syracuse are genuine

I There was only one female in this number, as the examination revealed.

2 The exact date of capture was not mentioned by Zeller, but was given by Frey (Stettin. Ent. Ztg. 1883: 4I5). 
marginella. The specimen from Catania appears to be a different species (see Capperia zelleri). The specimen from Asia Minor (Macri) mentioned by Zeller in his description of marginella was different too (see Capperia hellenica). I could not find in Zeller's collection the specimen from Brussa (Asia Minor) recorded by him as marginella, but it is certainly another erroneous determination.

In external appearance $C$. marginella approaches to $C$. celeusi, but its copulatory apparatus is quite different. It is a medium-sized species of its genus. The wing spread I5-I7 mm., female I6 mm. The colour of the wings is dark chocolate-brown. It seems to be darker than celeusi because the white pattern on the wings and on cilia is weaker. The tuft of scales on the third feather of secondaries is similar to that in celeusi.

Male copulatory apparatus. The aedeagus is strongly sclerotized, strongly curved like an 'S' and bilaterally asymmetric. The top part of aedeagus ends with the plate rounded on one side and having three broad teeth separated by the shallow incisions on its other side. The valva is strongly sclerotized, nearly straight, and narrows towards the base. The flap on the valva projecting inwards is long and pointed. The ninth tergum is pointed. The ninth sternum is strongly sclerotized, bifurcate, and with its two pointed ends nearly reaches the tips of the valvae. Female copulatory apparatus possesses a large plate covering the ostium bursae. This plate is very regular and symmetrical and shaped like a shield.

The early stages and food-plant are unknown.

Geographical distribution. Sicily; there are only three specimens known, all collected by Zeller.

\section{I4. Capperia zelleri, sp.n.}

$$
\text { (P1. 9, figs. 3, 3a) }
$$

Pterophorus marginellus sp.n. Zeller, r847, Isis, 40: 903-904 (partim). Oxyptilus marginellus Z., Zeller, I852, Linn. Ent. 6: 355 (partim).

Examined material:

I. The male specimen (Holotype) from Zeller Coll., one of 'paratypes' of Zeller's marginella (British Museum, London): ' marginellus Z., Catan. 4 July'; 'Zeller Coll., Walsingham Collection r910-427'; 'Oxyptilus marginellus Z. o Sicily'; 'Capperia zelleri sp.n., Holotypus, S. Adamczewski det., praep. genit. nr. Ox. 89’.

The above-mentioned specimen is distinguished from the other paratypes of $\mathrm{Ca}$ peria marginella by its small size, lighter colour, and also by the time and place of capture. The wing spread is $\mathrm{I} 4 \mathrm{~mm}$. The ground colour of the fore wings is light brown with a yellowish tint. The external appearance resembles that of Procapperia croatica, but the white pattern of zelleri is less distinct and not so vivid as in croatica. Also in the cilia of the hind margin of the fore wing in croatica there exist very distinct back tufts which are almost completely absent in zelleri. Capperia zelleri resembles also hellenica in its external appearance, but possesses much more black scaling inside the incision of the fore wings than does hellenica.

Male copulatory apparatus. Aedeagus strongly sclerotized, strongly curved like an ' $S$ ', asymmetrical. The end part of the aedeagus asymmetrically flattened in the form of an irregular oval plate with numerous minute teeth on its larger end. Valva strongly 
sclerotized, arched, with the long and pointed flap projecting along the valva towards its base. The valva is twice as wide at its end as in basal part. The ninth tergum is pointed. The ninth sternum similar to that in marginella, with its two pointed ends reaching the tops of the valvae. The female unknown.

The early stages and food-plant are unknown.

Geographical distribution. Sicily. Only one specimen known.

\section{I5. Capperia polonica, sp.n.}

Examined material:

$$
\text { (Pl. 9, fig. I; Pl. II, fig. I7; Pl. I7, fig. 42) }
$$

I. Holotype, male specimen from Sardinia (Mus. Zool. Polon. Collection, Warsaw): 'Aritzo, Sardegna, I4.vi.r933, Amsel'; 'Capperia polonica sp.n., Holotypus, ô, praep. genit. no. Ox. 85'.

2. Allotype, female specimen from Asia Minor (Mus. Zool. Polon. Coll., Warsaw): 'Turcia, ins. Büyük Ada ad Istanbul, 9-I I.vii.I938, leg. S. Adamczewski’; Capperia polonica sp.n., Allotypus, ㅇ, praep. genit. no. Ox. II5'.

3. Paratype, male specimen from Sardinia (Kolon. Mus. Collection, Bremen): 'Aritzo, Sardegna, I4.vi. I933, Amsel'.

4. Thirty-three paratypes, ôt 옹 from Asia Minor (Mus. Zool. Polon. Coll., Warsaw): ‘Turcia, ins. Büyük Ada ad Istanbul, 9-II.vii.r938, leg. S. Adamczewski' (praep. genit. ô nos.: Ox. II3, Ox. II4).

This is an intermediate-sized Capperia species. The specimens of the spring generation from Sardinia have a wing spread $18 \mathrm{~mm}$. The specimens of the summer generation from Asia Minor are smaller, I4-I6 mm. The ground colour of the wings is dark brown. The white pattern on the wings and cilia is strongly developed. The black pattern strongly contrasts with the white, giving this species a more variegated and lighter brown-coloured appearance than allied species. The specimens from Asia Minor have a little more black in the spot of scales of the third feather than the specimens from Sardinia.

Male copulatory apparatus. Valva slightly arched, twice as wide at the end as at its base. The flap on the valva projects along the valva towards its base; it is narrow and pointed. The ninth tergum elongated and blunt posteriorly. Two pointed ends of the bifurcate ninth sternum reach the tops of the valvae. The aedeagus is strongly sclerotized, strongly curved like an ' $S$ ', and asymmetrical. The end part of the aedeagus asymmetrically and bilaterally flattened in the form of a plate resembling a three-fingered paw of which the central finger is much longer than the lateral ones. The edge of this plate between the fingers weakly toothed. There are some individual differences to be found here. For example, some males from Asia Minor are toothed like the holotype from Sardinia, i.e. on one side of the central finger only (Ox. II3); another specimen from the same locality is toothed on both sides (slide no. Ox. II4).

The female copulatory apparatus is similar to that of marginella. Lamella antevaginalis and postvaginalis exhibit the large, strongly sclerotized shield of very regular shape resembling a triangle with rounded corners. On this shield is distinctly visible the wavy cut-out margin of the lamella antevaginalis.

The early stages unknown. 
The imagines of polonica were captured by disturbing them in places overgrown with Teucrium in the thin forest of pine, or flying around Teucrium, and at rest on this plant at sunset. The food-plant of polonica belongs to the group of closely related species of Teucrium allied to Teucrium chamaedrys L. At this time these plants were in flower and resembled very much the flowering plants of Teucrium chamaedrys which I observed in the Dniestr valley. Unfortunately the herbarium containing these plants was destroyed during the war before a more accurate determination could be made.

Geographical distribution. Sardinia and Asia Minor (Prinkipo Is.).

\section{I6. Capperia maratonica, sp.n.}

Examined material:

(P1. I6, figs. 34, 38, 39, 40)

I. Holotype, male specimen from Greece (Mus. Zool. Polon. Collection, Warsaw): 'Graecia, Kato Suli ad Maraton (Athinai), I6-r7.vii.r938, leg. S. Adamczewski'; 'Holotypus, ô, praep. genit. no. Ox. II2, C. maratonica Adam.'

2. Allotype, female specimen from Greece (Mus. Zool. Polon. Collection, Warsaw): 'Graecia, Kato Suli ad Maraton (Athinai), I6-17.vii.r938, leg. S. Adamczewski'; 'Allotypus, 오, praep. genit. no. Ox. II I, C. maratonica Adam.'

3. Thirteen paratypes, 호 우, from Greece (Mus. Zool. Polon. Collection, Warsaw): 'Graecia, Kato Suli ad Maraton (Athinai), r6-I7.vii.r938, leg. S. Adamczewski'.

4. Male specimen from Palestine (British Museum, London): 'Haifa, Palestine, I4.6.I920, P. J. Barraud, I920-347'; 'Oxyptilus parvidactylus Haw., teste Meyrick 37I'; 'I947/8' (praep. genit.).

5. Female specimen from Palestine (British Museum, London): 'Haifa, Palestine, 20.5.I920, P. J. Barraud, 1920-347'; 'Oxyptilus marginellus Zell., teste Meyrick 287'; 'I947/I3 (praep. genit.).

6. Female specimen from Palestine (British Museum, London): 'Haifa, Palestine, 2r.6.1920, P. J. Barraud, I920-347'; 'Sphenarches caffer Zell., teste Meyrick, 369'; ' I947/59' (praep. genit.).

7. Female specimen from Croatia (Magyar Nemzeti Muzeum, Budapest): 'Dr. Hensch, Krapina Cro.'; 'Praep. genit. no. Ox. . . .'

This is a medium-sized species of Capperia. The wing spread of the specimens from Palestine is $\mathrm{I} 4 \mathrm{~mm}$., and those from Greece $\mathrm{I} 4-\mathrm{I} 6 \mathrm{~mm}$. The ground colour of the wings is dark brown. The external appearances of the allotypes of maratonica and marginella were carefully compared because of the similarity of their genitalia. $C$. maratonica is smaller and more delicately built than marginella. The wing feathers seem to be narrower in maratonica. The light pattern on wings in both species is white but more defined in maratonica. The dark scales reach the apex of the third feather of the secondaries in maratonica (as in celeusi), while in marginella the dark scales of the spot of scales do not reach the apex of the third feather. These small differences may be due to seasonal dimorphism, since the allotype of maratonica was captured in July while that of marginella belonged to the spring generation.

Male copulatory apparatus. The valva is as in $C$. fletcheri, strongly curved and twice as broad at the posterior part as at the base. The flap on the valva projects towards its base and is wide and bluntly cut at the end. The aedeagus is strongly curved like an ' $S$ '. The end part of aedeagus is bilaterally flattened in the form of a plate ending with three large teeth. This plate is nearly symmetrical, a feature 
which is in contrast with the allied species, for example, lorana, marginella, zelleri, polonica, fletcheri, each of which has an asymmetrical aedeagus. The ninth tergum is elongated and ends with a pointed process. The ninth sternum is slender, bifurcate, and its two pointed ends extend to the ends of the valvae.

The female copulatory apparatus is of similar form to that of marginella. There is also the large shield covering the ostium bursae, but its construction is a little different. The fore margin of this plate shows some variability. The allotype (slide no. Ox. III) and one of the Palestine specimens (no. I947/I3) have a small depression in this place, while the other specimen from Palestine (no. I947/59) has the fore margin of the shield evenly rounded. The posterior part of eighth sternum in maratonica is more strongly sclerotized and darker than the corresponding part in marginella which is weak, membranous, and without such strong sclerotization.

The early stages and the food-plant are unknown.

C. maratonica appears in two generations and doubtless the larvae feed on a plant belonging to the Labiatae. The several specimens from Greece were all captured amongst weeds growing along the edges of ditches on the marshes near Kato Suli. If I remember correctly, amongst these plants were represented the genera Mentha, Marrubium, Veronica, and Carex. Unfortunately all herbarium material was destroyed during the war before the determinations could be made.

Geographical distribution. Greece (Attica), Yugoslavia (Croatia), Palestine.

\section{I7. Capperia fletcheri, sp.n.}

(P1. 9, figs. 4, 4a; Pl. II, fig. I6)

Oxyptilus marginellus Z., Amsel, 1935, Veröff. Kolon.-Mus. Bremen, 1: 258 (partim).

Examined material:

I. Holotype, male specimen from Palestine (Kolon. Mus. Collection, Bremen) : 'Kirjat-Anavim, Jerusalem, 2.v.1930, leg. H. G. Amsel ' ; 'Praep. genit. no. Ox. 84.' (Rebel det. : marginellus Z.).

This is one of the two specimens recorded by Amsel from Palestine as marginella (for another specimen see $C$.tamsi). These specimens were not labelled with the name of determinator. Dr. J. Kremky informs me that Dr. Amsel determined his materials from Palestine in the autumn of 1930 himself; Dr. H. G. Amsel wrote me himself that they 'wurden mir in Wien als marginellus bestimmt'.

Capperia fletcheri is a medium-sized species of the genus Capperia. It is dark brown in colour. The wing spread $16 \mathrm{~mm}$. The type is unique and in very poor condition, badly rubbed and not suitable for describing.

Male copulatory apparatus. The aedeagus is strongly curved like an ' $S$ ' and strongly thickened in the basal part. The end part of aedeagus is bilaterally asymmetric, flattened in the form of a plate which ends with three sharp-angled flaps. The valva is strongly curved, the posterior part of it twice as wide as at the base. The membranous piece projects along the valva towards its base and ends with a short, wide, and rounded flap. The ninth sternum is very narrow, bifurcate, and reaches with its two pointed ends to the ends of valvae. The female is unknown.

The early stages and food-plant are unknown.

Geographical distribution. Palestine (Jerusalem). 
I8. Capperia geodactyla (Fuchs), I903

Oxyptilus geodactylus sp.n., Fuchs, 1903, Stettin. Ent. Ztg. 64: I5.

Oxyptilus geodactylus Fuchs, Meyrick, I910, Gen. Ins. 100: 7 .

Oxyptilus geodactylus Fuchs, Meyrick, I913, Lep. Cat. 17: 7 .

The type of geodactyla has not been examined as Fuchs's collection was dispersed amongst various collections and I am unable to locate it. There is a possibility that the original specimens of geodactyla exist in the collections of Hinneberg, of Caradja, or of the Natural History Museum in Wiesbaden, none of which I have examined. Provisionally I am of the opinion that the type of geodactyla belonged to the genus Capperia, but this cannot be confirmed until the types or topotypes are examined. Fuchs (I903) gives a very detailed description of geodactyla, pointing out the distinctness of this species from celeusi and its similarity to lorana. In Hinneberg's opinion (in litt., cited by Fuchs, I903) geodactyla is identical with celeusi, but we know that Hinneberg was not very familiar with this group and even confused Capperia celeusi with Oxyptilus parvidactylus (Adamczewski, I938). On the other hand, Fuchs was a reliable authority on the palaearctic Plume-moths; he distinguished $C$. lorana against the opinion of such an eminent authority as O. Hofmann. And so, not being able to find and examine any typical material of geodactyla, I presume it to be a good species and to have been correctly distinguished as such by Fuchs in I903. It is possible that the examination of geodactyla will show it to be identical with one of the later described species. In any case the description of Fuchs allows us to put geodactyla into genus Capperia.

According to the original description geodactyla is a rather small species. The wing spread is about $\mathrm{I} 4 \mathrm{~mm}$. (the length of the fore wing $7 \mathrm{~mm}$.). The colour grey with a yellow-brownish tint. The light pattern not pure white, but with the slight yellowish tint as in lorana and trichodactyla. The spot of scales on the third feather of secondaries is very weakly marked.

The early stages, habits, and food-plant are unknown.

Geographical distribution. Eriwan; Fuchs gives this Armenian locality without any additional data.

\section{Genus OxyptiLus Zeller, I84I. ${ }^{\mathrm{I}}$}

Generic type: Oxyptilus pilosellae Zeller, r84r.

Oxyptilus, Zeller, I84I, Isis, 34: 765 (partim).

Oxyptilus, Adamczewski, 1939, Ann. Mus. Zool. Polon. 13: 263 (partim).

The palpi with very prominent tuft of scales. The third feather of the hind wings with the spot of scales on its end. The lateral margin of the second lobe of the fore wings distinctly arched. On the end of abdomen very distinct tufts of hairs. The aedeagus tubular, weakly sclerotized, slightly arched, bilaterally symmetrical, not armed. The valva weakly sclerotized, built of two joints. The shorter, top segment is placed on the end of the basal segment, which is usually much

I The genera Oxyptilus $\mathrm{Z}$. and Crombrugghia Tutt are taken into account only roughly here because all the relevant materials were destroyed during the war. The present outline should be regarded as the basis for further studies on these genera. In continuation some data are inserted about the nearest related but phylogenetically distinct group Trichoptilus sensu lato. This group of genera should be also carefully revised and separately elaborated. For the initiation of this work data concerning the Trichoptilus group, collected during the study of the Oxyptilus group, are added at the end of this systematic section. 
longer. Bursa copulatrix with a signum. The species belonging here appear in a single generation and they are oligophagous, but feed on the plants of the family Compositae only.

The following species belong here:

I. Oxyptilus pilosellae Zeller, I84I, which is the generic type.

2. Oxyptilus ericetorum Stainton, I85I (= ericetorum Zeller), described for the first time by Stainton (I85I, Suppl. Cat. Brit. Tin. Pter., Appendix: 28). His description was based on the original continental specimens received from Mann, and previously determined by Zeller. These specimens exist in the British Museum and both have the same labels: '27', 'I22', 'Stainton Coll., Brit. Mus. I893-I34', 'Pterophorus ericetorum Z., teste Stainton'. The first description by Zeller of ericetorum appeared after Stainton's publication in 1852 .

3. Oxyptilus chrysodactylus Denis et Schiffermüller, I775 (= hievacii Zeller). This name was lost and completely forgotten in lepidopterological systematics. It belongs to the species described by Zeller (I84I) for the second time as hieracii. The first description was very laconic and partially inaccurate because instead of the definition 'metallic shining bands' the incorrect expression 'gold shining' was used. Zeller's commentary (I84I) on the original specimens from Vienna made it possible to fix the proper systematic position for 'Phalaena Alucita chrysodactyla, W.V.' as the same as hieracii Z. (see above: Capperia trichodactyla D. \& S.).

4. Oxyptilus parvidactylus Haworth, I8II (= obscurus Zeller). This species, of variable colour, occurs in central Europe (Poland) in three forms living in different biotopes. They are a greyish-brown form from Podolia, an olive-brown form from Carpathian region, and a dark chocolate-brown form from the sandy plains of middle Poland. The systematic position of these forms needs further investigation. The appearance of this species in southern Europe and in the Middle East countries (from which it has been recorded) is also uncertain, because of its great similarity to some forms in the group of Oxyptilus hoffmannseggi. These matters need further study.

5. Oxyptilus hoffmannseggi Möschler, I866. This species is sometimes confused with some Capperia species (see above: Capperia tamsi). There exists a group of forms in the Mediterranean countries which vary in their size and colour. Their systematic position is not yet completely clear.

6. Oxyptilus bohemanni Wallengren, I862. This is a very little known northern European species recorded from Sweden and Holland. It is of the same size as chrysodactylus and differs from all other Oxyptilus species in its very characteristic colour. It is uniformly light brown in colour, almost without pattern. The only traces of pattern are present in the form of a slight paling of the ground colour on the fore wings in places.

7. Oxyptilus delawaricus Zeller, I873. This is the only species of the genus Oxyptilus known from the Northern American region.

\section{Genus Crombrugghia Tutt, I907}

Generic type: Oxyptilus distans Zeller, I847.

Oxyptilus, Zeller, I84I, Isis, 34: 765 (partim).

Crombrugghia, Tutt, I907, Brit. Lep. 5: 449-45I.

Oxyptilus, Adamczewski, 1939, Ann. Mus. Zool. Polon. 13: 263 (partim). 
The palpi with prominent tuft of scales. The spot of scales on the third feather of the hind wings very far placed from the tip of the feather (from one-third to the half of the length of the feather). The lateral margin of the second lobe of the fore wings distinctly arched. On the end of the abdomen there are present very distinct tufts of hairs. The aedeagus tubular, weakly sclerotized, slightly arched, bilaterally symmetrical, not armed. Valva weakly sclerotized, built of two long segments, which are usually of nearly the same length. The top segment is placed on the end of the basal one. Bursa copulatrix with a signum. The species belonging here appear in two generations a year. They are oligophagous but feed on the plants from the family Compositae only.

The following species belong to the genus Crombrugghia:

I. Crombrugghia distans Zeller, I847, which is the generic type. It is a very variable species in size and colour. It has several forms, especially in southern Mediterranean countries. These forms are often confused with the related species laetus and lantoscanus. In the cooler central European area it is confused with tristis. The taxonomic value of all these forms needs revision and the ecological data should be taken into account. The high-mountainous form approaching distans is very interesting and most probably a distinct species. This form was observed for the first time in Poland in July 1937 in Kobaki, district Kosów Pokucki, in the East Carpathian Mts. This Polish specimen was of the size of a central European distans, pale, greyishbrown, less reddish, and a little larger than the specimens of distans from the plains in Poland. The main difference from distans was in its tuft of scales of the third feather, which is placed near its end nearly as in the species of Oxyptilus. Similar specimens from Switzerland (Saas, 6,000-7,000 feet) are present in Meyrick's collection, erroneously named as 'heterodactyla Vill.' (see Pl. I2, fig. 64). Also in Walsingham's collection (British Museum) there exist similar specimens from Alpes-Maritimes (6,00o feet) named as distans. The specimens recorded by Frey (I880) from Swiss Alps (6,700 feet) under the name distans probably belong to the same form.

2. Crombrugghia laetus Zeller, I847. This is a Mediterranean species very often confused with the preceding one. It is not easy to fix the systematic position of this species because Zeller's type is not in the British Museum.

3. Crombrugghia lantoscanus Millière, I883. This species is known from southern France only. It is distinguished from larger and lighter coloured specimens of distans by the vivid yellow ground colour of its fore wings.

4. Crombrugghia tristis Zeller, I839. This is the smallest species in this genus. It is greyish, light-brown coloured. It lives in central Europe in sandy places overgrown with Hieracium. It is recorded also from some Mediterranean countries, but these records should be verified.

5. Crombrugghia kollari Stainton, I85I. This is an Alpine species a little larger than tristis. It is very characteristically grey-whitish coloured, some specimens being almost white.

\section{Generic group TRICHOPTILUs sensu lato}

The generic group most nearly related to Oxyptilus commonly passes as the genus Trichoptilus Walsingham. In this genus about thirty-five species have been described. Most of them were described by Meyrick, who erroneously synonymized Trichoptilus ENTOM. I, 5 . 
with the generic names Stangeia and Buckleria, distinguished by Tutt. Tutt (I907) erected these two genera for the European species siceliota Zeller and paludum Zeller. Amsel (I935) described in this group the genus Megalorrhipida for specimens of defectalis Walker from Palestine erroneously considered by him as a new species. However, this new generic name deserves to be kept in the systematics. In the group Trichoptilus s.l. as in the related group Oxyptilus s.l., there exist several, quite separate, evolutionary lines which are distinguished from one another by their morphological characters as well as by their geographical distribution and origin. The species defectalis Walker, very widely distributed as it is along the Equator, is the most primitive form in the group. Like the genus Sphenarches in the Oxyptilus group, defectalis possesses the most primitive structure of the copulatory apparatus in the group Trichoptilus. This species cannot be left in the genus Trichoptilus and the generic name Megalorrhipida may be accepted for defectalis. The generic type for the genus Trichoptilus Walsingham is the North American species Trichoptilus pygmaeus Walsingham, which has the well-developed tuft of scales on the third feather, valva well specialized, but not divided by joints, and aedeagus straight, slightly sclerotized (see P1. I2, fig. 63). In this genus, of course, there is no place for paludum or siceliota. These two species are the representatives of two Euro-Indo-Australian genera Buckleria and Stangeia and are completely different both in structure and origin from the American genus Trichoptilus. The genus Buckleria Tutt has a weakly sclerotized and nearly straight aedeagus and the valva also weakly sclerotized and divided by joints. It takes the place in the group Trichoptilus corresponding with the place of the genus Oxyptilus Zeller in the group Oxyptilus s.l. A very strongly sclerotized and very specialized copulatory apparatus characterizes genus Stangeia Tutt. It corresponds to the genus Capperia in the preceding group. It has the valvae formed like very strong hooks, strongly curved. The aedeagus very strongly built, strongly sclerotized, armed with processes and asymmetrical horns at its end (see P1. I2, fig. 62). These two genera call for redescription and placing afresh in the systematics of the generic group Trichoptilus s.l. I have not examined all the species belonging to this group and for that reason I do not know whether all its species could be placed in the four genera mentioned above. Probably it will be necessary to describe some further genera in this group especially for some American forms.

\section{SUMMARY}

The study of the generic group Oxyptilus s.l. is the subject of the present publication. This group contains six genera and forty-five species representing all the faunal areas. One new genus and nine new species are here described. Some forms from the generic group Trichoptilus s.l. have been partially taken into account for comparison. The group Oxyptilus is systematically revised on the basis of an analysis of its morphological characters. The group is formed of three smaller groups with two genera in each, namely, (I) Sphenarches-Geina, (2) Capperia-Procapperia, (3) Oxyptilus-Crombrugghia. Taxonomic analysis has shown that the synonymy found in this group by Meyrick was inconsistent. He distinguished the genus Sphenarches, but put into synonymy the genus Geina showing much larger morphological 
specialization than Sphenarches. He also included genus Geina in the completely different genus Oxyptilus, though Geina is nearly related to Sphenarches which Meyrick had described himself.

Besides the morphological characters all the available ecological and distributional data have been comparatively examined. Special attention has been paid to the usefulness of ecological and zoogeographical data as complementary biosystematic features. It is proved that the forms in the group discussed arranged according to their biosystematic features correspond to the new systematic order based on the synthesis of the morphological characters. It is highly probable that a similar revision of the taxonomic value of systematic features made amongst other groups of insects would show a similar coincidence of the biosystematic and morphological features. It seems to be the best way to reveal the genuine systematics existing in nature.

The comparative analysis of all morphological and biosystematic characters leads to the opinion that in the Oxyptilus group there exist representatives of several differing evolutionary lines, derived from a common ancestor. The correlation of these findings with the thesis of the Taylor-Wegener theory of continental drift gives an opportunity for the reconstruction of the history of speciation in these evolutionary lines and provides an explanation of any particular geographical distribution. In this way one can also define the age of any evolutionary line in spite of the absence of fossils in this group. The analysis of all these data provides evidence that the ancestral form common to all these lines in the group under discussion is a still living form, the evolution of which ceased, and which has continued to exist in some areas since the Cretaceous. This' may seem to be a very strange suggestion, but in the presence of the known facts, the author cannot find any other alternative explanation of the existing data. Sphenarches anisodactylus Walker is this ancestral form, very characteristic in its very primitive morphological and biosystematic features. This species has endured without any evolutionary changes for sixty million years in tropical territories where climatic conditions have not changed since the Cretaceous. One can find examples of checked speciation in other groups also, in which some fossils of recently living forms are found. Certain species of insects found in the Oligocene amber constitute similar existing proofs. The present wide distribution of Sphenarches anisodactylus and its presence on the islands and continents geographically isolated can only be explained along these lines. However, in some other regions the influence of climatic and other changes has resulted in the reactivation of the evolutionary ability in anisodactyla and initiated then new evolutionary lines in various territories and at various periods. The representatives of these lines are located in the genus Sphenarches or in the derivative genera of the Oxyptilus group according to their age and to the grade of modification of their morphological and biosystematical characters.

\section{Io. BIBLIOGRAPHY}

Adamczewski, S. I938. Suppléments et rectifications à la faune lépidoptérologique de la Pologne. Fragm. Faun. Mus. Zool. Polon. 3: 235-239.

- 1939. On the distinctness of the genera Oxyptilus Zeller and Capperia Tutt (Lepidoptera). Ann. Mus. Zool. Polon. 13: 259-268. 
Amsel, H. G. I935. Neue palästinensische Lepidopteren. Mitt. Zool. Mus. Berl. 20: 271-319, pls. 9-18.

— 1940. Über alte und neue Kleinschmetterlinge aus dem Mittelmeer-Gebiet. Veröff. Deutsch. Kolon.-Mus. Bremen, 3: 37-56, pl. 3.

Antevs, E. I928. The Last Glaciation, \& $c$. $\mathrm{x}+292$ pp., 9 pls. New York.

ARLDT, T. I936-1938. Die Entwicklung der Kontinente und ihrer Lebewelt, \&c. Zweite Auflage, Bd. 7, pt. I, I936; pt. 2, 1938. Berlin.

Barnes, W., \& Lindsey, A. W. I921. The Pterophoridae of America north of Mexico. Contrib. Nat. Hist. Lep. N. Amer. 4: 279-482, pls. 4I-54.

Bartholomew, J. G., Clarke, W. E., \& Grimshaw, P. H. igi i. Atlas of Zoogeography. London.

Beirne, B. P. I943. The distribution and origin of the British Lepidoptera. Proc. R. Irish Acad. 49 (B) : 27-59.

- I943. The relationships and origins of the Lepidoptera of the outer Hebrides, Shetlands, Faroes, and Iceland. Proc. R. Irish Acad. 49 (B): 9I-IoI.

Blackmore, E. H. I922. The Pterophoridae of British Columbia. Rep. Prov. Mus. Nat. Hist. Victoria, B.C. 1921: $34-45$, pls. V-VI.

Braun, A. F. I9I4. Evolution of the colour pattern in the Microlepidopterous genus Lithocolletis. J. Acad. Nat. Sci. Philad. 16: I05-I68, pls. III-IV.

Brinkmann, A., \& Amsel, H. G. I936. Über Bremer und nordwestdeutsche Kleinschmetterlinge. Mitt. ent. Ver. Bremen, 23 (I935): 8-20.

CARAdja, A. I920. Beitrag zur Kenntnis der geographischen Verbreitung der Microlepidopteren des paläarktischen Faunengebietes nebst Beschreibung neuer Formen. III. Iris, 34: 75-I 79 .

Charpentier, T., \& Zincken, J. L. T. F. I821. Die Zinsler, Wickler, Schaben und Geistchen des 'Systematischen Verzeichnisses der Schmetterlinge der Wiener Gegend' verglichen mit den in der Schiffermillerschen Sammlung in Wien befindlichen und von J. Hübner in seinem grossen Kupferwerke abgebildeten Arten dieser Gattungen, \&. c. xvi+i 78 pp. Braunschweig.

Chrétien, P. 1922. in C. Oberthür: Les Lépidoptères du Maroc. Étud. Lép. 19 (I): I3-403, pls. 74-I24.

Corbett, G. H., \& Gater, B. A. R. I926. A preliminary list of food-plants of some Malayan insects. Bull. Dep. Agric. F.M.S. 38.

Crombrugghe de Picquendaele, G. igoi. Note sur quelques Microlépidoptères de la faune Belge. Ann. Soc. Ent. Belg. 45: roo-ro4; also Rev. Soc. Ent. Namur, 4: 44-48, 1900.

1906. Catalogue raisonné des Microlépidoptères de Belgique. Mém. Ent. Soc. Belg. 13: I-I $72 ; 14:$ I-I 55 .

DE Geer, C. I77I. Mémoires pour servir à l'histoire des insectes, 2. Stockholm.

Denis, J. N. C. M., \& Schiffermüller, J. I775. Ankündigung eines systematischen Werkes von den Schmetterlingen der Wienergegend. 322 pp., 2 pls. Wien.

— I776. Systematisches Verzeichniss der Schmetterlinge der Wienergegend. 322 pp., 2 pls. Wien.

Duponchel, P. A. J., I838--I840. Histoire naturelle des Lépidoptères ou Papillons de France. (Nocturnes) 8. Paris.

- I844-1845. Catalogue méthodique des Lépidoptères d'Europe, Éc. $\mathrm{xxx}+523$ pp. Paris.

Du ToIT, A. L. I937. Our wandering continents. An hypothesis of continental drifting. xiii +366 pp. London.

Fernald, C. H. I898. The Pterophoridae of North America. Rep. Mass. Agric. Coll. 35: 83-162.

Fletcher, T. B. I9Io. Lepidoptera, exclusive of the Tortricidae and Tineidae, with some remarks on their distribution and means of dispersal amongst the islands of the Indian Ocean. Trans. Linn. Soc. Lond. Zool. 13: 265-323, pl. I7.

- 1920. Life-histories of Indian Microlepidoptera. Rep. Proc. Third. Ent. Meeting Pusa, 1919: $838-857$.

- I921. Life-histories of Indian Insects. Microlepidoptera. Mem. Dep. Agric. India Ent. $6(\mathrm{I}-9)$.

I926. On Walker's types of Plume-moths in the National Collection: redescriptions and notes. Trans. Ent. Soc. Lond. 1925: 599-639. 
Fletcher, T. B. 1929. A list of the Generic Names used for Microlepidoptera. Mem. Dep. Agric. India Ent. 11.

I931. Alucitidae. Cat. Ind. Ins. 20.

- 1938. Names of Microlepidoptera. Ent. Rec. 50: 77-78.

Frey, H. 1856. Die Tineen und Pterophoren der Schweiz. xii +430 pp. Zürich.

1880. Die Lepidopteven der Schweiz. xxvi+454 pp. Leipzig.

I886. Einige Micros aus Regensburg. Stettin. Ent. Ztg. 4\%.

Fuchs, A. I895. Kleinschmetterlinge der Loreleygegend. Stettin. Ent. Ztg. 56: 21-52.

I897. Microlepidoptera der Loreleygegend. Stettin. Ent. Ztg. 58: 325-340.

- I903. Neue Kleinfalter des Mittelmeergebietes. Stettin. Ent. Ztg. 64.

HAGEN, H. A. I862-1863. Bibliotheca entomologica. 2 Bd. Leipzig.

Hemming, F. 1937. Hübner: A Bibliographical and Systematic Account of the Entomological Works of J. Hübner and of the supplements thereto, by C. Geyer, G. F. von Frölich, and G. A. W. Herrich-Schäfer, \&c. 2 vol. London.

Hofmann, O. I896. Die deutschen Pterophorinen. Ber. Nat. Ver. Regensburg. 5: 25-219, pls. I-3.

I898. Beobachtungen über die Naturgeschichte einiger Pterophoriden-Arten. Ill. Z. Ent.

3: 306-308; 339-342.

Hori, H. I93I. Studies on the Japanese Pterophoridae. I. On the genera Pselnophorus and Sphenarches. Bull. Sci. Fak. Terk. Kjuŝu Univ. 4: 253-266, pls. 9-1o.

- 1936. Studies on the Japanese Pterophoridae. III. On the genus Trichoptilus and notes on Platyptilia rhododactyla and Oidematophorus lithodactylus. Bull. Sci. Fak. Terk. Kjuŝu Univ. r: 73-9I, pls. I-2.

Horn, W. I935. Über entomologische Sammlungen. Ent. Beih. Berlin-Dahlem. 2.

—, \& Kahle, I. I935-I937. Über entomologische Sammlungen. Ent. Beih. Berlin-Dahlem. 2: I-I60; 3: I6I-296; 4: 297-536, pls. I-38.

HüBNER, J. I786-1790. Beiträge zur Geschichte der Schmetterlinge. 2 Bd. Augsburg.

- I793-I842. Geschichte europäischer Schmetterlinge. 462 pls. col. Augsburg.

- I796-I84I. Sammlung europäischer Schmetterlinge. 7 pt. and atlas of pls. Augsburg.

- I8I6-I826. Verzeichniss bekannter Schmettlinge. 43I pp. Augsburg.

- 1827. Anzeiger der im Verzeichnisse bekannter Schmetterlinge angenommenen Benennungen ihrer Horden, Rotten, Stämme, Familien, Vereine, und Gattungen. 72 pp. Augsburg.

Hutchinson, J. I926-1934. The Families of Flowering Plants, Éc. 2 pt. London.

Ihering, H., von. I927. Die Geschichte des Atlantischen Ozeans. vii +237 pp., 9 pls. Jena.

JeAnnel, R. I942. La Genèse des faunes terrestres. Éléments de biogéographie. viii + 5I 4 pp., 8 pls. Paris.

Kuznetzov, N. Y. I938. The arctic fauna of Eurasia and its origin. (A study based mainly on Lepidoptera.) Bull. Acad.Sci.U.R.S.S. 1938: 105-1 I5; Trav. Inst.Zool. Acad.Sci. U.R.S.S. 5: $\mathrm{I}-85$.

LAspeyres, J. H. I805. Kritische Revision der neuen Ausgabe des Systematischen Verzeichnisses von den Schmetterlingen der Wienergegend. II. Illiger's Magazin für Insektenkunde, 4: $\mathrm{I}-68$.

Le Danors, E. I938. L'Atlantique. Histoire et vie d'un océan. 290 pp., I6 pls. Paris.

Lномме, L. I939. Catalogue des Lépidoptères de France et de Belgique. 3: 173-307. Le Carriol一 Lot.

Lindsey, A. W. I922. Notes on distribution and synonymy of some species of Pterophoridae (Lepid.). Ent. News, 33: 21 I-2I3. 1924. Trichoptilus pygmaeus Wlgm. and the neuration of the family Pterophoridae. J. Sci. Labs. Denison Univ. 20: 187-192, pl. 20.

Linnaeus, C. I758. Systema Naturae, ... Editio decima, reformata, Tom. I, Regnum Animale. ii +824 pp. Holmiae.

I76r. Fauna Svecica, . . . Editio altera. [xlvi $]+578$ pp., 2 pls. Stockholmiae.

McDunnough, J. I923. Notes on Pterophoridae with descriptions of new species. Canad. Ent. 55: $85-87$. 
McDunnough, J. 1926. Pterophoridae (The list of Canadian Plume Moths). Rep. Ent. Soc. Ont. 25: $49-5$.

- 1927. Contribution towards a knowledge of our Canadian Plume Moths (Lepidoptera). Trans. Roy. Soc. Can., Sect. V, 21: 175-19o, pls. I-2.

I933. Notes on North American Lepidoptera with descriptions of new species. Canad. Ent. 65: 200-208.

— I935. Notes on early stages of certain Canadian Microlepidoptera. Canad. Ent. 6r: 68-78. Meyrick, E. I886. On the classification of the Pterophoridae. Trans. Ent. Soc. Lond. 1886: $\mathrm{I}-2 \mathrm{I}$.

I89o. On the classification of the Pyralidina of the European fauna. Trans. Ent. Soc. Lond. 1889: 429-492, pl. I5.

— I908. Notes and descriptions of Pterophoridae and Orneodidae. Trans. Ent. Soc. Lond.190\%: 47I-5II.

- I913. Pterophoridae, Orneodidae. Lepid. Cat. 1\%: I-44.

- I925. Wegener's Hypothesis and the distribution of Microlepidoptera. Nature, Lond. 115: $834-835$.

- 1927. Microlepidoptera. Insects of Samoa, 3 (2): 65-1 16. London: Trustees of the British Museum (Natural History).

1928. A revised Handbook of British Lepidoptera. vi+9i4 pp. London.

- 1935. List of Microlepidoptera of Chekiang, Kiangsu and Hunan. In Caradja and Meyrick's Mater. Microlep. Kiangsu: 44-96.

Möschler, H. B. I866. Aufzählung der in Andalusien I 865 von Herrn Graf v. Hoffmannsegg gesammelten Schmetterlinge. Berl. Ent. Z. 10: 136-146.

Müller-Rutz, J., \& Vorbrodt, K. I914. Die Schmetterlinge der Schweiz, 2: I-727. Berlin.

Murray, D. P. I942. On our plume moths. Trans. Suffolk Nat. Soc. 5: 7-1o, I pl.

Powell, H. I922. Addenda et corrigenda à la faune des Lépidoptères du Maroc. in Oberthür: Étud. Lép. Comp. 19: 8I-90.

Rebel, H. I9I4. Über eine Microlepidopterenausbeute aus dem westlichen Thian-Schan Gebiet. Iris. 28: 271-278.

— 1916. Beiträge zur Lepidopterenfauna Ungarns. Rovart. Lap. 23: 103-II9.

Reutti C., Meess, A., \& Spuler, A. I898. Übersicht der Lepidopteren-Fauna des Grossherzogtums Baden. Zweite Ausgabe. Verh. Naturw. Ver. Karlsruhe. 12.

RöSSler, A. I866. Verzeichniss der Schmetterlinge des Herzogthums Nassau. Jb. Nassau. Ver. Naturk. 1864-1866: I9-20; IOI-4I6.

I88I. Die Schuppenflügler des Kgl. Regierungsbezirks Wiesbaden und ihre Entwicklungsgeschichte. Jb. Nassau. Ver. Naturk. 1880-1881: 33-34; I-393.

Schleich, Dr. I 864 . Über die früheren Entwicklungsstände des Pterophorus didactylus Lin., Ev. (trichodactylus Hb.). Stettin. Ent. Z. 25: 96-98.

Schütze, K. T. I93I. Biologie der Kleinschmetterlinge. 235 pp. Frankfurt a./M.

Sorhagen, L. I886. Die Kleinschmetterlinge der Mark Brandenburg, \&c. x+368 pp. Berlin.

South, R. I88I-I889. Contributions to the History of the British Pterophori. Entomologist, 14-22.

Staudinger, O. I88o. Lepidopteren-Fauna Kleinasiens. Horae Soc. Ent. Ross. 15: I59-435.

Steudel, W., \& HofmanN, E. I882. Verzéichniss württembergischer Kleinschmetterlinge. Jh. Ver, vaterl. Naturk. Württemb. 38: $143^{-262}$.

Strand, E. I913. Zoologische Ergebnisse der Expedition des Herrn G. Tessmann nach SüdKamerun und Spanisch Guinea. IV. Arch. Naturgesch. "8: 143-262.

TAYLOR, F. B. I9Io. Bearing of the tertiary mountain belt on the origin of the earth's plan. Bull. Geol. Soc. Amer. 21: 179-226.

Tengström, F. M. F. I859. Anmärkningar och Tillägg till Finlands Småfjäril-Fauna. Bidr. Finl. Nat. Folk. 3: 155-226.

Treitschke, F. I833. Die Schmetterlinge von Europa. 9: I-294. Leipzig.

Tutr, J. W. 1907. A Natural History of the British Lepidoptera. 5. London.

Vester, H. I940. Die Areale und Arealtypen der Angiospermenfamilien. Bot. Arch. 41: I-I94. 
WALlACE, A. R. I90o. The Coleoptera of Madeira as illustrating the origin of insular faunas. In Studies Scientific and Social: 250-256. London.

Walsingham, Baron. I88o. Pterophoridae of California and Oregon. xvi +66 pp., 3 pls. London. I88r. On the Tortricidae, Tineidae and Pterophoridae of South Africa. Trans. Ent. Soc. Lond. 1881: 219-288, pls. Io-13.

I89I. In Cotes, E. C. Miscellaneous notes from the entomological section of the Indian Museum. Indian Mus. Notes, 2: I-48.

1897. Revision of the West-Indian Microlepidoptera, with descriptions of new species. Proc. Zool. Soc. Lond. 1897: 54-183.

I898. [A review of 'The Pterophoridae of North America', by C. H. Fernald, I 898.] Ent. Mon. Mag. 34: 190-I96.

WARNECKE, G. I9I9. Einige Skizzen zur Zoogeographie der Schmetterlinge Deutschlands. Iris, 33: 99-I05, 3 maps.

I935. Grundsätzliches zur Methodik zoogeographischer Untersuchungen in der Entomologie. Int. Ent. Z. 28: 46I-465.

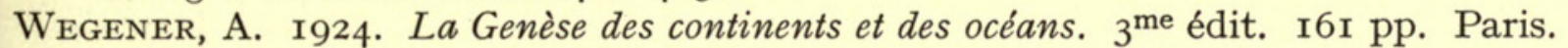

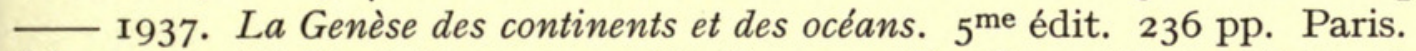

Whitcomb, W. D., \& Tomlinson, W. E. I940. The Grape Plume Moth. J. Econ. Ent. 33: 372374, I fig.

\& Guba, E. F. 1943. The Grape Plume Moth, with notes on other Pests of Grapes in Massachusetts. Bull. Mass. agric. Exp. Sta. 409: I-20, 6 figs.

ZelleR, P. C. I839. Kritische Bestimmung der in Degeers 'Abhandlungen zur Geschichte der Insekten' enthaltenen Lepidopteren. Oken, Isis, 32: col. 243-347.

I84I. Vorläufer einer vollständigen Naturgeschichte der Pterophoriden, einer Nachtfalterfamilie. Oken, Isis, 34: col. 755-794; 827-891.

I847. Bemerkungen über die auf einer Reise nach Italien und Sicilien beobachteten Schmetterlingsarten. Oken, Isis, 40: col. I2I-I59; 2I3-233; 284-308; 40I-457; 48I-522 ; $56 \mathrm{I}-594 ; 64 \mathrm{I}-673 ; 72 \mathrm{I}-77 \mathrm{I} ; 8 \mathrm{OI}-859 ; 88 \mathrm{I}-9 \mathrm{I} 4$.

1852. Revision der Pterophoriden. Linn. Ent. Berl. 6: 319-4I3.

I852. Lepidoptera Microptera quae J. A. Wahlberg in Caffrorum terra collegit. K. svenska Vetensk. Akad. Handl. 1852: I-I 20.

Zeuner, F. E. I935. The Pleistocene chronology of Central Europe. Geol. Mag. Lond. "72: $350-376$.

I943. Studies in the systematics of Troides Hbn. (Lep., Papilionidae) and its allies; distribution and phylogeny in relation to the geological history of the Australasian Archipelago. Trans. Zool. Soc. Lond. 25: 107-184.

I945. The Pleistocene period, its climate, chronology and faunal successions. $\mathrm{xii}+322 \mathrm{pp}$. London: Ray Society.

1946. Dating the Past. An Introduction to Geochronology. xviii+444 pp., 24 pls. London.

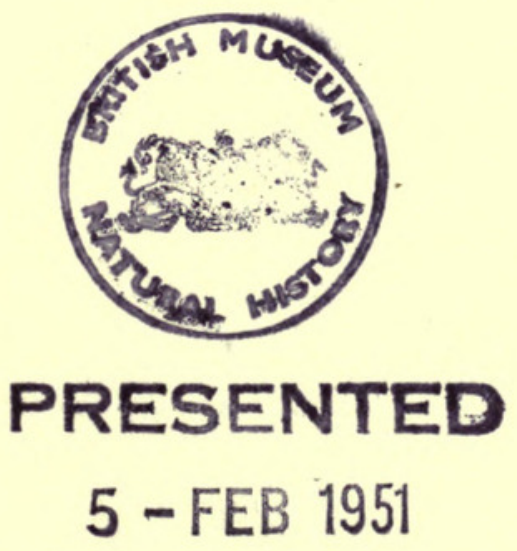





\section{$2 \mathrm{BHL}$ Biodiversity Heritage Library}

Adamczewski, S. 1951. "On the systematics and origin of the generic group Oxyptilus Zeller (Lep. Alucitidae)." Bulletin of the British Museum (Natural History) Entomology 1, 301-388. https://doi.org/10.5962/bhl.part.27232.

View This Item Online: https://www.biodiversitylibrary.org/item/19418

DOI: https://doi.org/10.5962/bhl.part.27232

Permalink: https://www.biodiversitylibrary.org/partpdf/27232

\section{Holding Institution}

Natural History Museum Library, London

\section{Sponsored by}

Natural History Museum Library, London

\section{Copyright \& Reuse}

Copyright Status: In copyright. Digitized with the permission of the rights holder.

Rights Holder: The Trustees of the Natural History Museum, London

License: http://creativecommons.org/licenses/by-nc-sa/4.0/

Rights: http://biodiversitylibrary.org/permissions

This document was created from content at the Biodiversity Heritage Library, the world's largest open access digital library for biodiversity literature and archives. Visit BHL at https://www.biodiversitylibrary.org. 